OPEN ACCESS

Edited by:

Salvador Cañigueral, University of Barcelona, Spain

Reviewed by:

Sameer Goyal,

R. C. Patel Institute of Pharmaceutical Education and Research, India Francisco Pérez García, University of Barcelona, Spain

${ }^{*}$ Correspondence: Shreesh K. Ojha shreeshojha@uaeu.ac.ae

Specialty section: This article was submitted to

Ethnopharmacology,

a section of the journal Frontiers in Pharmacology

Received: 14 February 2017 Accepted: 31 May 2017 Published: 26 June 2017

Citation:

Nagoor Meeran MF, Javed $H$, Al Taee H, Azimullah S and Ojha S (2017) Pharmacological Properties and Molecular Mechanisms of Thymol: Prospects for Its

Therapeutic Potential and Pharmaceutical Development.

Front. Pharmacol. 8:380

doi: 10.3389/fphar.2017.00380

\section{Pharmacological Properties and Molecular Mechanisms of Thymol: Prospects for Its Therapeutic Potential and Pharmaceutical Development}

\author{
Mohamed Fizur Nagoor Meeran', Hayate Javed², Hasan Al Taee', Sheikh Azimullah' \\ and Shreesh K. Ojha ${ }^{1 *}$
}

\begin{abstract}
'Department of Pharmacology and Therapeutics, College of Medicine and Health Science, United Arab Emirates University, Al Ain, United Arab Emirates, ${ }^{2}$ Department of Biochemistry, College of Medicine and Health Science, United Arab Emirates University, Al Ain, United Arab Emirates
\end{abstract}

Thymol, chemically known as 2-isopropyl-5-methylphenol is a colorless crystalline monoterpene phenol. It is one of the most important dietary constituents in thyme species. For centuries, it has been used in traditional medicine and has been shown to possess various pharmacological properties including antioxidant, free radical scavenging, anti-inflammatory, analgesic, antispasmodic, antibacterial, antifungal, antiseptic and antitumor activities. The present article presents a detailed review of the scientific literature which reveals the pharmacological properties of thymol and its multiple therapeutic actions against various cardiovascular, neurological, rheumatological, gastrointestinal, metabolic and malignant diseases at both biochemical and molecular levels. The noteworthy effects of thymol are largely attributed to its anti-inflammatory (via inhibiting recruitment of cytokines and chemokines), antioxidant (via scavenging of free radicals, enhancing the endogenous enzymatic and nonenzymatic antioxidants and chelation of metal ions), antihyperlipidemic (via increasing the levels of high density lipoprotein cholesterol and decreasing the levels of low density lipoprotein cholesterol and low density lipoprotein cholesterol in the circulation and membrane stabilization) (via maintaining ionic homeostasis) effects. This review presents an overview of the current in vitro and in vivo data supporting thymol's therapeutic activity and the challenges concerning its use for prevention and its therapeutic value as a dietary supplement or as a pharmacological agent or as an adjuvant along with current therapeutic agents for the treatment of various diseases. It is one of the potential candidates of natural origin that has shown promising therapeutic potential, pharmacological properties and molecular mechanisms as well as pharmacokinetic properties for the pharmaceutical development of thymol.

Keywords: thymol, antioxidant, free radical scavenger, cancer, animals, drug discovery, phytochemicals, natural compounds 


\section{INTRODUCTION}

Extensive epidemiological and experimental studies have suggested the health benefits of medicinal herbs as well as their constituents against various human ailments (Sofowora et al., 2013). The therapeutic importance of plants have been quoted in the ancient cultures and traditions of many countries and societies and they are believed to be cost effective and safe. Since ancient times, plants and their products are used as a culinary preparation or as a remedy in different traditional medicine for many diseases (Rahmani et al., 2014). Turmeric, oregano, thyme, olives and dates, to name a few, have been used extensively for culinary purposes in diets and are also believed to possess beneficial effects against numerous diseases (Rahmani et al., 2014). Among these spices, the Greeks, Romans, and Egyptians have used thyme as a preservative, odorant and flavoring agent in foods. It is a small subshrub abundantly used as a traditional medicine in the western Mediterranean region and its leaves are often used as herbal medicinal products and food additives (Zarzuelo and Crespo, 2002). Thyme possesses potent antibacterial, antifungal, sedative, antiseptic, antioxidative, expectorant, antispasmodic, antifungal, antivirotic, antihelminthic, carminative and diaphoretic effects (Rustaiyan et al., 2000; Soliman and Badeaa, 2002). Thyme contains abundant amount of terpenoids, flavonoids, glycosides and phenolic acids (Vila, 2002).

Among many constituents, thymol, chemically known as 2 -isopropyl-5-methylphenol is a dietary monoterpene phenol and is abundantly found in certain plants such as Thymus vulgaris (Amiri, 2012), Ocimum gratissimum (Pandey et al., 2014), Thymus ciliates (Kabouche et al., 2009), Satureja thymbra (Markovic et al., 2011), Thymus zygis (Ocana and Reglero, 2012), Trachyspermum ammi (Bairwa et al., 2012), Carum copticum (Khajeh et al., 2004), Satureja intermedia (Yousefzadi et al., 2012), Thymbra capitata (Miguel et al., 2015), Lippia multiflora (Ku and Lin, 2013), Thymus pectinatus (VardarUnlu et al., 2003), Zataria multiflora (Veras et al., 2013), Satureja hortensis (Soran and Lung, 2010), Centipeda minima (Liang et al., 2007) and Nigella sativa seeds (Ghosheh et al., 1999). Thymol possesses antibacterial (Didri et al., 1994), antifungal (Mahmoud, 1994), anti-inflammatory (Aeschbach et al., 1994), antioxidant (Yanishlieva et al., 1999), antimutagenic (Zahin et al., 2010), larvicidal (Pavela, 2009), analgesic (Ozen et al., 2011), anti-microbial (Karpanen et al., 2008), acaricidal (Araujo et al., 2015), anticonvulsant, antiepileptogenic (Sancheti et al., 2014), wound healing (Riella et al., 2012), antihemolytic (Alinezhad et al., 2013), antiphlogistic (Anamura, 1989), antileishmanial (Robledo et al., 2005) and radioprotective (Archana et al., 2011a) properties. Thymol improves digestion by relaxing smooth muscles, prevents menstrual cramps, attenuates respiratory problems and is an active ingredient used in food flavorings, topical ointments, various soaps, toothpastes, shampoos, deodorants and mouthwashes (Shapiro et al., 1994; Manou et al., 1998). Due to its potent antimicrobial properties, thymol is frequently used in dentistry for the treatment of oral cavity infections (Maruniak et al., 1992; Shapiro and Guggenheim, 1995; Twetman et al., 1995; Ogaard et al., 1997;
Khan et al., 2017). These pharmacological properties of thymol are ascribed to the pharmacophore of the phenolic hydroxyl group in its chemical structure. The compounds containing the phenolic groups are known to confer protection against the deleterious effects of free radicals both by absorbing or neutralizing free radicals and by augmenting endogenous antioxidants (Wojdylo et al., 2007).

Thymol is biosynthesized by the hydroxylation of $p$-cymene after the aromatization of $\gamma$-terpinene to $p$-cymene (Poulose and Croteau, 1978). The lethal dose $\left(\mathrm{LD}_{50}\right)$ value of thymol for rats and guinea pigs is $980 \mathrm{mg} / \mathrm{kg}$ and $88 \mathrm{mg} / \mathrm{kg}$, body weight, respectively (Jenner et al., 1964). For male and female ddY mice the $\mathrm{LD}_{50}$ is 1200 and $1050 \mathrm{mg} / \mathrm{kg}$, respectively (Hasegawa et al., 1989), whereas the $\mathrm{LD}_{50}$ for cats, rabbits and mice are $250 \mathrm{mg} / \mathrm{kg}$, $750 \mathrm{mg} / \mathrm{kg}$ and $640 \mathrm{mg} / \mathrm{kg}$, respectively (Instituto Superiore di Sanita, 1999). The time-tested safety and activity of thymol can also be attested to by the use of thymol for centuries in different cultures and civilizations. One example is the use of thymol containing herbs by the ancient Egyptians for the preservation of mummies. According to the Environmental Protection Agency, there are no known adverse effects with respect to thymol when used in animals and humans. Thymol is cataloged by the United States Food and Drug Administration as 'Generally Recognized As Safe' for use as a food additive, therefore it is considered to be safe with negligible toxicity.

An extensive literature survey has revealed some excellent reviews on essential oils regarding their phytochemical and pharmacological activities based on their various pharmacological properties. There is a short review describing the therapeutic and pharmacological effects of thymol (Parasei et al., 2016) and a detailed one presenting the antimicrobial properties of thymol (Marchese et al., 2016). But there are no reviews that have been published focusing on the multipharmacological properties of thymol against various human ailments until now. Thus, thist review aims to reveal the various pharmacological activities and therapeutic potential of thymol as well as prospects for its pharmaceutical development followed by its mechanism of action demonstrated in both in vivo and in vitro studies.

\section{Chemistry and Physical Characteristics of Thymol}

Thymol (2-isopropyl-5-methylphenol) is a white crystalline substance that gives thyme its strong flavor, pleasant aromatic odor and strong antiseptic property. Its density at $25^{\circ} \mathrm{C}$ is $0.96 \mathrm{~g} / \mathrm{cm}^{3}$ with a melting point ranging from $49^{\circ} \mathrm{C}$ to $51^{\circ} \mathrm{C}$ (322-324 K; 120-124 ${ }^{\circ}$ ) (Jordan et al., 1991; Lide and Frederikse, 1996). It is highly soluble in alcohols, alkaline solutions and other organic solvents due to the deprotonation of phenol but it is slightly soluble in water at neutral $\mathrm{pH}$ and it absorbs maximum UV radiation at $274 \mathrm{~nm}$ (Norwitz et al., 1986; Wade and Reynolds, 1997). It has low solubility in water and its unpleasant taste and smell makes it less palatable (Nieddu et al., 2014). It also has low solubility in the hydrophobic domain of the bacterial cytoplasmic membrane due to its hydrophobicity (Trombetta et al., 2005). For the past few decades, the synthesis of thymol has 
been achieved using the reaction between $p$-cymene and $m$-cresol with isopropyl alcohol or propene and by the use of supercritical $\mathrm{CO}_{2}$ (Amandi et al., 2005; Nagle et al., 2013). Thymol is an important agent of natural origin and has generated interest in the scientific community in pharmacological studies for its therapeutic potential in different diseases. The present review presents an overview of its preclinical data, pharmacokinetics, pharmacological properties and therapeutic potential in different human diseases.

\section{Pharmacokinetics of Thymol Absorption}

Previous reports have revealed the rapid absorption of thymol following oral administration and its degradation in the stomach or intestine (Michiels et al., 2008; Anderson et al., 2012). A report from Schroder and Vollmer (1932) has evidenced the presence of thymol in the stomach, intestine, and urine after its oral administration with sesame oil at a dose around $500 \mathrm{mg}$ in rats and $1-3 \mathrm{~g}$ in rabbits. A single dose of thymol (1 or $3 \mathrm{~g}$ ) encapsulated in gelatin capsule administered to dogs showed the presence of thymol conjugates in urine (22 or 34\%) after 3-4 $\mathrm{h}$ following urine and fecal analysis (Robbins, 1934). Oral administration of a single dose of thymol $(50 \mathrm{mg} / \mathrm{kg})$ was rapidly absorbed and slowly eliminated approximately within $24 \mathrm{~h}$ (Nieddu et al., 2014). The maximum concentration ( $\left.\mathrm{T}_{\max }\right)$ was reached after $30 \mathrm{~min}$, while approximately $0.3 \mathrm{~h}$ was needed for the half-life of the absorption phase $\left(t_{1 / 2}\right)$. The lower concentrations of thymol were recovered in the liver, lungs, kidneys, and muscles while its higher concentrations were detected in the mucosa and other inner contents of the intestines indicating its partial absorption (Nieddu et al., 2014). According to the report of Kohlert et al. (2002), after the intake of one Bronchipret $^{\circledR}$ TP tablet that is equivalent to $1.08 \mathrm{mg}$ of thymol, the plasma concentrations of thymol metabolites were detectable after $20 \mathrm{~min}$. The rapid absorption of thymol indicates that it's mainly absorbed in the upper component of the gut. In healthy volunteers, the oral administration of one Bronchipret ${ }^{\circledR}$ TP tablet resulted in a peak plasma concentration $\left(\mathrm{C}_{\max }\right)$ of $93.11 \mathrm{ng} / \mathrm{ml}$, $\mathrm{T}_{\max }$ of $1.97 \mathrm{~h}, t_{1 / 2}$ of $10.2 \mathrm{~h}$, area under time curve from time 0 to clast $\left(\mathrm{AUC}_{0} \rightarrow\right.$ clast of $837.3 \mathrm{ngh} / \mathrm{ml}$, mean residence time after extravascular administration $\left(\mathrm{MRT}_{\mathrm{abs}}\right)$ of $12.6 \mathrm{~h}$ and a mean absorption time (MAT) of $0.53 \mathrm{~h}$ (Kohlert et al., 2002). It also had a total body clearance of $1.2 \mathrm{l} / \mathrm{h}$, volume of distribution at steady state of $14.7 \mathrm{l}$ and a volume of distribution during the elimination phase of $17.7 \mathrm{~h}$ was reported in healthy humans (Kohlert et al., 2002).

\section{Distribution}

Free thymol is usually not detectable in human plasma. It is circulated as thymol sulfate, not glucuronide, in the blood stream as detected by liquid chromatography-mass spectrophotometry/mass spectrophotometry (LC-MS/MS). Thymol sulfate has been detected in plasma $20 \mathrm{~min}$ after administration. The maximum plasma levels $(93.1 \pm 24.5 \mathrm{ng} / \mathrm{ml})$ of thymol were reported after $1.97 \pm 0.77 \mathrm{~h}$ of administration. After administration the bioavailability of thymol measured in plasma as thymol sulfate was found to be about $16 \%$. It is eliminated by kidneys and is measured in the urine as thymol conjugates. The volume of distribution (Vdss/f) of $14.7 \mathrm{~L}$ has revealed that thymol sulfate mainly resides in the extracellular space (Kohlert et al., 2002).

\section{Metabolism}

Thymol undergoes glucuronidation by uridine 5 -diphosphoglucuronosyltransferase (UGT) following secretion into the proximal tubule (Raoof et al., 1996; Shipkova et al., 2001). The absence of thymol glucuronide in plasma could be due to the lower activity of hepatic UGT compared to sulfotransferase and the formation of glucuronide was shown only at much higher doses (Ogata et al., 1995). In healthy human volunteers, thymol $(0.6 \mathrm{~g} / \mathrm{kg})$ was metabolized to thymol sulfate, thymol glucronide and thymol thymohydroquinone sulfate and it was excreted in urine (Takada et al., 1979).

\section{Elimination}

The elimination of thymol conjugates in urine was detectable for the first $24 \mathrm{~h}$, with the majority being eliminated after $6 \mathrm{~h}$. The combined amount of both thymol sulfate and glucuronide excreted in urine during the first $24 \mathrm{~h}$ was $16.2 \pm 4.5 \%$ of thymol intake. The renal clearance was calculated to be $0.271 \pm 0.7 \mathrm{~L} / \mathrm{h}$ (Kohlert et al., 2002). Takada et al. (1979) studied the metabolism of thymol in rabbits and humans, wherein thymol $(0.5 \mathrm{~g} / \mathrm{kg})$ fed to rabbits metabolized to thymol glucuronide as the main metabolite of thymol and eliminated as glucuronic acid and sulfuric acid metabolites (Takada et al., 1979). Austgulen et al. (1987) reported the rapid excretion of thymol and its metabolites in the urine of male albino Wistar rats after thymol was dosed by gavage $(1 \mathrm{mM} / \mathrm{kg})$ as analyzed by capillary gas chromatographymass spectrometry (GC-MS). Williams (1959) summarized the previous reports on the metabolism of thymol and reported its excretion as sulfate and glucuronide conjugates in the urine of dogs, rats and humans. Around $1 \mathrm{~g}$ (one third) of the dose was excreted in the urine of dogs while feces were found to be devoid of thymol (Robbins, 1934).

\section{Pharmacological Properties of Thymol Antioxidant Properties}

The antioxidant properties of thymol have been well documented in various preclinical studies including cell lines and animal models. At high rate constants, it effectively scavenged the hydroxyl free radicals thereby producing major transient species named phenoxyl radicals. The generated adducts from the phenoxyl radicals undergo dehydration which can be accelerated by an alkaline medium. The addition of hydroxyl radicals at the ortho position (C6 atom) of the phenolic group yields the phenoxyl radical after dehydration. The attack at the ortho position is more favorable energetically while the attack at the para position is also expected to occur. Furthermore, additions at the ortho positions occur without any precomplex formation. The non-toxicity and redox potential of the thymolø/thymol couple makes it a promising antioxidant (Venu et al., 2013).

One of the most studied effects of thymol includes the scavenging of free radicals by increasing the activities of several endogenous antioxidant enzymes levels viz. superoxide 
dismutase (SOD), catalase, glutathione peroxidase (GPx), glutathione-S-transferase (GST) along with non-enzymatic antioxidants such as vitamin $\mathrm{C}$, vitamin $\mathrm{E}$ and reduced glutathione (GSH) (Nagoor Meeran and Prince, 2012). A comparative study revealed that thymol has superior reducing power, DPPH, superoxide and hydroxyl radical scavenging activity and bestows protection against oxidative damage to lipids (Nagoor Meeran et al., 2015b). The various supportive evidences for the antioxidant activity of thymol are detailed below.

\section{In Vitro Studies}

Thymol was shown to exhibit potent superoxide anion, hydroxyl and DPPH radical scavenging and reducing capacity in a concentration dependent manner (Nagoor Meeran and Prince, 2012; Nagoor Meeran et al., 2015b, 2016b). Thymol possesses SOD like activity in removing superoxide radicals in vitro (Kruk et al., 2000). It has also shown moderate antioxidant activity in V79 Chinese hamster lung fibroblast cells (Undeger et al., 2009). Thymol $(25 \mu \mathrm{g} / \mathrm{ml})$ showed potent antioxidant activity by modulating the activities of enzymatic antioxidants and decreased lipid peroxidation in gamma ray induced V79 Chinese hamster cells (Archana et al., 2011b). Thymol (0.02-0.20\%) showed better antioxidant capacity than its isomer carvacrol in lipid systems due to its greater steric hindrance and it was shown that at room temperature it inhibited the autoxidation of two lipid systems namely triacylglycerols of lard (TGL) and triacylglycerols of sunflower oil (TGSO). Furthermore, it also inhibited the oxidation of TGL and TGSO, with potent antioxidant activity against TGSO. Thymol increased chain initiation during the oxidation of TGSO more so than during the oxidation of TGL (Yanishlieva et al., 1999). In the intestinal Caco- 2 cell line, thymol $(250 \mu \mathrm{M})$ attenuated oxidative stress induced by hydrogen peroxide $\left(\mathrm{H}_{2} \mathrm{O}_{2}\right)$ (Cabello et al., 2015). Thymol $(250$ and $500 \mu \mathrm{M})$ strongly inhibited nicotinamide adenine dinucleotide phosphate reduced (NADPH)-cytochromec reductase mediated lipid peroxidation isolated from detergent solubilized liver microsomes of rats (Kamataki et al., 1978). Thymol attenuated the production of reactive oxygen species (ROS) and showed myeloperoxidase inhibitory activity in human neutrophils (Perez-Roses et al., 2016).

\section{In Vivo Studies}

Owing to its potent antioxidant potential, thymol showed radioprotective and anticlastogenic potential in gamma radiation induced Swiss albino mice (Archana et al., 2011b). Thymol supplementation increased the antioxidant status and decreased malondialdehyde (MDA) levels in broiler chickens (Zidan et al., 2016). Dietary supplementation with the combination of carvacrol-thymol (1:1) $(100 \mathrm{mg} / \mathrm{kg})$ reduced the occurrence of oxidative stress and the impairment of the intestinal barrier in weaning piglets by its potent antioxidant property (Wei et al., 2016). Thymol (24.7 mg/kg) attenuated aflatoxin-induced oxidative stress in male rats due to its potent antioxidant activity (El-Nekeety et al., 2011). Thymol (7.5 mg/kg) has been shown to inhibit lipid peroxidation, glycation, dyslipidemia, inflammation, ionic homeostasis malfunction and apoptosis by virtue of its potent antioxidant property (Nagoor Meeran and Prince, 2012; Nagoor Meeran et al., 2014, 2015b,c, 2016b).

\section{Anti-inflammatory Properties}

Thymol $(150 \mu \mathrm{M})$ has been shown to ameliorate LPS-induced inflammation in murine macrophage cell lines (Chauhan et al., 2014). Thymol (84 $\mu \mathrm{g} / \mathrm{ml})$ treatment attenuated lipopolysaccharide (LPS) and interferon gamma (IFN- $\gamma$ ) induced macrophage inflammation in vitro by inhibiting messenger RNA expression of inducible nitric oxide (NO) in J774A.1 cell lines (Vigo et al., 2004). In human polymorphonuclear neutrophils (PMNs), thymol (10 and $20 \mu \mathrm{g} / \mathrm{ml}$ ) inhibited the synthetic chemotactic peptide $N$-formyl-methionyl-leucyl-phenylalanine (fMLP)-induced release of elastase, a marker of inflammatory diseases and a serine proteinase released by activated human neutrophils in a concentration-dependent manner (Braga et al., 2006). Thymol (100 $\mu \mathrm{M})$ has been reported to alter prostaglandin catalyzed biosynthesis by inhibiting both isoforms of cyclooxygenase (COX), with the most active being against COX-1 with an $\mathrm{IC}_{50}$ value of $0.2 \mu \mathrm{M}$. These studies suggest the potential of thymol as an anti-inflammatory drug and indicate that it could be used in a similar fashion to non-steroidal antiinflammatory drugs (Marsik et al., 2005). Thymol $(1.1 \mu \mathrm{g} / \mathrm{ml})$ exhibited inhibitory effects against arachidonic-acid-induced blood coagulation and platelet aggregation in vitro (Enomoto et al., 2001). Thymol (50-150 $\mu \mathrm{M})$ attenuated bleomycin induced genotoxicity in human ovarian cells (SKOV-3) by virtue of its antioxidant and anti-inflammatory properties (Arab et al., 2015). Ku and Lin (2013) reported the anti-inflammatory nature of thymol by its inhibiting of the $\mathrm{T}$ cell immune response and improved T-helper cells-1 (Th1) (interleukin-2 (IL-2) and IFN- $\gamma /$ T-helper cells-2 (Th2) (interleukin-4 (IL-4), interleukin5 (IL-5) and interleukin-10 (IL-10) ratio in mouse primary splenocytes. Thymol $(40 \mu \mathrm{g} / \mathrm{ml})$ inhibited the LPS stimulated inflammatory response in mouse mammary epithelial cells mediating the down regulation of mitogen-activated protein kinases (MAPK) and nuclear factor-kB (NF- $\kappa \mathrm{B})$ signaling pathways (Liang et al., 2014).

Thymol $(7.5 \mathrm{mg} / \mathrm{kg})$ abrogated the induction of inflammation in isoproterenol (ISO) challenged rats, an animal model of myocardial infraction (MI), which had developed myocardial necrosis. (Nagoor Meeran et al., 2015b). Thymol isolated from essential oils of Lippia gracilis leaves has been shown to inhibit carrageenan-induced edema formation in the paws (administered at the dose of $200 \mathrm{mg} / \mathrm{kg}$ ) similar to the activity of positive control acetylsalicylic acid (300 mg/kg) (Mendes et al., 2010). Furthermore, treatment with this essential oil at the dose of 50,100 , and $200 \mathrm{mg} / \mathrm{kg}$ abrogated leukocyte migration into the peritoneal cavity in carrageenan-challenged experimental animals. Treatment with the essential oil also inhibited the occurrence of abdominal writhes in experimental animals induced by acetic acid.

Thymol isolated from leaf essential oils of Lippia gracilis $(32.68 \%)$ is believed to be primarily responsible for its antinociceptive and anti-inflammatory actions (Mendes et al., 2010). It has been shown to inhibit the release of arachidonic acid, COX and the biosynthesis of prostaglandins such as 
prostaglandin E2 (PGE2) in the visceral pain model (Mendes et al., 2010). Monteiro et al. (2007) has demonstrated the antiinflammatory effect of thymol present in the Lippia sidoides essential oil administered at the doses of 1 and $10 \mathrm{mg} / \mathrm{ear}$ in the acute ear edema model induced by 12-O-tetradecanoyl phorbol 13-acetate (TPA) in mice as evidenced by reduced edema (a 45.93 and $35.26 \%$ reduction, respectively). Thymol $(100 \mathrm{mg} / \mathrm{kg})$ attenuated inflammation and promoted wound healing in several rodent models via inhibiting the influx of leucocytes to the injured areas and thus preventing edema (Riella et al., 2012). Thymol exhibited potent anti-inflammatory activity by diminishing the release of inflammatory mediators viz. prostanoids, interleukins and leukotrienes in the buccal sites of young adults (Skold et al., 1998; Yucel-Lindberg et al., 1999). Thymol (10-250 $\mu \mathrm{g} /$ pellet) also elicited potent anti-inflammatory and antiangiogenic action in chorioallantoic membrane (CAM) assay using the experiment model of CAM of the fertilized hen's egg (Demirci et al., 2004).

Thymol $(50 \mu \mathrm{g} / \mathrm{ml})$ increased the mean fluorescence intensity (MFI) of cluster of differentiation 40 (CD40), cluster of differentiation 86 (CD86) and major histocompatibility complex-II (MHCII) expressions determined by flow cytometric analysis in the dendritic cells isolated from spleen of BALB/c mice (Amirghofran et al., 2016). Thymol inhibited ROS $\left(\mathrm{IC}_{50}=3 \mu \mathrm{g} / \mathrm{ml}\right)$, reactive nitrogen species (RNS) $\left(\mathrm{IC}_{50}=4.7\right)$ and significantly reduced generation of $\mathrm{NO}$ and $\mathrm{H}_{2} \mathrm{O}_{2}$ as well as activities of nitric oxide synthase (NOS) and nicotinamide adenine dinucleotide reduced oxidase (NADH oxidase) in LPSinduced murine macrophages (Kavoosi et al., 2012). A report from Hejazian (2006) has revealed that thymol present as an important constituent in the essential oil of Carum copticum $(20 \mathrm{mg} / \mathrm{kg})$ significantly diminished pain sensation in the inflammatory phase of the formalin test in mice. Lorente et al. (1989) revealed an important pharmacological advantage of the potentiation of anti-inflammatory activity of $\alpha$ and $\beta$-pinene mixtures $(80 \mathrm{mg} / \mathrm{kg})$ upon use in conjunction with thymol $(1 \mathrm{mg} / \mathrm{kg})$ in female Wistar rats. Thymol $(10$ and $20 \mu \mathrm{g} / \mathrm{ml})$ reduced inflammatory responses through modulation of the expression of c-Jun N-terminal kinase (JNK), stress-activated protein kinases (STAT-3), activator protein-1 (AP-1) and nuclear factors of activated T-cells (NFATs) in LPS treated macrophages (Gholijani et al., 2016). Thymol $(600 \mu \mathrm{M})$ reduced immunoglobulin-E ( $\mathrm{IgE}$ )-dependent responses in mast cells through the activation of apoptotic cell death in bone marrowderived mast cells (BMMCs) and BALB/c mice (Wechsler et al., 2014).

\section{Immunological Properties}

Thymol $(25-200 \mathrm{mg} / \mathrm{kg})$ was shown to modulate the immune system in cyclosporine-A treated Swiss albino mice by enhancing the expressions of cluster of differentiation 4 (CD4), cluster of differentiation 8 (CD8) and Th1 cytokines via upregulation of IFN- $\gamma$ expression and enhanced secretion of interleukin-12 (IL-12) (Chauhan et al., 2010). Khajeali et al. (2012) reported that thymol produced a significant increase in antibody titers against the Newcastle disease virus in broiler chickens. Thymol feed supplementation $(0-200 \mathrm{mg} / \mathrm{kg})$ improved the activities of digestive enzymes, growth indices and antioxidant status with declined MDA levels. It also improved the immune response via increasing tolerance to hypersensitivity and immunoglobulin G (IgG) in broiler chickens (Hashemipour et al., 2013). It improved innate immunity (Giannenas et al., 2012). Thymol diet supplementation (1\%) enhanced the levels of immunoglobulin A (IgA) and immunoglobulin $\mathrm{M}(\operatorname{IgM})$ in the sera of weaning pigs challenged with Salmonella typhimurium (Trevisi et al., 2010). Thymol treatment in low-weight growing-finishing pigs raised the percentage of $\mathrm{CD} 4+, \mathrm{CD} 8+$, and MHC-II in their peripheral blood and it also down regulated tumor necrosis factor- $\alpha$ (TNFa) expression in the stomach of post-weaned pigs (Taranu et al., 2012).

Thymol $\left(\mathrm{IC}_{50}=7.69 \mu \mathrm{g} / \mathrm{ml}\right)$ suppressed the adhesion and superoxide production on isolated ovine neutrophils and also anti-inflammatory property on sheep neutrophils (Farinacci et al., 2008). Thymol has been shown to improve the immune system by increasing the levels of IgA and IgM in the pig's gut (Li et al., 2012). Thymol $(10 \mu \mathrm{g} / \mathrm{ml})$ attenuated the maturation of dendritic cells and inhibited the mitogenic and allogenic $\mathrm{T}$ cell responses along with the secretion of IFN- $\gamma$ and IL4 cytokines (Amirghofran et al., 2016). Thymol $(10 \mu \mathrm{g} / \mathrm{ml})$ increased phagocytosis by enhancing the membrane fluidity of macrophages and suppressed the inflammatory responses by downregulating the secretion of pro-inflammatory cytokines by its potent immunostimulating effect (Chauhan et al., 2014).

\section{Antimicrobial Properties}

There are a convincing number of studies that reveal that thymol alone or thymol in plants along with other metabolites possess potent antimicrobial, antifungal, antibacterial, and antiparasitic properties. Marchese et al. (2016) has comprehensively reviewed the antimicrobial properties of thymol. Thymol (32.55\%) present in the essential oil of Thymus vulgaris L. showed bacteriostatic activity against most of the gram positive and negative bacteria (Marino et al., 1999). A report from Olasupo et al. (2003) revealed the antibacterial effect of thymol with the lowest minimum inhibitory concentration (MIC) values of $1.0 \mathrm{mmol} / \mathrm{L}$ (S. typhimurium) and $1.2 \mathrm{mmol} / \mathrm{L}$ (Escherichia coli). Thymol possesses antimicrobial activity against $S$. aureus (MIC: $0.31 \mathrm{mg} / \mathrm{ml}$ ) and E. coli (MIC: $5.00 \mathrm{mg} / \mathrm{ml}$ ) by the perturbation of the lipid fraction of the bacterial plasma membrane resulting in the leakage of intracellular materials (Trombetta et al., 2005). The thymol chemotypte of the essential oils of T. zygis and T. vulgaris has shown antibacterial effect against various gram negative and positive bacterial strains with MIC $\leq 0.2 \mu \mathrm{l} / \mathrm{ml}$ (Rota et al., 2008). Thymol $(200 \mathrm{mg} / \mathrm{ml}$ ) could inhibit the growth of $E$. coli. by inducing the permeabilization and depolarization of the cytoplasmic membrane (Xu et al., 2008). Thymol at $2.5 \mathrm{mM}$ inhibits the growth of $S$. aureus, E. coli and S. typhimurium. Furthermore, a synergistic interaction was found for thymol with all antibiotics tested against $E$. coli, S. typhimurium, S. aureus, and S. pyogenes (Palaniappan and Holley, 2010). Thymol ester derivatives were found to be more effective against streptococcus species (Mathela et al., 2010). Thymol was found to possess antibacterial activity against selected verocytotoxigenic E. coli (Rivas et al., 2010). Thymol 
(0.12\%) possess antifungal activity against $C$. albicans MTCC 227 biofilm inhibition (Pemmaraju et al., 2013). Gelatin films containing different thymol concentrations $(1-8 \%)$ produced inhibitory zones ranging from 30 to $46 \mathrm{~mm}$ against several bacteria. Thymol was more effective against Gram positive strains (Kavoosi et al., 2013). Thymol (15 and $30 \mathrm{mg} / \mathrm{kg}$ ) was shown to possess cytotoxic and antileishmanial activities in hamsters experimentally infected with Leishmania (Viannia) panamensis (Robledo et al., 2005). Thymol derivative named benzoyl-thymol was the best inhibitor $(8.67 \pm 0.28 \mu \mathrm{g} / \mathrm{mL})$ against Leishmania infantum chagasi (de Morais et al., 2014).

\section{Other Pharmacological Properties}

The blocking effect of thymol on voltage-activated sodium currents has been investigated in the in vitro setup using experimental cell models of animal and human origin. For skeletal muscle and the neuronal sodium channel, it showed a half-maximum blocking concentration $\left(\mathrm{IC}_{50}\right)$ of 104 and $149 \mu \mathrm{M}$, respectively. Blockade of voltage-operated sodium channels were attributed to confer the antinociceptive and anesthetic effects (Haeseler et al., 2002). In rat skeletal muscle fibers isolated enzymatically, thymol $(30-600 \mu \mathrm{g})$ treatment suppressed both calcium $\left(\mathrm{Ca}^{2+}\right)$ and potassium $\left(\mathrm{K}^{+}\right)$currents in a concentration-dependent manner with half-maximal effect $\left(\mathrm{EC}_{50}\right)$ values of $193 \pm 26$ and $93 \pm 11 \mu \mathrm{M}$ and Hill coefficients of $2.52 \pm 0.29$ and $1.51 \pm 0.18$ respectively (Szentandrassy et al., 2003). Thymol has been shown to accelerate $\mathrm{K}^{+}$-induced contracture in skeletal muscle and inhibit $\mathrm{Ca}^{2+}$-binding by the fragmented sarcoplasmic reticulum thus causing the suppression of relaxation (Ebashi, 1965). Thymol $(224 \mu \mathrm{M})$ was able to invoke the release of $\mathrm{Ca}^{2+}$ with an $\mathrm{EC}_{50}$ value of $158 \pm 16 \mu \mathrm{M}$ and activate ryanodine receptors in heavy sarcoplasmic reticulum vesicles isolated from skeletal muscle which were loaded with $\mathrm{Ca}^{2+}$ (Sarkozi et al., 2007). Thymol $(30 \mu \mathrm{M})$ was found to increase the depolarization-induced release of $\mathrm{Ca}^{2+}$ from the sarcoplasmic reticulum in rodents (Szentesi et al., 2004).

Thymol, at micro concentrations, reduced calcium dependent adenosine triphosphatase $\left(\mathrm{Ca}^{2+}\right.$-ATPase) activity and increased the permeability of $\mathrm{Ca}^{2+}$ in the sarcoplasmic membrane and it was found to increase the $\mathrm{Ca}^{2+}$ concentrations of neurons or of smooth muscle preparations (Hisayama and Takayanagi, 1986; Kostyuk et al., 1991). Thymol has agonistic effects for the adrenergic receptors $(\alpha 1, \alpha 2$, and $\beta)$ on the circular smoothmuscle strips (SMAs) isolated from stomach and vena portae of guinea pigs. Thymol $\left(10^{-4} \mathrm{M}\right)$ inhibits spontaneous contractile activity of the SMAs (100\%) and diminishes the excitatory effect of acetylcholine chloride to $35 \%$. Thymol via its influence on nerve cell $\alpha 2$-adrenergic receptors showed an analgesic effect (Beer et al., 2007). Thymol $(500 \mu \mathrm{M})$ was shown to activate the transient receptor potential channel (TRPV3) of the tongue and nasal epithelium (Boudry and Perrier, 2008). In transient receptor potential ankyrin1 (hTRPA1) expressing human embryonic kidney cells (HEK293 cells), thymol (6.25 and $25 \mu \mathrm{M})$ activated the response of the membrane potential and increased intracellular $\mathrm{Ca}^{2+}$ (Lee et al., 2008). Piglets fed diets supplemented with a combination of thymol (100 and $200 \mathrm{mg} / \mathrm{kg}$ ) and benzoic acid promoted nutrient digestion and absorption, reduced diarrhea and maintained a favorable micro-environment in the gut (Diao et al., 2015). Thymol $\left(10^{-3} \mathrm{M}\right)$ lysed dissociated mouse pancreatic acinar cells as evidenced by increased amylase secretion and the secretion of lactate dehydrogenase (LDH) by 315\% (Singh, 1980).

A report from Manabe et al. (1987) revealed the biphasic effects of thymol on hypnotic hemolysis. Thymol had a protective effect on erythrocytes at $0.06-1 \mathrm{mM}$ whereas at 2-4 mM it showed a lytic effect on erythrocytes. At a concentration of $1 \mathrm{mM}$, thymol showed maximum protection for erythrocytes. Thymol $(0.2-4 \mathrm{mM})$ increased the leakage of glutamic oxaloacetate transaminase (GOT) in hepatocytes isolated from male Sprague-Dawley rats. At $33^{\circ} \mathrm{C}$, thymol $(1 \mathrm{mM})$ depressed the phase transition temperature and thereby possessed a significant effect on membrane fluidity and it reduced the surface tension from 72 to 53 dye/cm (Manabe et al., 1987). Thymol $(0.75-2 \mathrm{mM})$ triggered the production of superoxide radicals in blood leukocytes in a concentration dependent manner (Suzuki et al., 1987). In guinea pig neutrophils, thymol $(1 \mathrm{mM})$ stimulated superoxide radical production and this was dependent on the initial density of the binding sites and the initial intracellular adenosine triphosphate (ATP) concentrations (Suzuki and Furuta, 1988). Thymol $(300 \mu \mathrm{g} / \mathrm{ml})$ stimulated cytotoxicity whereas treatment with thymol $(30-300 \mu \mathrm{g} / \mathrm{ml})$ dose dependently inhibited the synthesis of deoxyribonucleic acid (DNA), ribonucleic acid (RNA) and protein in cultured mammalian cells (Arai, 1988). Thymol (5\%) treatment increased the passive transport of leutinizing hormone-releasing hormone (LHRH) in the porcine epidermis (Bhatia and Singh, 1998). The partition coefficient of thymol was assessed to be $1.65 \pm 0.01 \times 10^{-2}$ and at the same concentration it enhanced the permeability of tamoxifen through the porcine epidermis (Gao and Singh, 1998). Thymol $(<0.05 \mathrm{mM})$ suppressed the action potential and reduced membrane resistance and potential in the stomach of guinea pigs at higher concentrations. Thymol (1 mM) inhibited the generation of spikes, hyperpolarized the membrane and resistance in the rectum and ileum (Ito and Kuriyama, 1974).

Thymol $(0.002$ and $0.00015 \mathrm{~mol} / \mathrm{L})$ has been shown to induce nerve blocking action in the phrenic nerve of rats (Seeman et al., 1974). In rabbit white muscle, thymol $(0.6 \mathrm{mM})$ induced accumulation of $\mathrm{Ca}^{+2}$ in the sarcoplasmic reticulum (Takishima et al., 1979). Thymol in $0.4 \%$ aqueous ethanol has been shown to reduce contractions $\left(\mathrm{ED}_{50}=0.86 \times 10^{-4} \mathrm{M}\right)$ in the guinea pig ileum induced by acetylcholine (Van den Broucke and Lemli, 1980). Thymol, a $\mathrm{Ca}^{2+}$ antagonist at the concentration of $1 \times 10^{-4} \mathrm{M}$, also reduced the contractions of rat vas deferens induced by 1-noradrenaline via blocking nerve fiber conductions and inhibited the contractions of guinea pig ileum induced by carbachol, histamine and dimethyl phenyl piperazinium (Van den Broucke and Lemli, 1982).

Viana et al. (1981) reported that thymol ( $2 \mathrm{mg} / \mathrm{kg})$ enhanced the contractions of isolated phrenic-diaphragm and muscles in rats. The same authors revealed that thymol $(100 \mu \mathrm{g})$ showed potent spasmolytic effects by decreasing the amplitude of peristaltic movements and muscle tone in rabbit duodenum. Thymol $(10-300 \mathrm{mg} / \mathrm{L})$ attenuated the force as well as rate of 
atrial contractions in guinea pigs and at a concentration of $10-300 \mu \mathrm{g} / \mathrm{ml}$ it decreased the aortic contractions isolated from New Zealand white rabbits. Thymol (0.001-0.01\%) possessed the ability to relax tension in rabbit intestinal muscles (RIFM 2001, unpublished). Thymol (20 or $40 \mathrm{mg} /$ day) dissolved in olive oil showed clear thyroid activation as detected by oxygen consumption and histological examinations in guinea pigs (Moller, 1939). Thymol (30-300 $\mu \mathrm{g} / \mathrm{L})$ showed a concentration dependent inhibition of DNA, RNA and proteins in V79 cells (Instituto Superiore di Sanita, 1999). Thymol (0.005 M) was shown to possess the ability to convert toxic metals into their non-toxic forms by forming metal complexes or by converting them into their reduced forms by virtue of its antioxidant property (Kishwar et al., 2013).

Thymol (200 mg/kg) attenuated Chang's disease in male $\mathrm{Balb} / \mathrm{c}$ mice by reducing parasitemia, trypomastigotes, heart amastigotes and inflammatory infiltrates by its antiTrypanosomaruzi effect (Juan et al., 2015). Supplementation of thymol rich sources like sage, rosemary extracts and pepper improved the digestibility of feed and the final performance in production (Hernandez et al., 2004). Thymol (2 and $3 \mathrm{~g} / \mathrm{kg}$ ) administration improved various growth parameters such as food conversion ratio, final weight, body growth and composition of tissues (whole body lipids, fibers and proteins) (Ahmadifar et al., 2011). Zheng et al. (2009) reported that thymol has a positive effect on the growth performance of channel catfish (Ictalurus panctatus). The presence of thymol might be responsible for the antispasmodic effect of the thyme extract (Engelbertz et al., 2012). Thymol (0-250 $\mu \mathrm{M})$ showed a weak genotoxic effect in L5178Y/Tk ${ }^{ \pm}$cells as analyzed by the micronucleus (MN) test and mouse lymphoma (MLA) assays (Maisanaba et al., 2015). Thymol $(100 \mu \mathrm{M})$ blocked voltage-gated sodium channels in stably transfected HEK 293 cells expressing $\alpha$-subunit of rat brain IIA or hSkM1 sodium channels and this is attributed to its antinoceptive and anesthetic properties (Haeseler et al., 2002).

\section{THYMOL IN CANCER CELLS}

Thymol showed anticancer properties in different types of cell lines mimicking human cancer and it demonstrated its potential as a chemopreventive or anticancer agent in various types of cancers. The protective effect of thymol against various types of cancers is represented in Table $\mathbf{1}$ and the schema of the protective effects of thymol shown in the studies is represented in Figure 1. The major mechanisms of anticancer actions of thymol include induction of apoptosis, anti-proliferation, inhibition of angiogenesis and migration as well as the diminution of umourigenesis by modulating the activity of carcinogen metabolizing enzymes.

\section{Glioblastoma Cells}

In human glioblastoma cells, thymol (200-600 $\mu \mathrm{M})$ produced a rise in $\left(\mathrm{Ca}^{2+}\right)_{\mathrm{i}}$ levels by prompting release of phospholipase $\mathrm{C}$ and protein kinase $\mathrm{C}$-dependent $\mathrm{Ca}^{2+}$ from the endoplasmic reticulum (ER) and entry of $\mathrm{Ca}^{2+}$ via non-store-operated $\mathrm{Ca}^{2+}$ channels. Furthermore, the cell death induced by thymol was found to involve apoptosis and necrosis as observed in Annexin V/PI staining (Hsu et al., 2011). Further, thymol $(6.0 \pm 0.11 \mathrm{mg} / \mathrm{g})$ present in the Zataria multiflora extract possessed radio sensitizing effect in human glioblastoma cells (Aghamohammadi et al., 2015).

\section{Glioma Cells}

Thymol $(30 \mu \mathrm{M})$ treatment in C6 glioma cells was found to reduce fetal bovine serum induced migration. It also diminished matrix metallopeptidase-9 (MMP9) and matrix metallopeptidase-2 (MMP2) production as well as protein kinase $\mathrm{C} \alpha(\mathrm{PKC} \alpha)$ and extracellular signal-regulated kinases (ERK1/2) phosphorylation (Lee et al., 2016).

\section{Breast Cancer Cells}

In breast cancer cells (MCF-7 cells), thymol (0.05-1.25 $\mu \mathrm{M})$ stimulated cytotoxicity by arresting the cell cycle in the G0/G1 phase (Jaafari et al., 2012). Thymol triggered cytotoxicity in MCF-7 breast cancer cell lines with an $\mathrm{LC}_{50}$ of $2.5 \mu \mathrm{g} / \mathrm{mL}$ (Melo et al., 2014). In another study, Thymol present in the essential oil of T. lanceolatus $\left(\mathrm{IC}_{50}=304.81 \mu \mathrm{g} / \mathrm{ml}\right)$ was shown to induce cytotoxicity and proliferation in MCF-7 cells (Khadir et al., 2016).

\section{Leukemia Cells}

Thymol (0.05-1.25 $\mu \mathrm{M})$ suppressed oxidant $\left(\mathrm{H}_{2} \mathrm{O}_{2}\right)$-induced DNA damage in K-562 cells (Horvathova et al., 2007). The ability of thymol to stop the cell cycle in G0/G1 phase of the K-562 cells seems to be due to its anti-tumor activity (Jaafari et al., 2012). Thymol $(5-100 \mu \mathrm{M})$ triggers cell death and cell cycle arrest at the sub G0/G1 phase by genomic DNA fragmentation pattern on acute promyelotic leukemia cells (HL-60 cells). Thymol increased the production of ROS and mitochondrial $\mathrm{H}_{2} \mathrm{O}_{2}$ thereby depolarizing mitochondrial membrane potential.

Thymol treatment induced caspase dependent apoptosis by up-regulating $\mathrm{Bcl}-2$ associated $\mathrm{X}$ protein (Bax) expression and down-regulating $\mathrm{B}$-cell lymphoma (Bcl-2) expression in a dosedependent manner. It further augmented the activation of caspase-3, 8, and 9 concomitant to Poly ADP ribose polymerase (PARP) cleavage that is the hallmark of caspase-dependent apoptosis. Furthermore, it also promoted the translocation of apoptosis inducing factor (AIF) from the mitochondria to cytosol and to nucleus, which shows its ability to induce caspaseindependent apoptosis. Altogether, the observations indicate that thymol-induced cell death includes both caspase-dependent and caspase-independent pathways (Dutta et al., 2011).

Thymol $(0.05-1.25 \mu \mathrm{M})$ also induced cytotoxicity mediating cell cycle arrest in the G0/G1 phase of $\mathrm{T}$ lymphoblastoid cell line (CEM) (Jaafari et al., 2012). A report from Pathania et al. (2013) has revealed that thymol (30, 50, and $70 \mu \mathrm{g} / \mathrm{ml})$ suppresses the phosphatidylinositide 3-kinases/Protein kinase $\mathrm{B} /$ mechanistic target of rapamycin (PI3K/Akt/mTOR) pathway and induced apoptotic cell death mediating both extrinsic and intrinsic pathways in HL-60 cells. A report from Miguel et al. (2015) has revealed that thymol $(0-500 \mu \mathrm{g} / \mathrm{ml})$ triggered an anti- proliferative effect in human acute monocytic leukemia cells (THP-1 cells). 
TABLE 1 | Effects of thymol in different experimental models of cancer.

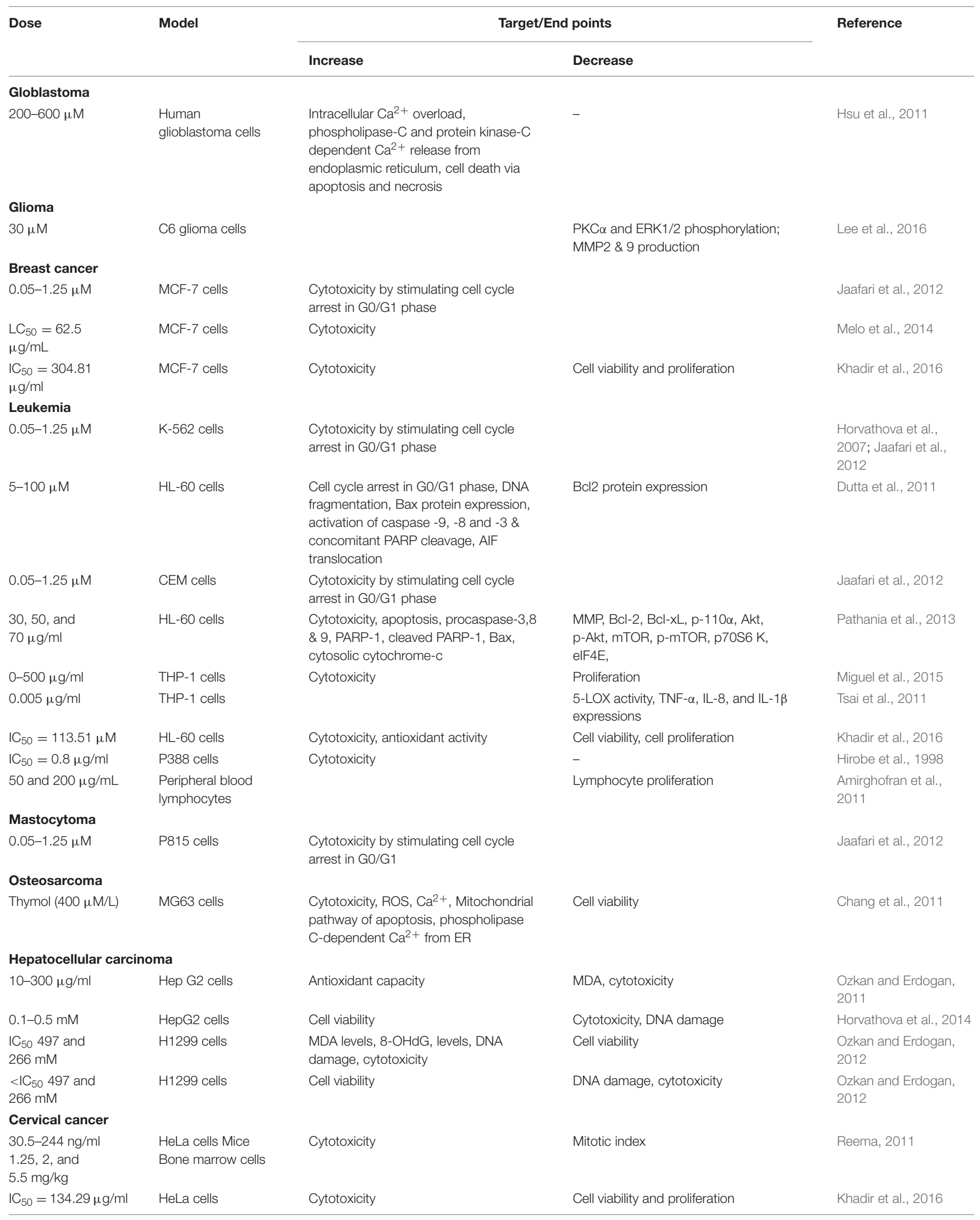


TABLE 1 | Continued

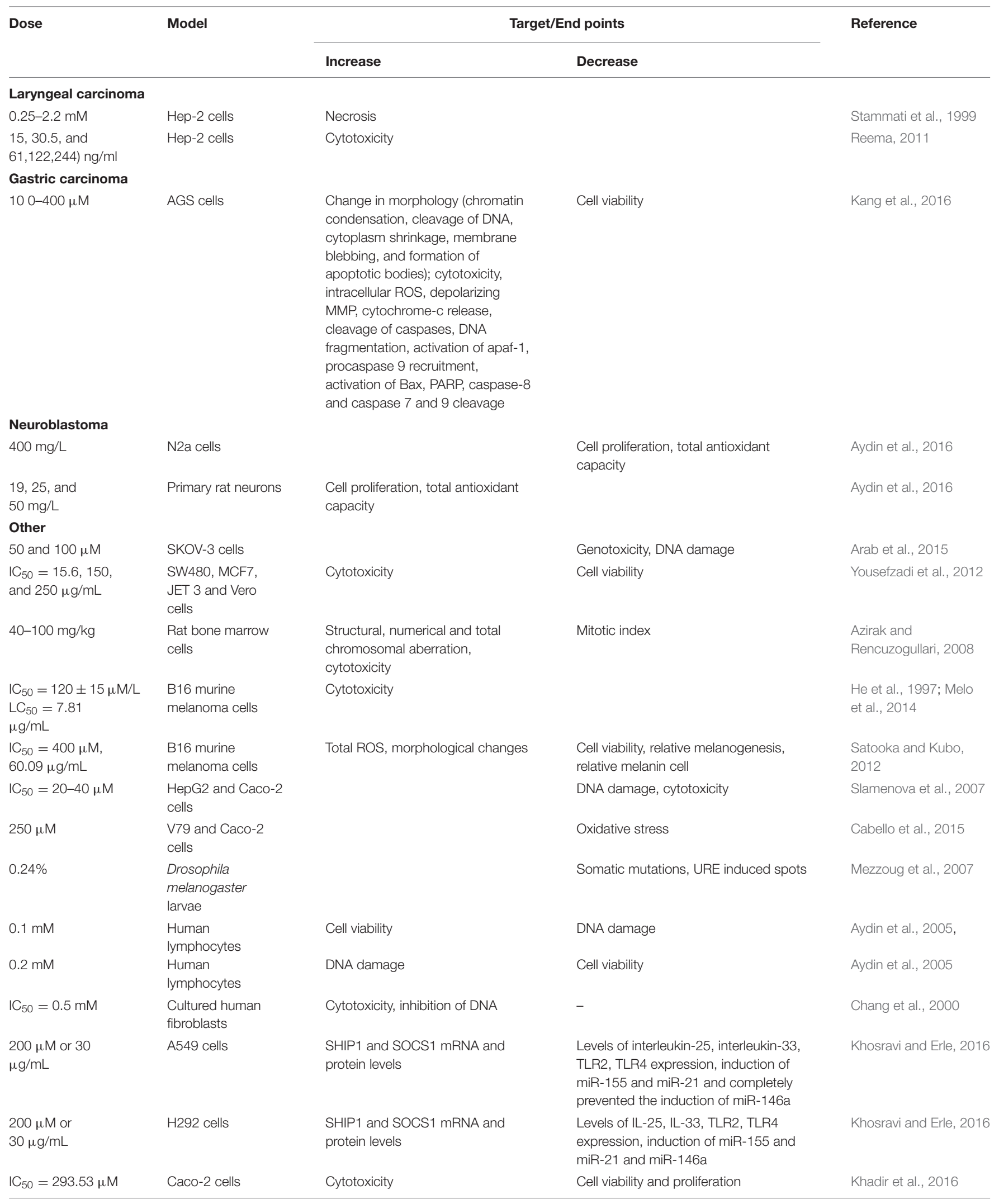




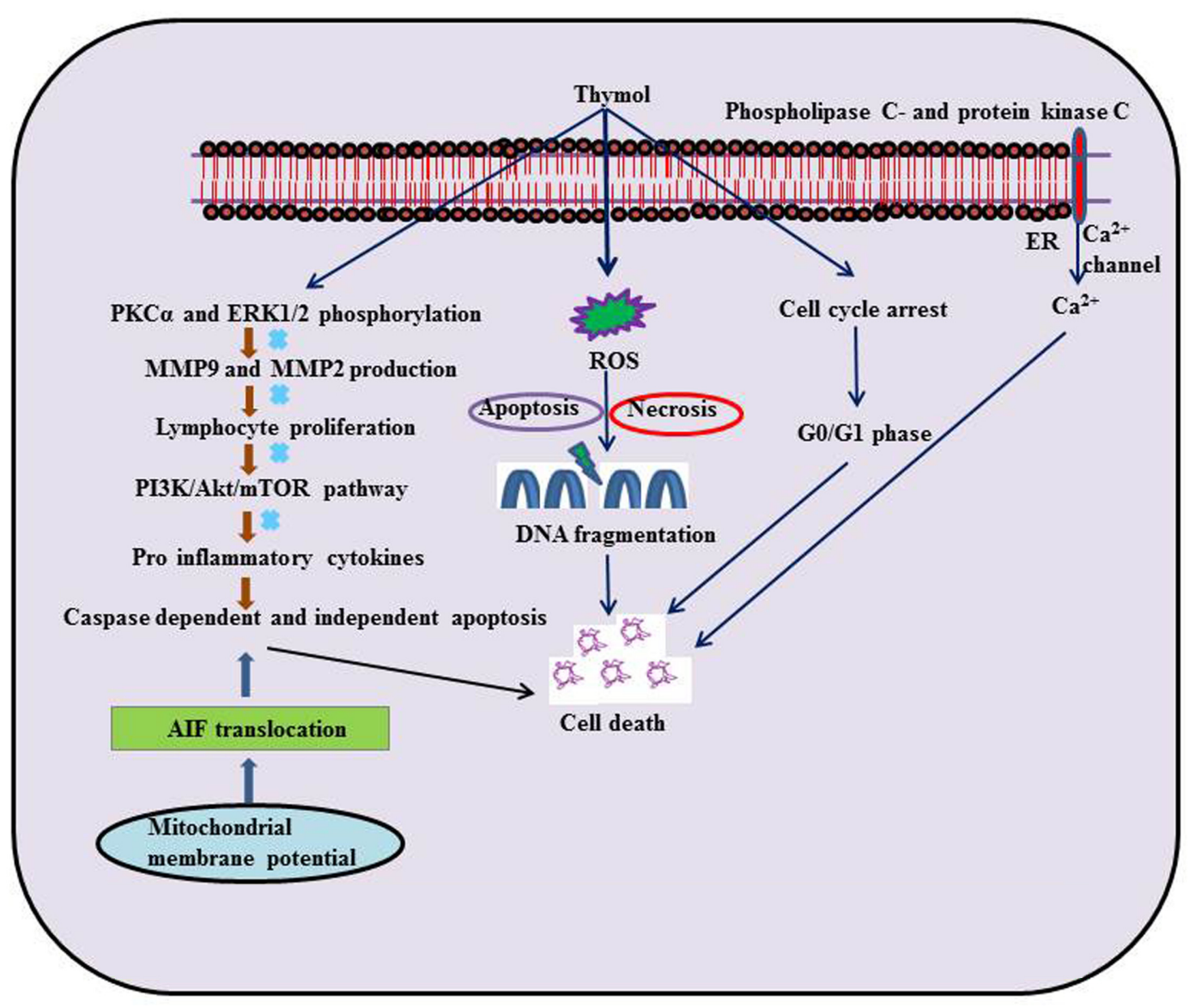

FIGURE 1 | Schematic representation on the effects of thymol in different experimental models of cancer.

A report from Khadir et al. (2016) has revealed that thymol present in Thymus lanceolatus $\left(\mathrm{IC}_{50}=113.51 \mu \mathrm{M}\right)$ essential oil triggered cytotoxicity in human leukemia HL-60 cells. Thymol $(0.005 \mu \mathrm{g} / \mathrm{ml})$ present in Thymus vulgaricus abrogated the activity of 5-lipoxygenase (5-LOX) and reduced the expression of cytokines viz. TNF- $\alpha$, interleukin-1 $\beta$ (IL$1 \beta$ ) and interleukin-8 (IL-8) in THP-1 cells (Tsai et al., 2011). Thymol (400 mg/kg) showed cytotoxicity toward P388 leukemia cells $\left(\mathrm{IC}_{50}=0.8 \mu \mathrm{g} / \mathrm{ml}\right)$ (Hirobe et al., 1998).

Thymol (50 and $200 \mu \mathrm{g} / \mathrm{mL}$ ) inhibited inducible lymphocyte proliferation (62.8 and $89.8 \%$ ) in a concentration dependent manner as the extracts of Thymus vulgaris, Thymus daenensis and Zataria multiflora (Labiatae) were evaluated for their pharmacological effect on mitogen phytohemagglutinin (PHA)-stimulated peripheral blood lymphocytes using a cell proliferation assay (Amirghofran et al., 2011).

\section{Mastocytoma Cells}

In P815 mastocytoma cell lines, thymol (0.05-1.25 $\mu \mathrm{M})$ showed the enhancement of cytotoxicity by arresting the cell cycle in G0/G1 phase (Jaafari et al., 2012).

\section{Osteosarcoma Cells}

In human osteosarcoma cells (MG63 cells), thymol (400 $\mu \mathrm{M} / \mathrm{L})$ treatment induced a rise in the levels of $\left(\mathrm{Ca}^{2+}\right)_{i}$ by triggering phospholipase C-dependent $\mathrm{Ca}^{2+}$ release from the $\mathrm{ER}$ and promoting protein kinase- $\mathrm{C}$ sensitive store-operated $\mathrm{Ca}^{2+}$ channels mediated entry of $\mathrm{Ca}^{2+}$. Thymol also triggered ROS mediated apoptotic cell death via mitochondrial pathways in MG63 cells (Chang et al., 2011).

\section{Hepatocellular Carcinoma Cells}

Thymol was shown to inhibit the proliferation of hepatocellular carcinoma (HCC) in the Bel-7402 cell line as analyzed by human 3-(4,5-dimethylthiazol-2-yl)-2,5-diphenyltetrazolium bromide (MTT) assay and acridine orange (AO)/ethidium bromide (EB) florescent staining (Yin et al., 2010). A report from Ozkan and Erdogan (2011) revealed that thymol (10-300 $\mu \mathrm{g} / \mathrm{ml})$ attenuates cytotoxicity in $\mathrm{H}_{2} \mathrm{O}_{2}$ induced cytotoxicity and membrane damage via inhibiting lipid peroxidation in hepatoma G2 cells (Hep G2 cells). Thymol (0.1-0.5 mM) showed a protective effect for DNA against $\mathrm{H}_{2} \mathrm{O}_{2}$ induced DNA damage in human hepatoma HepG2 cell lines (Horvathova et al., 2014). 
Thymol $\left(\mathrm{IC}_{50}=497\right.$ and $\left.266 \mathrm{mM}\right)$ was shown to induce DNA damage by increasing the levels of lipid peroxidation products; MDA and 8-hydroxy deoxyguanozine (8-OHdG) in parental and drug resistant human non-small cell lung carcinoma cells ( $\mathrm{H} 1299$ cell lines). Thymol $\left(<\mathrm{IC}_{50}=497\right.$ and $266 \mathrm{mM}$ ) treatment elicit protection against $\mathrm{H}_{2} \mathrm{O}_{2}$ induced cytotoxicity and showed stabilizing effects on membrane and DNA damage in H1299 cells (Ozkan and Erdogan, 2012). Thymol $(25-100 \mu \mathrm{M})$ also inhibited acetaminopheninduced cytotoxicity in HepG2 cells as evidenced by improved antioxidant activity and reduction in levels of the proinflammatory cytokines such as IL- $1 \beta$ and TNF- $\alpha$ (Palabiyik et al., 2016).

\section{Cervical Cancer Cells}

Cervical cancer is a cancer arising from the cervix due to abnormal cell growth that possesses the ability to invade or spread to other parts of the body. Thymol $(30.5-244 \mathrm{ng} / \mathrm{ml})$ induced cytotoxicity by inhibiting the growth of HeLa cells in a concentration-dependent manner. The observed inhibition at the concentration $30.5 \mathrm{ng} / \mathrm{ml}$ was $74.06-87.25 \%$. This study has revealed that thymol possesses strong antitumor activities by inducing cytotoxicity and decreasing the mitotic index at higher concentrations in HeLa cell lines (Reema, 2011). Thymol present in the essential oil of $T$. lanceolatus $\left(\mathrm{IC}_{50}=134.29 \mu \mathrm{g} / \mathrm{ml}\right.$ ) was shown to induce cytotoxicity in HeLa cells (Khadir et al., 2016).

\section{Laryngeal Carcinoma Cells}

In Hep-2 cells derived from human larynx carcinoma, thymol $(0.25-2.20 \mathrm{mM})$ treatment showed concentration-dependent inhibition of neutral red uptake (NRU) and total phenol content (TPC) $\left(\mathrm{IC}_{50}\right.$; NRU-0.71 mM and TPC-0.78 mM). It also exhibited concentration-dependent moderate cytotoxicity by inducing necrotic cell death (Stammati et al., 1999). Thymol $(15,30.5$, 61,122 and $244 \mathrm{ng} / \mathrm{ml}$ ) induced moderate cytotoxicity (51.45\%) in Hep-2 cell lines (Reema, 2011).

\section{Gastric Carcinoma Cells}

In human gastric AGS cells, Thymol (100-400 $\mu \mathrm{M})$ showed a change in cell morphology due to chromatin condensation, cleavage of DNA, cytoplasm shrinkage, and membrane blebbing. The beneficial effects in these cells were attributed to the generation of intracellular ROS, depolarization of mitochondrial membrane potential, apoptosis and impeding cell growth via intrinsic mitochondrial pathway and the activation of proapoptotic mitochondrial proteins; caspases, Bax and PARP (Kang et al., 2016).

\section{Neuroblastoma Cells}

Thymol $(400 \mathrm{mg} / \mathrm{L})$ decreased cell proliferation in cultured neuroblastoma cells (N2a cells) whereas thymol $(19,25$, and $50 \mathrm{mg} / \mathrm{L}$ ) increased the total antioxidant capacity in rat neurons but not in N2a cells. This report clearly revealed that thymol is a potent anticancer and antiproliferative agent (Aydin et al., 2016).

\section{Other Studies}

Thymol (50 and $100 \mu \mathrm{M}$ ) has been reported to inhibit bleomycin induced genotoxicity in human lymphocytes by its chemoprotective effect. It was also shown that thymol pretreatment in bleomycin treated human ovarian carcinoma cells (SKOV-3 cells) neither enhanced cell neither death nor cell protective effects but it prevented bleomycin induced DNA damage in normal cells. This study recommended the combination of thymol with various chemotherapeutic agents to minimize its toxicity on normal cells and to improve the effectiveness of cancer treatment (Arab et al., 2015).

A report from Yousefzadi et al. (2012) has revealed that thymol $(40.2 \%)$ present in the essential oil of S. sahendica $\left(\mathrm{IC}_{50}=15.6\right.$, $15.6,125$, and $250 \mu \mathrm{g} / \mathrm{ml}$ ) significantly reduced cell viability of human colon adenocarcinoma cells (SW480 cells), MCF7, JET3 and monkey kidney cells (Vero cells). Thymol (40-100 mg/kg) induced structural, numerical and total chromosomal aberrations (CA) in rat bone marrow cells and it also has cytotoxic effect in rat bone marrow cells by decreasing the mitotic index (Azirak and Rencuzogullari, 2008). Thymol (0.4 mM) exerted no appreciable effect against mutagenic and carcinogenic heterocyclic amines (HCAs) (Oguri et al., 1998). Thymol $\left(\mathrm{IC}_{50}=120 \pm 15 \mu \mathrm{M} / \mathrm{L}\right)$ displayed cytotoxicity on murine B16 melanomas in vitro and in vivo by its potent anti-tumor effect (He et al., 1997). Thymol $\left(\mathrm{LD}_{50}=7.81 \mu \mathrm{g} / \mathrm{mL}\right)$ present in the L. gracilis essential oil was shown to induce cytotoxicity in B16 murine melanoma cell line (Melo et al., 2014).

Thymol triggered cytotoxicity with an $\mathrm{IC}_{50}$ value of $400 \mu \mathrm{M}$ $(60.09 \mu \mathrm{g} / \mathrm{mL})$ along with oxidative stress in B16 melanoma cells. Thymol generates a phenoxy radical intermediate by its potent antioxidant effect followed by the production of ROS and quinine oxide derivatives. The toxicity of thymol at higher doses is due to the formation of antioxidant-related free radicals (Satooka and Kubo, 2012). Thymol $\left(\mathrm{IC}_{50}=20-\right.$ $40 \mu \mathrm{M})$ showed protective effect against $\mathrm{H}_{2} \mathrm{O}_{2}$ induced DNA double strand breaks in HepG2, human colonic cells (Caco2 cells) and hamster lung cells (V79 cells) (Slamenova et al., 2007). Thymol (0.24\%) present in the essential oil of Origanum compactum showed a strong inhibitory effect on indirectacting mutagen in urethane (URE) induced mutagenicity in Drosophila melanogaster as investigated by the somatic mutation and recombination test (SMART test). Thymol suppressed the mutations by $43 \%$ (Mezzoug et al., 2007). Thymol (0.1 mM) significantly decreased DNA double strand breaks in 2-amino-3methylimidazo(4,5-f)-quinoline (IQ) and mitomycin C (MMC) induced DNA damage in human lymphocytes and at higher concentrations of about $0.2 \mathrm{mM}$, thymol itself induced DNA damage in lymphocytes (Aydin et al., 2005). In the SOSchromotest and the DNA-repair test the genotoxic potential of thymol was found to be very weak (Stammati et al., 1999).

Thymol $\left(\mathrm{IC}_{50}=0.5 \mathrm{mM}\right)$ induced cytotoxicity by inhibiting DNA in a concentration dependent manner. However, thymol did not cause DNA single strand breaks in cultured human pulp fibroblasts (Chang et al., 2000). Combined treatment with carvacrol/thymol ( $200 \mu \mathrm{M}$, equal to $30 \mu \mathrm{g} / \mathrm{mL})$ suppressed chitin induced alterations in human lung carcinoma cells (A549 cells) 
and human lung mucoepidermoid carcinoma cells (H292 cells) (Khosravi and Erle, 2016). Thymol $\left(\mathrm{IC}_{50}=293.53 \mu \mathrm{M}\right)$ present in the T. lanceolatus extract was shown to induce cytotoxicity in Caco-2 cells (Khadir et al., 2016).

\section{THYMOL IN CARDIOMETABOLIC DISEASES}

The protective effects of thymol in various cardiovascular related disorders such as MI, hyperlipidemia and several others are represented in Tables 2, 3 and the schema of the protective effects of thymol shown in the studies is represented in Figures 2, 3.

\section{Myocardial Infarction}

Thymol $(7.5 \mathrm{mg} / \mathrm{kg})$ was shown to inhibit the occurrence of oxidative stress in rats challenged with ISO, an agent which commonly induces myocardial necrosis. The benficial effects were attributed to decreased levels of lipid peroxidation products such as thiobarbituric acid reactive substances (TBARS), lipid hydroperoxides $(\mathrm{LOOH}$ ) and conjugated dienes (CDs) in plasma. Further, it also normalized non-enzymatic antioxidants such as vitamin-C, vitamin-E and GSH in the plasma due to its potent antioxidant action (Nagoor Meeran and Prince, 2012). Furthermore, thymol attenuates altered lipid metabolism [decreased the levels/concentrations of serum and heart lipids such as total cholesterol, triglycerides (TGs) and free fatty acids (FFAs)], reinstating the normal levels of lipoproteins (increased HDL-C with decreased LDL-C and VLDL-C levels in the circulation) in ISO-induced myocardial infarcted rats. Thymol was shown to attenuate the alterations in the activities of lipid marker enzymes such as 3-hydroxy-3-methyl-glutaryl-coenzyme A reductase (HMG-CoA reductase) and lecithin-cholesterol acyltransferase (LCAT) in the liver, inhibiting tachycardia (increased heart rate), decreasing atherogenic index, and the levels of serum cardiac troponins, altered electrocardiographic patterns (ST segment elevation), cardiac hypertrophy (decreased heart weight and left ventricular weight/body weight) and apoptosis (increased expression of myocardial Bcl-2 gene and decreased expression of Bax-gene in ISO-induced myocardial infracted rats) (Nagoor Meeran et al., 2015b). Also, thymol has been shown to attenuate inflammation of the myocardium by inhibiting the release of lysosomal enzymes ( $\beta$-glucuronidase, $\beta$-galactosidase, cathepsin- $B$ and cathepsin-D) from the heart to the circulation by decreasing the levels of lysosomal TBARS, release of inflammatory marker such as high sensitive C-reactive protein (hsCRP) and down regulating the myocardial expressions of pro-inflammatory cytokines such as TNF- $\alpha$, interleukin-6 (IL-6) and IL-1 $\beta$ genes in ISO-induced myocardial infracted rats. The transmission electron microscopic findings revealed preservation of lysosomal architecture and histopathological salvage in concurrence with the biochemical observations (Nagoor Meeran et al., 2015b).

Oral administration of thymol abrogates myocardial membrane destabilization by inhibiting myocardial oxidative stress (decreased concentrations of lipid peroxidations products in heart and improved activities of antioxidant enzymes), reduced leakage of the cardiac marker enzyme LDH into the circulation, decreasing the activity of $\mathrm{Ca}^{2+}$ ATPase and increasing the activity of sodium/potassium dependent adenosine triphosphatase $\left(\mathrm{Na}^{+} / \mathrm{K}^{+}\right.$ATPase) in ISO-induced infarcted rats. Furthermore, thymol also increased $\mathrm{K}^{+}$concentrations and enhanced sodium $\left(\mathrm{Na}^{+}\right)$and $\mathrm{Ca}^{2+}$ concentrations in the heart. Also, thymol significantly diminished the myocardial infarct size as analyzed by 2,3,5-triphenyl tetrazolium chloride (TTC) assay due its potent membrane stabilizing property (Nagoor Meeran et al., 2015c). Thymol was shown to inhibit mitochondrial dysfunction in ISO-induced myocardial necrosis in rats. Pre and co-treatment with thymol showed decreased heart mitochondrial lipid peroxidation products (TBARS and LOOH), lipids (cholesterol, TGs, FFAs and phospholipids (PLs), $\mathrm{Ca}^{2+}$ and significant increase in the activities of heart mitochondrial antioxidants (SOD, catalase, GPx, GSH) and mitochondrial marker enzymes such as isocitrate dehydrogenase (ICDH), malate dehydrogenase $(\mathrm{MDH}), \alpha$-ketoglutarate dehydrogenase $(\alpha-\mathrm{KGDH})$, reduced nicotinamide adenine dinucleotide dehydrogenase (NADH dehydrogenase) and cytochrome-Coxidase) in ISO-induced MI in rats. It also enhanced the ATP levels and diminshed the mitochondrial swelling. Transmission electron microscopic study on heart mitochondria confirmed the biochemical findings of the study. This study revealed the ability of thymol in protecting the heart mitochondria against ISO induced oxidative stress in rats (Nagoor Meeran et al., 2016b).

Thymol has been shown to decrease the levels of plasma uric acid and glycoprotein components viz. hexose, hexosamine, fucose and sialic acid in ISO-induced rats due to its potent antioxidant property (Nagoor Meeran et al., 2014). Thymol was shown to inhibit apoptosis by decreasing oxidative stress in ISO-induced myocardial infracted rats. Thymol treatment decreased the concentrations of lipid peroxidation products and increased the status of antioxidants in the myocardium such as GPx, GSH, vitamin-C and vitamin-E. It also decreased the myocardial gene expressions of caspase-8, 9 and Fas genes and increased the expressions of B-cell lymphoma extra-large (BcL$\mathrm{xL})$ gene. Histopathological and the in vitro ferric reducing antioxidant power (FRAP) assay confirmed the biochemical observations. This study revealed the protective effect of thymol against apoptotic cell death in the heart by attenuating oxidative stress (Nagoor Meeran et al., 2016a). In all these studies, thymol pre- and co-treatment in rats appear devoid of any deleterious effects which is suggestive of its safety. These preclinical studies recommended the clinical trials to reveal the exact dosage of thymol against $\mathrm{MI}$ in humans.

\section{Doxorubicin Induced Cardiotoxicity}

Thymol has been shown to abrogate oxidative stress, inflammation and apoptosis in doxorubicin induced cardiotoxicity in rats. Thymol $(20 \mathrm{mg} / \mathrm{kg})$, in pre- and cotreated rats, was shown to decrease the levels of serum $\mathrm{LDH}$, aspartate transaminase (AST), creatine kinase (CPK), creatine kinase-MB (CK-MB), cardiac troponin-I and TNF- $\alpha$ with decreased concentrations of caspase- 3 and MDA in the heart. The activities of antioxidants such SOD, catalase and GSH were 
TABLE 2 | Effect of thymol in different animal models of cardiovascular diseases.

\begin{tabular}{|c|c|c|c|c|}
\hline Dose & Model & \multicolumn{2}{|c|}{ Target/End points } & Reference \\
\hline $\begin{array}{l}7.5 \mathrm{mg} / \mathrm{kg} \text { and } \\
50 \mu \mathrm{M}\end{array}$ & $\begin{array}{l}\text { ISO (100 mg/kg)-induced } \\
\text { myocardial necrosis in Male } \\
\text { albino Wistar rats }\end{array}$ & $\begin{array}{l}\text { Vitamin-C, vitamin-E, GSH, } \\
\text { reducing power }\end{array}$ & $\begin{array}{l}\text { Serum CK-MB, plasma TBARS, } \mathrm{LOOH} \\
\text { and CDs }\end{array}$ & $\begin{array}{l}\text { Nagoor Meeran and } \\
\text { Prince, } 2012\end{array}$ \\
\hline $7.5 \mathrm{mg} / \mathrm{kg}$ & $\begin{array}{l}\text { ISO (100 mg/kg)-induced } \\
\text { myocardial necrosis in Male } \\
\text { albino Wistar rats }\end{array}$ & - & $\begin{array}{l}\text { hsCRP, Iysosomal TBARS, serum and } \\
\text { heart } \beta \text {-glucuronidase, } \beta \text {-galactosidase, } \\
\text { cathepsin-B and cathepsin-D, } \\
\text { myocardial TNF- } \alpha \text {, IL- } 6 \text { and IL- } 1 \beta \text {, } \\
\text { lysosomal destabilization }\end{array}$ & $\begin{array}{l}\text { Nagoor Meeran et al., } \\
2015 b\end{array}$ \\
\hline $\begin{array}{l}7.5 \mathrm{mg} / \mathrm{kg} \text { and } \\
50 \mu \mathrm{M}\end{array}$ & $\begin{array}{l}\text { ISO (100 mg/kg)-induced } \\
\text { myocardial necrosis in Male } \\
\text { albino Wistar rats }\end{array}$ & $\begin{array}{l}\text { Mitochondrial complex enzymes } \\
\text { and cytochrome-C-oxidase, ATP, } \\
\text { scavenging of hydroxyl radicals }\end{array}$ & $\begin{array}{l}\text { Serum CK, LDH, mitochondrial TBARS, } \\
\text { LOOH, cholesterol, TGs, FFAs, } \\
\text { phospholipids, } \mathrm{Ca}^{2+} \text { overload }\end{array}$ & $\begin{array}{l}\text { Nagoor Meeran et al., } \\
2016 \mathrm{~b}\end{array}$ \\
\hline $\begin{array}{l}7.5 \mathrm{mg} / \mathrm{kg} \text { and } \\
50 \mu \mathrm{M}\end{array}$ & $\begin{array}{l}\text { ISO (100 mg/kg)-induced } \\
\text { myocardial necrosis in rats }\end{array}$ & $\begin{array}{l}\text { Myocardial } \mathrm{CK}, \mathrm{H}_{2} \mathrm{O}_{2} \text { radical } \\
\text { scavenging }\end{array}$ & $\begin{array}{l}\text { Plasma uric acid, protein, hexose, } \\
\text { hexosamine, fucose and sialic acid }\end{array}$ & $\begin{array}{l}\text { Nagoor Meeran et al., } \\
2014\end{array}$ \\
\hline 7.5 mg/kg & $\begin{array}{l}\text { ISO (100 mg/kg)-induced } \\
\text { myocardial necrosis in rats }\end{array}$ & $\begin{array}{l}\text { Heart } L O O H, G P x, G S H \text {, } \\
\text { vitamin-C, vitamin-E and } \\
\text { expression of } B c L-x L\end{array}$ & $\begin{array}{l}\text { Serum CK, gene expressions of } \\
\text { caspase- } 8 \text {, caspase- } 9 \text { and Fas }\end{array}$ & $\begin{array}{l}\text { Nagoor Meeran et al., } \\
2016 b\end{array}$ \\
\hline \multicolumn{5}{|c|}{ Drug induced cardiotoxicity } \\
\hline 20 mg/kg & $\begin{array}{l}\text { Doxorubicin } \\
(10 \mathrm{mg} / \mathrm{kg}) \text {-induced male } \\
\text { Swiss Albino rats }\end{array}$ & SOD, catalase, GSH in the heart & $\begin{array}{l}\text { Serum LDH, CK, CK-MB, AST, TNF- } \alpha \text {, } \\
\text { MDA, cardiac troponins }\end{array}$ & El-Sayed et al., 2016 \\
\hline 5-25 $\mu \mathrm{g} / \mathrm{mL}$ & $\begin{array}{l}\text { oxLDL-stimulated } \\
\text { THP-1-macrophages }\end{array}$ & IL-10 expression & $\begin{array}{l}\text { TNF- } \alpha, \mathrm{IL}-1 \beta \text {, and IL- } 6 \text { expressions, } \\
\text { translocation of NF- } \mathrm{kB} \text { into the } \\
\text { nucleous }\end{array}$ & $\begin{array}{l}\text { Ocana-Fuentes et al., } \\
\text { 2010; Ocana and } \\
\text { Reglero, } 2012\end{array}$ \\
\hline $1.25-10 \mu \mathrm{M}$ & Human aortic endothelial cells & Antioxidant activity & CDs, LDL-oxidation & Pearson et al., 1997 \\
\hline \multicolumn{5}{|l|}{ Hypertension } \\
\hline $\begin{array}{l}300,400, \text { and } \\
1000 \mu \mathrm{M}\end{array}$ & Rat isolated aorta & $\mathrm{Ca}^{2+}$ release & $\begin{array}{l}\text { PHE induced Endothelial ring } \\
\text { contractions } \mathrm{CaCl}_{2} \text { induced } \\
\text { contractions in } \mathrm{Ca}^{2+} \text { free medium }\end{array}$ & $\begin{array}{l}\text { Peixoto-Neves et al., } \\
2010\end{array}$ \\
\hline $1-10 \mathrm{mg} / \mathrm{kg}$ & Male or female Wistar rats & - & $\begin{array}{l}\text { Systolic, diastolic, and mean arterial } \\
\text { pressure, heart rate }\end{array}$ & Aftab et al., 1995 \\
\hline $\begin{array}{l}10-300 \mu \mathrm{g} / \mathrm{ml} \\
\left(\mathrm{IC}_{50}=100 \mu \mathrm{g} / \mathrm{ml}\right)\end{array}$ & Guinea pig atria & Vasorelaxation & $\begin{array}{l}\text { Force and rateg of atrial contractions, } \\
\mathrm{K}^{+} \text {induced contractions }\end{array}$ & $\begin{array}{l}\text { RIFM 2001, } \\
\text { unpublished }\end{array}$ \\
\hline $10-300 \mu \mathrm{g} / \mathrm{ml}$ & Rabbit aorta & Vasorelaxation & & $\begin{array}{l}\text { RIFM 2001, } \\
\text { unpublished }\end{array}$ \\
\hline $\begin{array}{l}1,3 \text {, and } \\
10 \mathrm{mg} / \mathrm{kg}\end{array}$ & Wistar rats & - & Blood pressure and heart rate & $\begin{array}{l}\text { RIFM 2001, } \\
\text { unpublished }\end{array}$ \\
\hline $5 \mathrm{mg} / \mathrm{kg}$ & Rabbits & & Blood pressure & $\begin{array}{l}\text { RIFM 2001, } \\
\text { unpublished }\end{array}$ \\
\hline
\end{tabular}


TABLE 2 | Continued

\begin{tabular}{|c|c|c|c|c|}
\hline \multirow[t]{2}{*}{ Dose } & \multirow[t]{2}{*}{ Model } & \multicolumn{2}{|c|}{ Target/End points } & \multirow[t]{2}{*}{ Reference } \\
\hline & & Increase & Decrease & \\
\hline \multicolumn{5}{|l|}{ Arrythmias } \\
\hline $\begin{array}{l}10,100, \text { and } \\
250 \mu \mathrm{M}\end{array}$ & $\begin{array}{l}\text { Canine ventricular } \\
\text { cardiomyocytes }\end{array}$ & $I_{\mathrm{Ca}}$ inactivation & $\begin{array}{l}\mathrm{K}^{+} \text {and } \mathrm{Ca}^{2+} \text { currents, action potential, } \\
\mathrm{V}_{\max }\end{array}$ & Magyar et al., 2002 \\
\hline
\end{tabular}

TABLE 3 | Effect of thymol in different experimental models of metabolic disorders and nephrotoxicity.

\begin{tabular}{|c|c|c|c|c|}
\hline \multirow[t]{2}{*}{ Dose } & \multirow[t]{2}{*}{ Model } & \multicolumn{2}{|c|}{ Target/End points } & \multirow[t]{2}{*}{ Reference } \\
\hline & & Increase & Decrease & \\
\hline \multicolumn{5}{|l|}{ Diabetes Mellitus } \\
\hline $40 \mathrm{mg} / \mathrm{kg}$ & $\begin{array}{l}\text { High fat diet induced } \\
\text { C57BL/6J mice }\end{array}$ & $\begin{array}{l}\text { Adiponectin, LCAT, LPL, HDL-C, } \\
\text { CPT, ME, PAP }\end{array}$ & $\begin{array}{l}\text { Body weight, HOMA-IR, HbA1c, insulin, } \\
\text { glucose, leptin, HMG-CoA reductase, } \\
\text { plasma and hepatic lipid profile, fatty acid } \\
\beta \text {-oxidation, activities of G6PD and FAS }\end{array}$ & $\begin{array}{l}\text { Saravanan and } \\
\text { Pari, } 2015\end{array}$ \\
\hline $40 \mathrm{mg} / \mathrm{kg}$ & $\begin{array}{l}\text { High fat diet induced } \\
\text { C57BL/6J mice }\end{array}$ & $\begin{array}{l}\text { Serum protein,, SOD, catalase, GPx, } \\
\text { GRx, GST, GSH, vitamin-C, vitamin-E } \\
\text { in erythrocyte and kidney }\end{array}$ & $\begin{array}{l}\text { Blood glucose, insulin, BUN, creatinine, } \\
\text { TBARS, LOOH, erythrocytes and kidney, } \\
\text { total cholesterol, TGs, FFAs, PLs in kidney,, } \\
\text { gene expressions of SREBP-1c, TGF- } \beta 1 \text {, } \\
\text { VEGF, lipid accumulation }\end{array}$ & $\begin{array}{l}\text { Saravanan and } \\
\text { Pari, } 2016\end{array}$ \\
\hline $0.5-2.0 \mathrm{mg} / \mathrm{ml}$ & $\begin{array}{l}\text { AAPH induced diabetic } \\
\text { erythrocytes }\end{array}$ & Free radical scavenging & Lipid peroxidation, RBC hemolysis & Aman et al., 2013 \\
\hline \multicolumn{5}{|l|}{ Obesity } \\
\hline 30 mg/kg & HFD-induced murine model & $\begin{array}{l}\text { HDL-C levels, SOD and catalase in } \\
\text { serum }\end{array}$ & $\begin{array}{l}\text { Body weight, food intake, serum and } \\
\text { hepatic function parameters and lipid profile }\end{array}$ & Haque et al., 2014 \\
\hline $20 \mu \mathrm{M}$ & 3T3-L1 white adipocytes & $\begin{array}{l}\text { Expressions of signaling molecules of } \\
\text { glucose homeostasis and lipid } \\
\text { metabolism }\end{array}$ & $\begin{array}{l}\text { Cytotoxicity, LPL expression, TG } \\
\text { accumulation }\end{array}$ & Choi et al., 2016 \\
\hline \multicolumn{5}{|l|}{ Nephrotoxicity } \\
\hline $20 \mathrm{mg} / \mathrm{kg}$ & $\begin{array}{l}\text { Cisplatin induced male } \\
\text { adult Swiss albino rats }\end{array}$ & Antioxidants in kidney & $\begin{array}{l}\text { Decrease creatinine and BUN, TNF- } \alpha \text {, } \\
\text { caspase- } 3 \text { and MDA }\end{array}$ & $\begin{array}{l}\text { El-Sayed et al., } \\
2014\end{array}$ \\
\hline $200-500 \mu \mathrm{M}$ & MDCK cells & $\mathrm{Ca}^{2+}$, apoptosis, ROS & Cell viability & Chang et al., 2014 \\
\hline 50 and 150 mg/kg & $\begin{array}{l}\text { Cisplatin induced Swiss } \\
\text { albino mice }\end{array}$ & $\begin{array}{l}\text { Uptake of 99mTc-DMSA (dimer } \\
\text { captosuccinic acid) }\end{array}$ & $\begin{array}{l}\text { Tubular necrosis, degeneration, epithelial } \\
\text { vacuolization, swelling }\end{array}$ & $\begin{array}{l}\text { Hosseinimehr et al., } \\
2015\end{array}$ \\
\hline
\end{tabular}

shown to increase in thymol pre- and co-treated doxorubicininduced cardiotoxic rats. This study has shown that the combined treatment of thymol and carvacrol revealed a much better effect than the treatment with thymol and carvacrol alone in doxorubicin-induced cardiotoxic rats. But, thymol possesses a more superior effect than its isomer carvacrol in the same model and the actions are attributed to the antioxidant, antiinflammatory, and antiapoptotic activity of thymol (El-Sayed et al., 2016). A report from Cardoso et al. (2016) has revealed that thymol $(10-100 \mathrm{mg} / \mathrm{kg})$ attenuates inflammation and recovers skeletal muscle from cardiotoxicity in mice.

\section{Atheroscelerosis}

A report from Yu et al. (2016) showed that thymol attenuates oxidative stress, aortic intimal thickening, and inflammation by regulating gene expression in hyperlipidemic rabbits. Thymol (3 and $6 \mathrm{mg} / \mathrm{kg}$ ) supplementation has been shown to decrease the levels of TGs, total cholesterol, LDL-C, MDA, high sensitive C-reactive protein, intimal thickening of aorta with increased levels of HDL-C and total antioxidant capacity in hyperlipidemic rabbits induced by giving a high fat diet. Furthermore, thymol ( 3 and $6 \mathrm{mg} / \mathrm{kg}$ ) was shown to decrease the mRNA expressions of IL- $1 \beta$, IL- 6 , TNF- $\alpha$, TNF- $\beta$, Vascular cell adhesion protein 1 (VCAM-1), monocyte chemo attractant protein-1 (MCP-1) and MMP-9 in hyperlipidemic rabbits. Thymol $(121.4 \mu \mathrm{M})$ effectively scavenged DPPH and 2,2' -azinobis(3-ethylbenzothiazoline-6-sulphonic acid (ABTS) radicals which revealed its potent antioxidant and free radical scavenging properties. Finally, thymol administration lowered serum lipids and attenuated oxidative stress followed by an inflammatory response in hyperlipidemic rabbits. This study recommended further studies to reveal the mechanism of action of thymol on endothelial dysfunction and smooth muscle cell migration (Yu et al., 2016). Thymol $(5-25 \mu \mathrm{g} / \mathrm{mL})$ administration showed decreased expressions of pro-inflammatory cytokines (TNF- $\alpha$, IL-1 $\beta$ and IL-6) with increased expression of IL-10 that inhibited translocation of NF- $\mathrm{kB}$ into the nucleus in the oxidative-LDL induced THP-1 macrophages, a cellular model of inflammation/atherogenesis (Ocana-Fuentes et al., 2010; Ocana and Reglero, 2012). In human aortic endothelial 


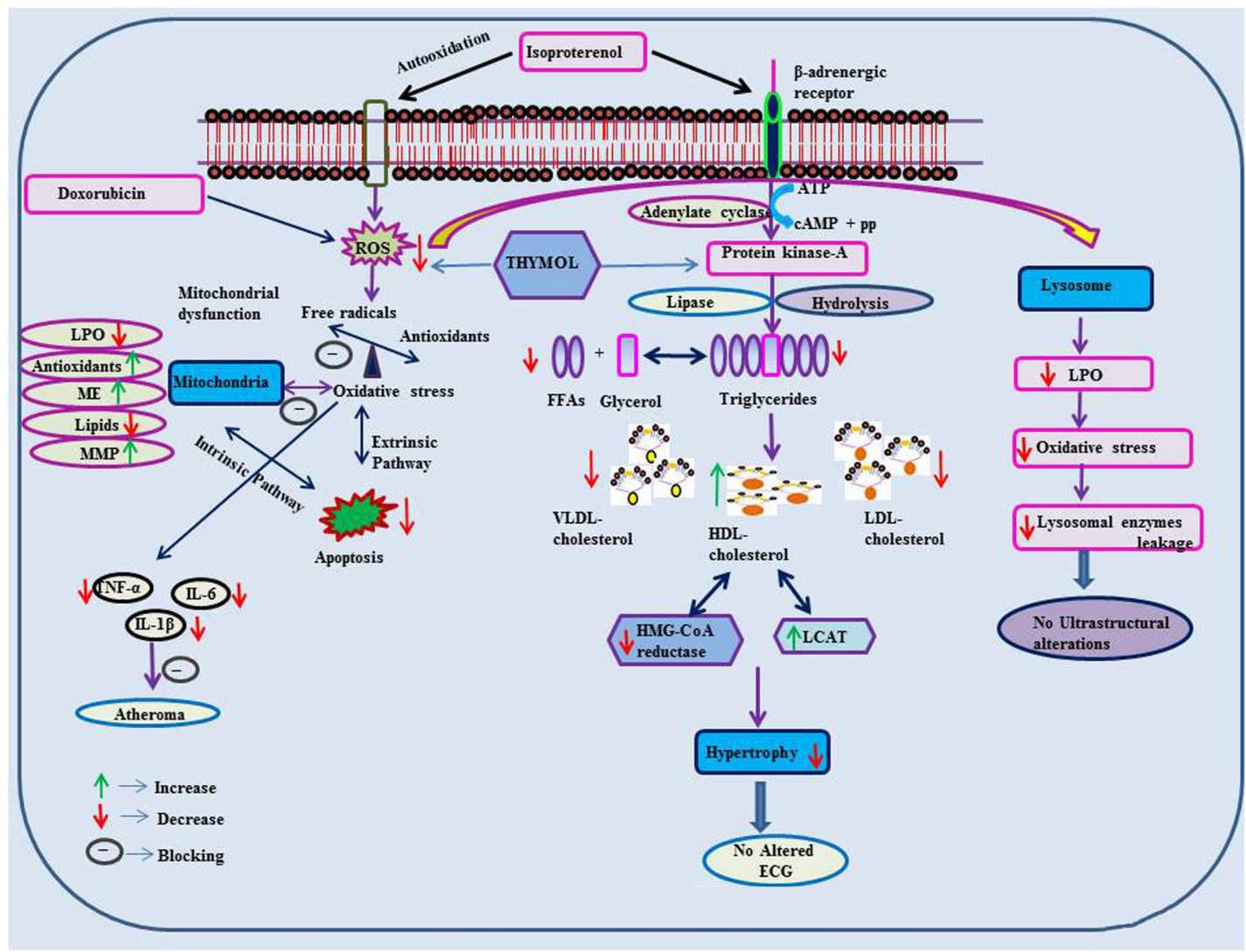

FIGURE 2 | Effect of thymol on ISO and doxorubicin induced cardiotoxicity.

cells, thymol (1.25-10 $\mu \mathrm{M})$ produced a concentration dependent inhibition of oxidation of LDL-C (Pearson et al., 1997).

\section{Hypertension}

Thymol has been shown to exhibit vasorelaxant activities in the isolated rat aorta. Thymol showed relaxation on aortic ring preparations in a concentration dependent manner using potassium chloride $(\mathrm{KCl})$ or using phenylephrine (PHE) $\left(\mathrm{IC}_{50}\right.$ value of $64.40 \pm 4.41$ and $78.80 \pm 11.91 \mu \mathrm{M})$ and $(\mathrm{PHE}, 0.1 \mu \mathrm{M})$ $\left(\mathrm{IC}_{50}\right.$ value of $106.40 \pm 11.37$ and $\left.145.40 \pm 6.07 \mu \mathrm{M}\right)$. In isolated rat aorta, endothelium-independent relaxation induced by thymol occurs via release of $\mathrm{Ca}^{2+}$ from the sarcoplasmic reticulum diminishing the sensitivity of contractile elements to $\mathrm{Ca}^{2+}$ and preventing the influx of $\mathrm{Ca}^{2+}$ across the membrane (Peixoto-Neves et al., 2010). Thymol (1-10 mg/kg) showed a dose dependent decline in blood pressure and heart rate in rats. Also, it decreased the force and rate of atrial contractions in spontaneously beating atria (Aftab et al., 1995). Thymol (10$300 \mu \mathrm{g} / \mathrm{ml})\left(\mathrm{IC}_{50}=100 \mu \mathrm{g} / \mathrm{ml}, 0.1 \mathrm{mM}\right)$ dose dependently triggered the relaxation of potassium and norepinephrine induced contractions in the rabbit aorta. Thymol by virtue of its $\mathrm{Ca}^{2+}$ channel blocking effect expressed its hypotensive and bradycardiac effects in various animal studies (Aftab et al., 1995). Thymol (1, 3, and $10 \mathrm{mg} / \mathrm{kg}$ ) administration decreased the blood pressure and heart rate of Wistar rats whereas thymol (5 mg/kg) attenuated blood pressure in rabbits (RIFM, 2001, unpublished).

\section{Cardiac Arrythmias}

Thymol (10 and $100 \mu \mathrm{M}$ ) induced cardiac arrhythmias via concentration-dependent inhibition of $\mathrm{K}^{+}$and $\mathrm{Ca}^{2+}$ currents in canine ventricular cardiomyocytes using microelectrode and patch clamp techniques. Thymol $(10 \mu \mathrm{M})$ ablated the action potential notch whereas thymol $(100 \mu \mathrm{M})$ decreased the duration of the action potential, reduced maximum velocity $\left(\mathrm{V}_{\max }\right)$ and the depression of the plateau. These results are found in line with the activity of thymol in ventricular myocytes isolated from healthy human hearts (Magyar et al., 2002). Thymol $(10-1000 \mu \mathrm{M})$ inhibits the effect of L-type $\mathrm{Ca}^{2+}$ currents in human and canine ventricular myocytes using the 'patch clamp technique' in the 'whole-cell' configuration on the inactivation of the channel machinery (Magyar et al., 2004). Thymol triggers negative inotropic actions in canine and guinea pig preparations in a concentration-dependent manner. At lower concentrations, thymol reduced intracellular $\mathrm{Ca}^{2+}$ transients without altering the contractile function whereas $\mathrm{Ca}^{2+}$ transients and at higher concentrations suppressed contractions in guinea pig hearts. Thymol reduced the activity of $\mathrm{Ca}^{2+}$ pump by inducing 


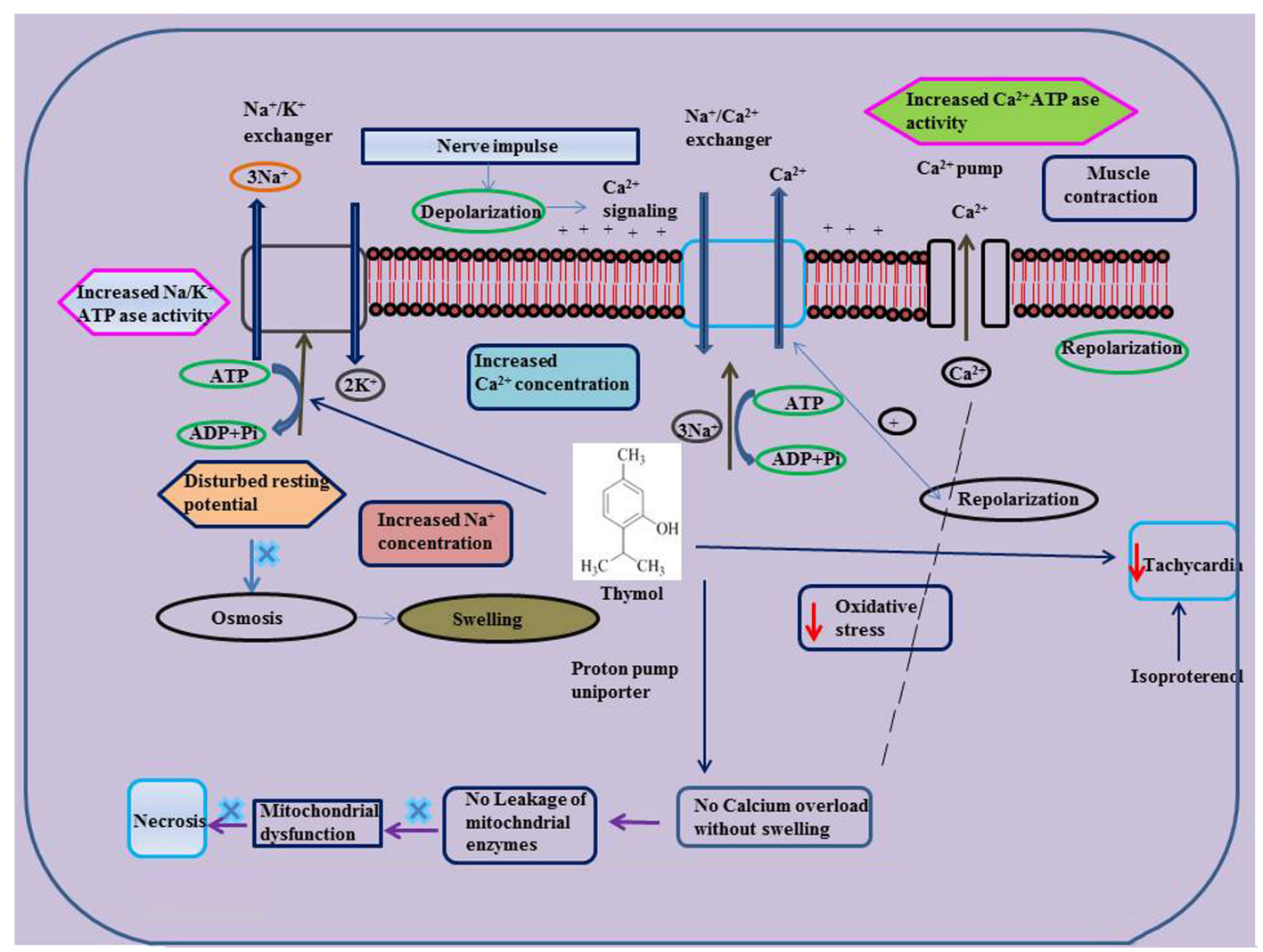

FIGURE 3 | Effect of thymol on ISO induced altered ionic homeostasis and mitochondrial dysfunction.

rapid release of $\mathrm{Ca}^{2+}$ in canine sarcoplasmic reticular vesicles (Szentandrassy et al., 2004).

\section{THYMOL IN METABOLIC DISORDERS}

The protective effects of thymol in metabolic disorders such as diabetes mellitus and obesity are represented in Table $\mathbf{3}$ and the schema of the protective effects of thymol shown in the studies are depicted in Figure 4.

\section{Diabetes Mellitus}

Thymol was shown to protect against various metabolic disorders. A report from Saravanan and Pari (2015) has revealed the anti-hyperglycemic and hyperlipidemic activity of thymol in high fat diet induced type-2 diabetes in C57BL/6J mice. Thymol $(40 \mathrm{mg} / \mathrm{kg})$ administration was shown to reduce final body weight, HOMA of insulin resistance (HOMA-IR), glycosylated hemoglobin (HbA1c), plasma insulin and blood glucose in high fat diet induced type-2 diabetes in C57BL/6J mice. Thymol suppressed plasma and hepatic levels of total cholesterol, TGs, FFAs, PLs, LDL-C and significantly increased the levels of HDL$\mathrm{C}$ in high fat diet induced mice. Furthermore, thymol treatment increased the levels of adiponectin and decreased the levels of leptin in high fat diet (HFD) mice. Also, thymol inhibited alterations in the activities of lipid metabolizing enzymes (significant increase in the activities of LCAT, lipoprotein lipase (LPL) and decrease in the activities of HMG-CoA reductase in HFD mice). Thymol treatment reduced the levels of fatty acid $\beta$-oxidation and the activities of glucose 6-phosphate dehydrogenase (G6PD), fatty acid synthase (FAS) along with increased activities of carnitine palmitoyl transferase (CPT), malic enzyme (ME) and phosphatidate phosphohydrolase (PAP) in HFD mice (Saravanan and Pari, 2015).

Another study reported by the same group, has revealed that thymol abrogated diabetic nephropathy in HFD-induced diabetes in C57BL/6J mice (Saravanan and Pari, 2016). Thymol $(40 \mathrm{mg} / \mathrm{kg})$ treatment for a period of 5 weeks reduced blood glucose level and improves the parameters of renal function. Thymol treatment also suppressed the activation of vascular endothelial growth factor (VEGF) and transforming growth factor- $\beta 1$ (TGF- $\beta 1)$ and down regulated expression of sterol regulatory element binding protein-1c (SREBP-1c) and reduced lipid accumulation in the kidneys. Extracellular mesangial matrix expansion and glomerulosclerosis were suppressed also by thymol in HFD induced mice as evidenced in histological studies and it also enhanced antioxidant status and inhibited lipid peroxidation in erythrocytes and kidneys. Thymol (0.5$2.0 \mathrm{mg} / \mathrm{ml}$ ) has been shown to protect red blood cells (RBCs) from 2,2-azo-bis(2-amidinopropane) dihydrochloride (AAPH) induced hemolysis in diabetic patients due to its potent antioxidant and free radical scavenging effect (Aman 


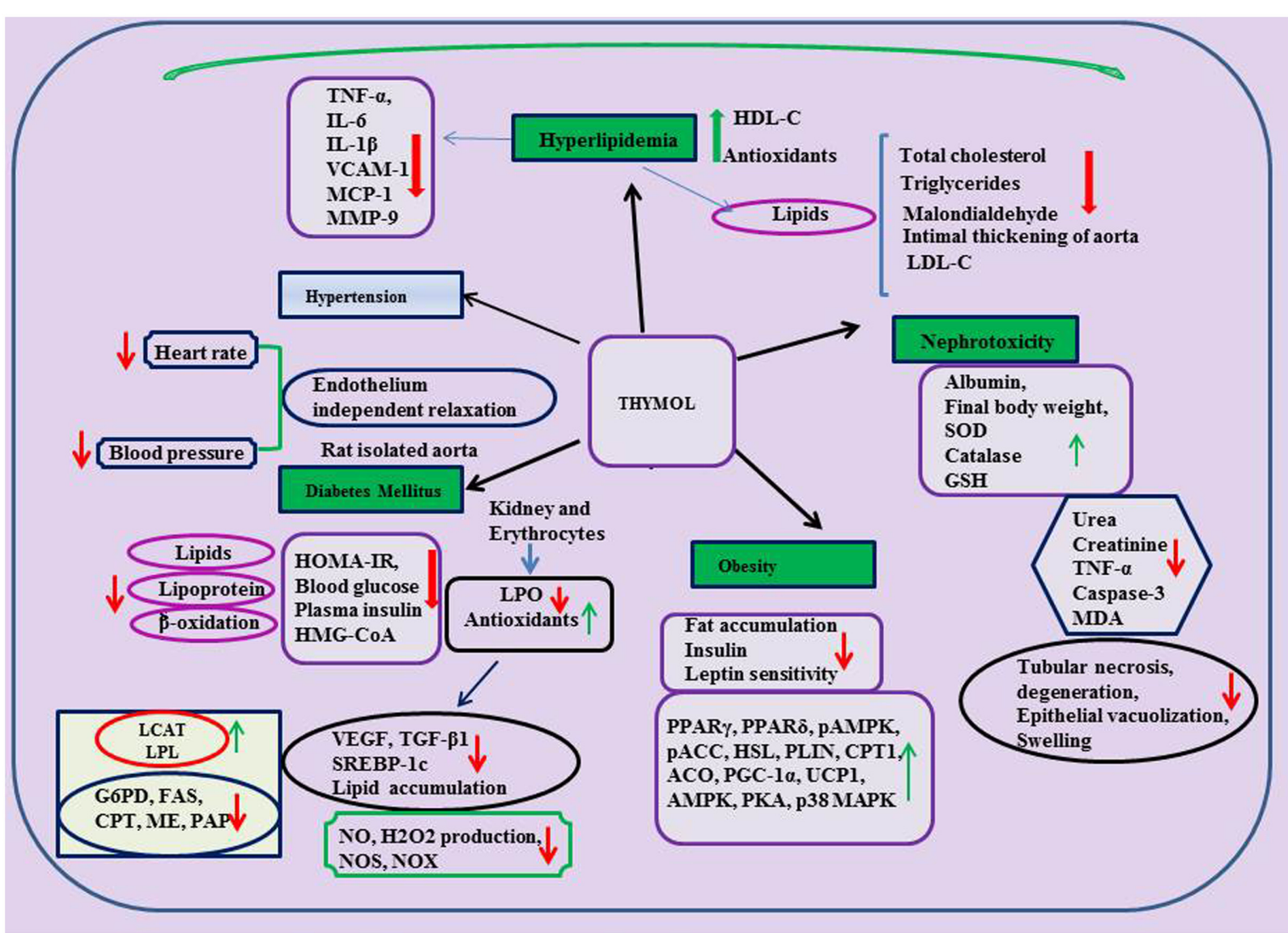

FIGURE 4 | Effect of thymol on metabolic and kidney disorders.

et al., 2013). According to the report of Kavoosi and Teixeira da Silva (2012), thymol reduced $\mathrm{NO}, \mathrm{H}_{2} \mathrm{O}_{2}$ production along with NOS, NADH-oxidase (NOX) activities in human monocytes cultured in the presence of $20 \mathrm{mM}$ glucose. Thymol present in the methanolic extract of Thymus quinquecostatus showed inhibitory effect on the enzymes $\alpha$-amylase and $\alpha$-glucosidase responsible for breakdown of carbohydrates and further intestinal absorption $\left(\mathrm{IC}_{50}=4.39 \pm 0.22 \mu \mathrm{g} / \mathrm{ml}\right)$ (Hyun et al., 2014). The findings demonstrate that thymol has promising potential in the treatment of hyperglycemia and associated complication.

\section{Obesity}

Obesity is defined as excessive adiposity and is one of the major health and socioeconomic burdens which leads to a number of chronic diseases such as coronary heart disease (Sedova et al., 2004), diabetes (Lazar, 2005; Sanchez-Castillo et al., 2005), hyperlipidemia (Jeusette et al., 2005) and various cancers (Stunkard and Allison, 2003a,b; Stunkard et al., 2003). Thymol (30 mg/kg) was shown to inhibit the accumulation of visceral fats, enhance insulin and leptin sensitivity and improve lipid lowering action as well as augment antioxidant status in HFD-induced obesity in murine models (Haque et al., 2014). Thymol $(20 \mu \mathrm{M})$ has been shown to promote the biogenesis of mitochondria and increase the expression of brown fat-specific markers along with improved expressions of peroxisome proliferator activated receptor- $\gamma(\operatorname{PPAR} \gamma)$, peroxisome proliferator activated receptor- $\delta$ (PPAR $\delta$ ), phospho AMP-activated protein kinase (pAMPK), pampk; Phospho acyl-CoA carboxylase (pACC), hormone-sensitive lipase (HSL), perilipin (PLIN), carnitine palmitoyltransferase-1 (CPT1), acyl-coenzyme A oxidase-1 (ACO), peroxisome proliferator-activated receptor gamma coactivator 1-alpha (PGC-1 $\alpha$ ), and uncoupling protein 1 (UCP1) in the browning of white adipocytes (3T3-L1 white adipocytes) which play an important role in glucose homeostasis and lipid metabolism. Altogether, the findings reveal that thymol has the potential to regulate oxidation of fatty acids, lipolysis augmentation, lipolysis reduction and thermogenesis. Thymol possesses the ability to activate the $\beta 3$-adrenergic receptor along with AMPK-activated protein kinase (AMPK), protein kinase-A (PKA), and p38 mitogen-activated protein kinase (p38 MAPK) pathways and it could be the reason for its ability to trigger UCP1 expression in other brown fat-specific markers (Choi et al., 2016).

\section{THYMOL IN RENAL DISEASES}

The protective effects of thymol in renal diseases are represented in Table 3 and the schema of the protective effects of thymol 
shown in the studies are represented in Figure 4. Thymol $(20 \mathrm{mg} / \mathrm{kg}$ ) was shown to inhibit cisplatin-induced renal injury by attenuating oxidative stress, inflammation and apoptosis in male adult Swiss Albino rats (El-Sayed et al., 2014). Thymol (200$500 \mu \mathrm{M})$ induced $\mathrm{Ca}^{2+}$ release from the ER which facilitated the entry of $\mathrm{Ca}^{2+}$ via store-operated $\mathrm{Ca}^{2+}$ entry in MadinDarby canine kidney (MDCK) renal tubular cells. Thymol triggers cell death by promoting apoptosis mediated by ROS in MDCK renal tubular cells (Chang et al., 2014). Thymol's (50 and $150 \mathrm{mg} / \mathrm{kg}$ ) beneficial effect on cisplatin-induced renal injury in mice was also demonstrated by quantitative renal dimer captosuccinic acid ( ${ }^{99 m}$ Tc-DMSA) uptake concomitant to potent antioxidant and anti-inflammatory properties. ${ }^{99 m} \mathrm{Tc}$-DMSA uptake per gram tissue of kidneys in \%ID/g was $65.02 \pm 32.21$ and $88.46 \pm 20.46$ in the thymol (50 and $150 \mathrm{mg} / \mathrm{kg}$ ) treated mice induced with cisplatin. Furthermore, Thymol administration increased the level of \%ID/g (Hosseinimehr et al., 2015).

\section{THYMOL IN GASTROINTESTINAL DISORDERS}

The protective effects of thymol in gastrointestinal disorders are represented in Table 4. Nowadays, the prevalence of inflammatory diseases in the intestines are rising as a serious problem in humans. The increased expressions of proinflammatory cytokines such as interleukin-1 (IL-1), IL-6, IL-8, TNF- $\alpha$, IL-12, and IFN $\gamma$ were reported in the inflamed intestinal mucosa of both animal and humans (Rogler and Andus, 1998; Wirtz and Neurath, 2000; Bertevello et al., 2005; Raddatz et al., 2005; Bukovska et al., 2007). Thymol present in thyme and oregano oils $(0.05-0.4 \%)$ was shown to inhibit 2,4,6trinitrobenzenesulfonic acid-induced colitis by decreasing the mRNA expressions of pro inflammatory cytokines (IL-1 $\beta$, IL-6, granulocyte-macrophage colony-stimulating factor (GM-CSF) and TNF- $\alpha$ ) and protein expressions of IL- $1 \beta$ and IL- 6 in mice (Bukovska et al., 2007). A report from Platel and Srinivasan (2004) demonstrated the ability of thymol to prompt secretion of salivary amylase in humans and of bile acids, gastric and pancreatic enzymes such as lipase, amylase and proteases and intestinal mucosa in rats. Thymol administration increased the activities of pancreatic amylase, maltase and trypsin in broiler chickens (Jang et al., 2007).

Thymol $(100 \mathrm{mg} / \mathrm{kg})$ has been shown to attenuate acute and chronic ulcers induced by various agents such as ethanol, indomethacin and acetic acid by attenuating the inflammatory process, i.e., infiltration of inflammatory cells and edema. This gastroprotective effect of thymol is believed to be due to increased mucus secretion, prostaglandins and ATP-sensitive $\mathrm{K}^{+}$ channels (Ribeiro et al., 2016). Thymol (10-100 $\mu \mathrm{M})$ induced the secretion of chloride $\left(\mathrm{Cl}^{-}\right)$and bicarbonate $\left(\mathrm{HCO}^{-}\right)$ions in piglets' intestinal epithelial cells via the nervous pathway likely through the activation of nervous nicotinic receptors (Boudry and Perrier, 2008). Thymol $(0-100 \mu \mathrm{M})$ showed concentration dependent antispasmodic effects by inhibiting $\mathrm{K}^{+}$induced tracheal contractions in rats $(43 \%$ at $100 \mu \mathrm{M}$ thymol). It also inhibits Barium chloride $\left(\mathrm{BaCl}_{2}\right)$ induced tracheal contractions in a concentration dependent manner where the $\mathrm{EC}_{50}$ of thymol is in the range of $70 \mu \mathrm{g} / \mathrm{mL}$. Also, Thymol $(1.3 \mathrm{mg} / \mathrm{kg})$ increased the mucociliary clearance in mouse trachea in situ (Begrow et al., 2010). Thymol (10 mg/kg) administered orally inhibited ethanol induced gastric mucosal injury by up-regulating the status of antioxidants and down regulating MMP-9 protein expressions (Chauhan and Kang, 2015). Thymol (0.072\%) in $434 \mu \mathrm{g} / \mathrm{ml}$ extract of Thymus vulgaris concentration dependently antagonized the contractions in guinea pig trachea brought by four different spasmogens (Meister et al., 1999).

Thymol $\left(\mathrm{IC}_{50}=2.85 \times 10^{-2} \pm 1.2 \times 10^{-2} \mu \mathrm{g} / \mathrm{mL}\right)$ isolated from $A$. phleoides essential oil has been shown to induce antispasmodic activity in charcoal meal mice (Astudillo et al., 2014). Thymol present in the extract of Trachyspermum ammi $(0.01 \%)$ showed anti-spasmolytic and anti-spasmodic action against contractions in the isolated rat's ileum induced by acetylcholine (Hejazian et al., 2014). Thymol (0-2 mM) exerted its relaxant effect on smooth muscle cells by opposing $\mathrm{Ca}^{2+}$ activation and ATP dependent process by its potent anti-spasmodic effect (Tamura and Iwamoto, 2004). Thymol (50 $\mathrm{mg} / \mathrm{kg}$ ) was shown to influence gastric maturation and function via stimulation of gastric proliferative activity and the control of digestive activity in weaned pigs (Colombo et al., 2014).

\section{THYMOL IN MODELS OF LIVER DISEASES}

The protective effects of thymol in liver diseases are represented in Table 4.

\section{Hepatotoxicity}

Thymol (30 mg/100 g) has been shown to inhibit oxidative stress in hydrocortisone-induced hepatotoxicity in rats by attenuating lipid peroxidation and enhancing antioxidant defense in the liver. Thymol treatment reinstated the activities of liver marker enzymes attributed to its potent free radical scavenging and antioxidant activity (Aboelwafa and Yousef, 2015). Thymol (300 mg/kg) has been shown to attenuate carbon tetrachloride induced liver injury in mice. Thymol treatment reduced lipid peroxidation and increased the status of antioxidants thereby preventing oxidative stress mediated hepatic injury in mice. Liver function tests and histological studies confirmed the other biochemical findings of the study (Al-Malki, 2010). In carbon tetrachloride $\left(\mathrm{CCl}_{4}\right)(20 \mu \mathrm{l} / \mathrm{kg})$ induced liver injury, thymol (300 $\mathrm{mg} / \mathrm{kg}$ ) abrogated lipid peroxidation and reinstated the normal activities of hepatic marker enzymes in the liver due to its potent free radical scavenging property (Alam et al., 1999).

Thymol (150 mg/kg) showed to inhibit paracetamol induced hepatotoxicity in mice by preventing the alterations in the activities of hepatic marker enzymes (Janbaz et al., 2003). Thymol $(50 \mu \mathrm{g} / \mathrm{ml})$ inhibited oxidative damage to liver cells by inhibiting ROS overproduction, ameliorating lipid peroxidation, preventing apoptosis and increasing antioxidant levels in tertbutyl hydroperoxide (t-BHP) induced Chang liver cells (Kim 
TABLE 4 | Effect of thymol in different experimental models of gastrointestinal diseases.

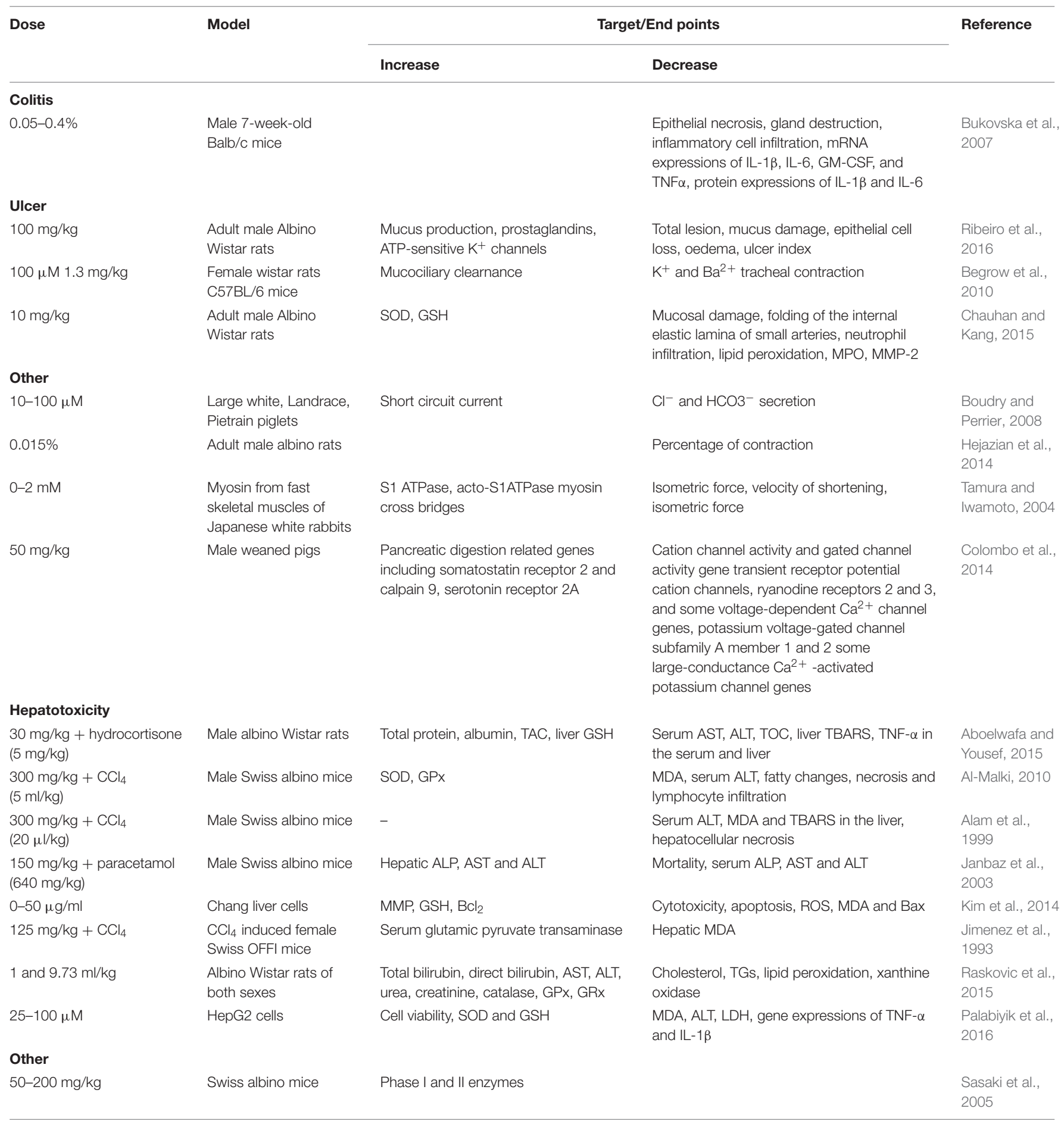

et al., 2014). Thymol $(125 \mathrm{mg} / \mathrm{kg})$ attenuated $\mathrm{CCl}_{4}$ induced hepatoxicity by inhibiting the release of glutamic pyruvate transaminase into the serum and it also decreased the levels of MDA in female Swiss OFFI mice (Jimenez et al., 1993). Thymol $(1 \mathrm{ml} / \mathrm{kg}$ and $5.6 \mathrm{ml} / \mathrm{kg})$ from thyme tincture and syrup inhibited $\mathrm{CCl}_{4}$ induced liver injury by reducing lipid peroxidation mediated oxidative stress and it maintained the levels of hepatic markers in Wistar rats (Raskovic et al., 2015). Thymol (50-200 mg/kg) increased the activities of phase I enzymes such as 7-ethoxycoumarin O-deethylase (ECOD) and phase II enzymes such as GST and quinone reductase (QR) along with raised activities of GST alpha and GST micro in mouse liver (Sasaki et al., 2005). In t-BHP induced Chang liver cells, thymol $(50 \mu \mathrm{g} / \mathrm{ml})$ inhibited lipid 
peroxidation and apoptosis by increasing the status of the antioxidants (Kim et al., 2014). These results revealed that thymol imparts a hepatoprotective effect on t-BHP-induced oxidative injury by mediating antioxidant activity (Kim et al., 2014). Thymol (25-100 $\mu \mathrm{M})$ increased both enzymatic and nonenzymatic antioxidants and inhibited lipid peroxidation against paracetamol-induced toxicity in human HepG2 cells (Palabiyik et al., 2016).

\section{THYMOL IN MODELS OF CNS DISEASES}

The protective effects of thymol in CNS diseases are represented in Table 5.

\section{Alzheimer's Disease (AD)}

Alzheimer's disease is the most common cause of age associated dementia that leads decline in cognitive function following memory deterioration. Nowadays, treatment strategies have been developed for the management of $\mathrm{AD}$ with the use of acetylcholinesterase (AChE) inhibitors (an enzyme principally involved in the hydrolysis of acetylcholine) (Jukic et al., 2007). Thymol $\left(\mathrm{EC}_{50}=0.74 \mathrm{mg} / \mathrm{mL}\right)$ was shown to possess acetylcholine esterase inhibitory activity but much less than its isomer carvacrol (Jukic et al., 2007). In elderly patients, $\mathrm{AD}$ is associated with oxidative stress, inflammation and it is also characterized by the deposition of amyloid beta (A $\beta$ ) proteins in the central nervous system (CNS) which results in the formation of amyloid plaques, neurofibrillary tangles and area specific neuronal loss and synaptic changes in the brain (Duyckaerts et al., 2009). Thymol (0.5-2 mg/kg) has been shown to inhibit cognitive impairments caused by increased $A \beta$ levels or cholinergic hypofunction in $\mathrm{A} \beta$ (25-35) or scopolamine treated rats attributed to its antioxidant, anti-inflammatory and anticholine esterase properties (Azizi et al., 2012). Thymol (0.39$25 \mu \mathrm{g} / \mathrm{mL}$ ) has been shown to inhibit $\mathrm{H}_{2} \mathrm{O}_{2}$ induced oxidative stress in PC-12 cells whereas thymol (100 and $1000 \mu \mathrm{g} / \mathrm{ml})$ also inhibited both $\mathrm{AChE}$ and butyrylcholinesterase (BChE) in a dose dependent manner (Lee et al., 2015).

\section{Anxiety}

It is one of the most common mental disorders that is characterized by a disturbance in mood or emotional tone due to excessive fear. Thymol (5-20 mg/kg) has been shown to promote anti-anxiety activity in mice on both elevated plus-maze (EPM) and light/dark exploration test (LDT) behavioral models. This effect of thymol could be due to the possible modulation of the 5-hydroxytryptamine (5-HT), $\gamma$-aminobutyric acid (GABA) and nitric oxide-cyclic guanosine $3^{\prime}, 5^{\prime}$-monophosphate (NO-cGMP) pathways (Bhandari and Kabra, 2014).

\section{Dementia}

Dietary supplementation of thymol $(42.5 \mathrm{mg} / \mathrm{kg})$ enhanced the status of endogenous antioxidants (SOD and GPx) and the proportion of PLs such as 18:2n-6, 20:1n-9, 22:4n-6 and 22:5n-3 in the aging rat brain (Youdim and Deans, 1999).

\section{Depression}

Depression is a life threatening illness and the changes induced by inflammatory cytokines in monoamine neurotransmitters is a primary pathway of depression (Miller and Timmie, 2009). Thymol (15 and $30 \mathrm{mg} / \mathrm{kg}$ ) has been shown to up regulate the levels of central neurotransmitters and inhibit the expressions of proinflammatory cytokines in unpredictable mild stress (CUMS) mice model (Deng et al., 2015).

\section{Epilepsy}

Epilepsy is a devastating neurological disease characterized by spontaneous recurrent seizures affecting millions of people all over the world (Bhutada et al., 2010). Thymol $(100 \mathrm{mg} / \mathrm{kg})$ decreased the duration of the hind limb extension (HLE) in maximal electroshock (MES)-induced seizures. In pentylenetetrazole (PTZ)-induced seizure model, thymol (100 mg/kg) prolonged the onset of myoclonic jerk, onset of clonic seizures, onset of HLE and onset of death. Thymol (50 and $100 \mathrm{mg} / \mathrm{kg}$ ) showed improved activity compared to diazepam in prolonging clonic seizure and the onset of myoclonic jerks. Furthermore, thymol (100 $\mathrm{mg} / \mathrm{kg})$ significantly prolonged the onset of death and reduced convulsions in the strychnine (STR) induced mouse model. Thymol (25 mg/kg, i.p.) significantly reduced seizure score, MDA levels and enhanced the levels of glutathione in the animal model of PTZ induced kindling (Sancheti et al., 2014). The authors revealed the antiepileptogenic potential of thymol by its $\mathrm{Na}^{+}$channel blocking effect, positive modulation of $\mathrm{GABA}_{\mathrm{A}}$ receptor and antioxidant property and they also concluded that it could be a potential candidate to treat epileptic patients (Sancheti et al., 2014). Thymol (10-50 mg/kg) attenuated PTZ (i.p. administration) induced epileptic stages in kindled rats via inhibiting oxidative stress markers in the serum MDA and with increased SOD activity. It also decreased the hippocampal pro-inflammatory cytokines viz. TNF- $\alpha$ and IL- $1 \beta$ released from astrocytes and microglia during and after the seizure induction in rats (Turrin and Rivest, 2004; Aliabadi et al., 2016). Thymol $\left(\mathrm{ED}_{50}=35.8 \mathrm{mg} / \mathrm{kg}\right)$ elicited inhibitory activity in the MES, sc Metrazol (scMET) and corneal-kindled models (Mishra and Baker, 2014).

\section{Cholinergic Dysfunction and Other Neurodegenerative Disorders}

Cholinergic dysfunction is manifested in a plethora of neurodegenerative and psychiatric disorders such as Alzheimers, Parkinsons, and Huntington's diseases. Thymol (10-100 ppm) in combination with gamma terpinene or para-cymene attenuated cholinergic dysfunction by enhancing synaptic levels of acetyl choline (Ach) and the responsiveness of nicotinic acetylcholine receptor (nAchR) in the Caenorhabditis elegans model (Sammi et al., 2016).

Thymol $(100 \mu \mathrm{M})$ was shown to possess GABAergic activity and it potentiates GABAA-mediated inhibition of synaptic transmission in vitro (Marin et al., 2011). Thymol (0$1 \mathrm{mM})$ enhanced GABA-induced $(5 \mathrm{mM})$ chloride influx at concentrations lesser than those revealing direct activity in the absence of GABA ( $\mathrm{EC}_{50}=12 \mu \mathrm{M}$ and $135 \mu \mathrm{M}$, respectively) in 
TABLE 5 | Effect of thymol in different experimental models of neurogenerative disorders.

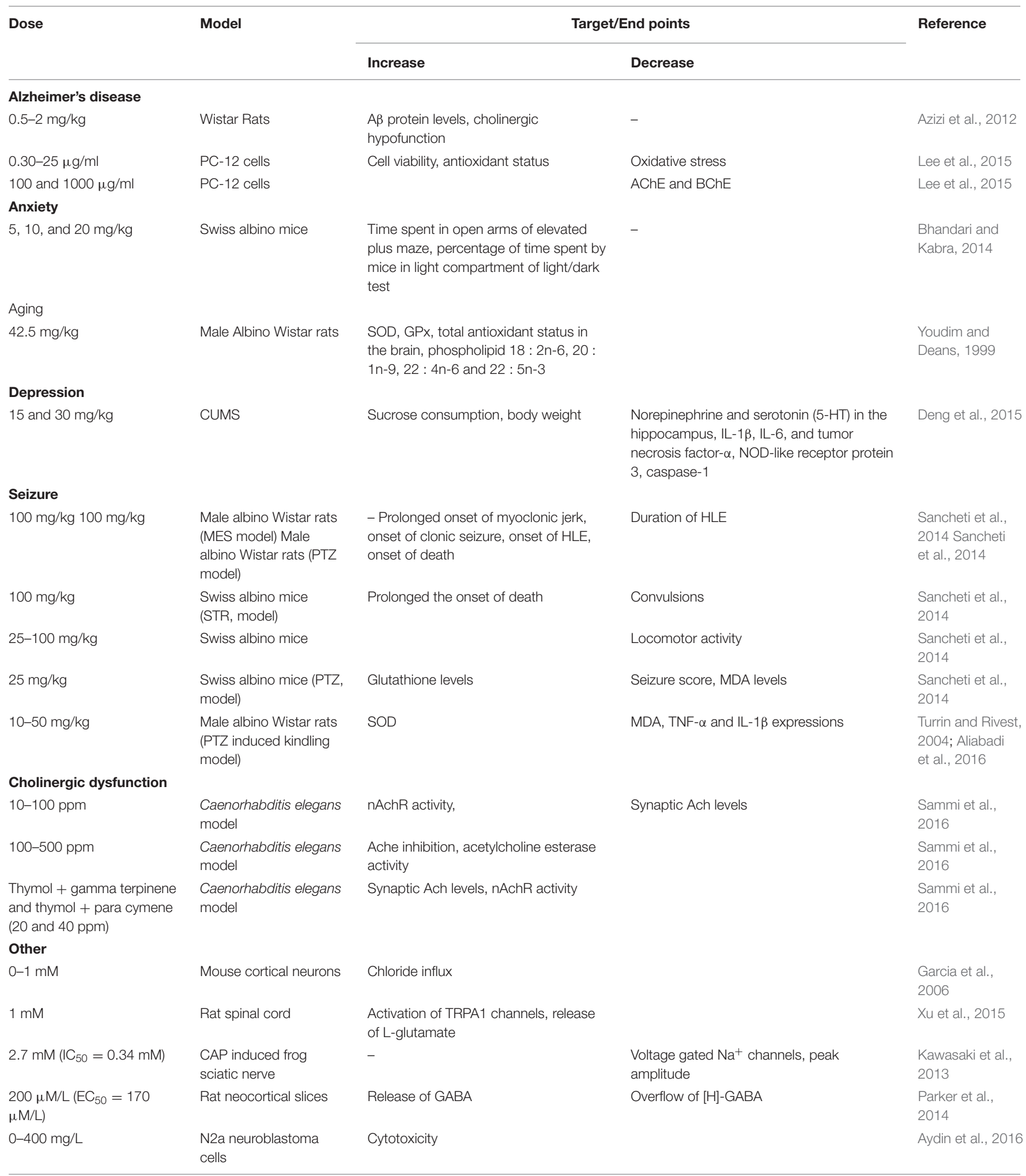

primary cultures of mouse cortical neurons (Garcia et al., 2006). A diet rich in thymol has been reported to enhance antioxidant defense and to maintain polyunsaturated fatty acid levels in aging rat brains (Youdim and Deans, 1999, 2000). Thymol has been reported to interact explicitly with synaptic neural functions and block the action of neuronal $\mathrm{Na}^{+}$channels (Haeseler et al., 2002). 
Thymol raised the action of chloride channels in oocytes and the cell lines expressing $\mathrm{GABA}_{\mathrm{A}}$ receptor subunits (Mohammadi et al., 2001; Priestley et al., 2003).

Recently, Sanchez et al. (2004) described the ability of thymol to integrate itself into the artificial membranes and enhance the binding affinity of $(3 \mathrm{H})$ flunitrazepam to $\mathrm{GABA}_{\mathrm{A}}$ receptors in synaptosomal membranes that is indicative of thymol's $\mathrm{GABA}_{\mathrm{A}}$ receptor agonist/modulator property. Thymol $(1 \mathrm{mM})$ has been shown to activate TRPAl channels and increase the frequent release of L-glutamate on substantia gelatinosa (SG) neurons while generating an outward current without transient receptor potential (TRP) activation in adult rat spinal cord slices by its potent antinoceptive effect (Xu et al., 2015). Thymol $(2.7 \mathrm{mM}) \quad\left(\mathrm{IC}_{50}=0.34 \mathrm{mM}\right)$ inhibited the peak amplitude in compound action potentials (CAP) in frog sciatic nerves (Kawasaki et al., 2013). Thymol $(200 \mu \mathrm{M})$ potentiated the release of $(3 \mathrm{H})$-GABA $\left(\mathrm{EC}_{50}=170 \mu \mathrm{M} / \mathrm{L}\right)$ probably by its antagonistic effect on $\mathrm{GABA}_{b}$ autoreceptors in rat neocortical slices (Parker et al., 2014). Thymol (0-400 mg/L) was shown to trigger cytotoxicity in N2a neuroblastoma cells (Aydin et al., 2016).

\section{THYMOL IN LUNG DISEASES}

The protective effects of thymol in pulmonary diseases are represented in Table 6.

\section{Asthma}

Asthma is an inflammatory disorder characterized by the infiltration of inflammatory cells into lung tissues, hypersecretion of the mucus by goblet cells, airway hypereactivity (AHR), Th2 mediated cytokines and their over-expressions including IL-4, IL-5 and interleukin-13 (IL-13) (Rogerio et al., 2010). Thymol $(4,8$, and $16 \mathrm{mg} / \mathrm{kg}$ ) has been shown to abrogate hyperresponsiveness (AHR) and allergic airway inflammation by attenuating infiltration of inflammatory cells, Th2 cytokines and ovalbumin (OVA)-specific IgE and suppressing the pathological changes due to its NF- $\mathrm{BB}$ activation blocking property in OVA-induced allergic mice (Zhou et al., 2014). Thymol $(0.7 \mu \mathrm{g} / \mathrm{ml} / \mathrm{kg})$ attenuated ovalbumin induced bronchial allergic asthma by inhibiting oxidative stress in male Wistar albino mice (Al-Khalaf, 2013). In OVA induced mice, thymol $(80 \mathrm{mg} / \mathrm{kg}$ ) suppressed the antigen-specific immune response by inducing reductions $\mathrm{T}_{\mathrm{H}}$ cells $\left[\mathrm{T}_{\mathrm{H}} 1, \mathrm{~T}_{\mathrm{H}} 2\right.$ and T-helper cell $\left.17\left(\mathrm{~T}_{\mathrm{H}} 17\right)\right]$ related cytokines and key transcription factors, revealed their potential to modulate over-activation of T-cells and the associated destructive immune responses (Gholijani and Amirghofran, 2016). Thymol (50 mg/kg) attenuated oxidative stress mediated bronchial asthma in OVA-Alum induced rat erythrocytes by increasing the status of antioxidants (Mottawie et al., 2011). These findings suggest that thymol possesses the potential to be used as an agent for therapeutic benefits in asthma. However, for the clinical usage, comprehensive safety and efficacy studies are further required (Zhou et al., 2014).
Thymol present in the leaf extract of Ocimum gratissimum Linn $(100,200$, and $400 \mathrm{mg} / \mathrm{kg}$ ) suppressed coughing in OVA induced bronchial asthma by reducing tracheal fluid secretion in rodents through its anti-asthmatic and antitussive effects (Ozolua et al., 2016). A previous report from Gavliakova et al. (2013) has revealed that nasal administration of thymol has been associated with the reduction of cough in asthma patients by an olfactory mechanism. Intake of one bronchipret (around $1.08 \mathrm{mg}$ of thymol) for about a month improved the compliance, pulmonary pressure and airway resistance in the lungs of horses (Van den Hoven et al., 2003). Thymol at higher concentrations $\left(10^{-4}-10^{-2} \mathrm{M}\right)$ showed bronchodilatory effects in guinea-pig tracheal preparations (Astudillo et al., 2014). Combined treatment with carvacrol/thymol $(200 \mu \mathrm{M}$, equal to $30 \mu \mathrm{g} / \mathrm{mL}$ ) inhibited the effects of chitin induced asthma by suppressing type 2-promoting release of cytokines and Src Homology 2 ( $\mathrm{SH} 2$ ) domain-containing inositol polyphosphate $5^{\prime}$ phosphatase 1 (SHIP1), toll like receptors (TLRs), cytokine signaling 1 (SOCS1) and micro RNAs expressions. It also reduced the toll like receptor 4 (TLR4), toll like receptor 2 (TLR2) protein levels and increased the SHIP1 and SOCS1 protein levels (negative regulators of total knee replacement (TKR) mediated immune response) in immortalized human bronchial epithelial cells (BEAS-2B cells). This study revealed the inhibitory effects of carvacrol/thymol treatment against chitin induced epithelial cell pro-inflammatory responses (Khosravi and Erle, 2016).

\section{Pleurism}

Thymol $(750 \mathrm{mg} / \mathrm{kg})$ has been shown to abrogate carrageenan induced pleurisy by inhibiting the accumulation of inflammatory exudates in the pleural cavity of the lungs (Fachini-Queiroz et al., 2012).

\section{THYMOL IN RADIATION INDUCED TOXICITY}

The protective effects of thymol in radiation-induced toxicity are represented in Table 7. Radiotherapy for the treatment of various cancers has been shown to induce serious damage to both tumors and normal cells. A report from Archana et al. (2011b) has revealed that thymol $(0-100 \mu \mathrm{g} / \mathrm{mL})$ diminished radiation-induced genotoxicity, apoptosis and necrosis in V79 cells primarily by the free radical scavenging and modulation of oxidative stress. Thymol treatment prevents the collapse of mitochondrial membrane potential (MMP) and protects the cells from apoptotic and necrotic cell death (Archana et al., 2011b). The radioprotective and anticlastogenic potential of a phenol derivative monoterpene thymol has been reported in whole-body gamma radiation induced Swiss albino mice (Archana et al., 2011a). The antioxidant, anticlastogenic and radioprotective potential of thymol is attributed to the stabilization of intracellular antioxidant levels and free radical scavenging activities by thymol (Archana et al., 2011a). The radioprotective potential of thymol is also demonstrated by increased LD50/30 by 
TABLE 6 | Effect of thymol in different experimental models of pulmonary diseases.

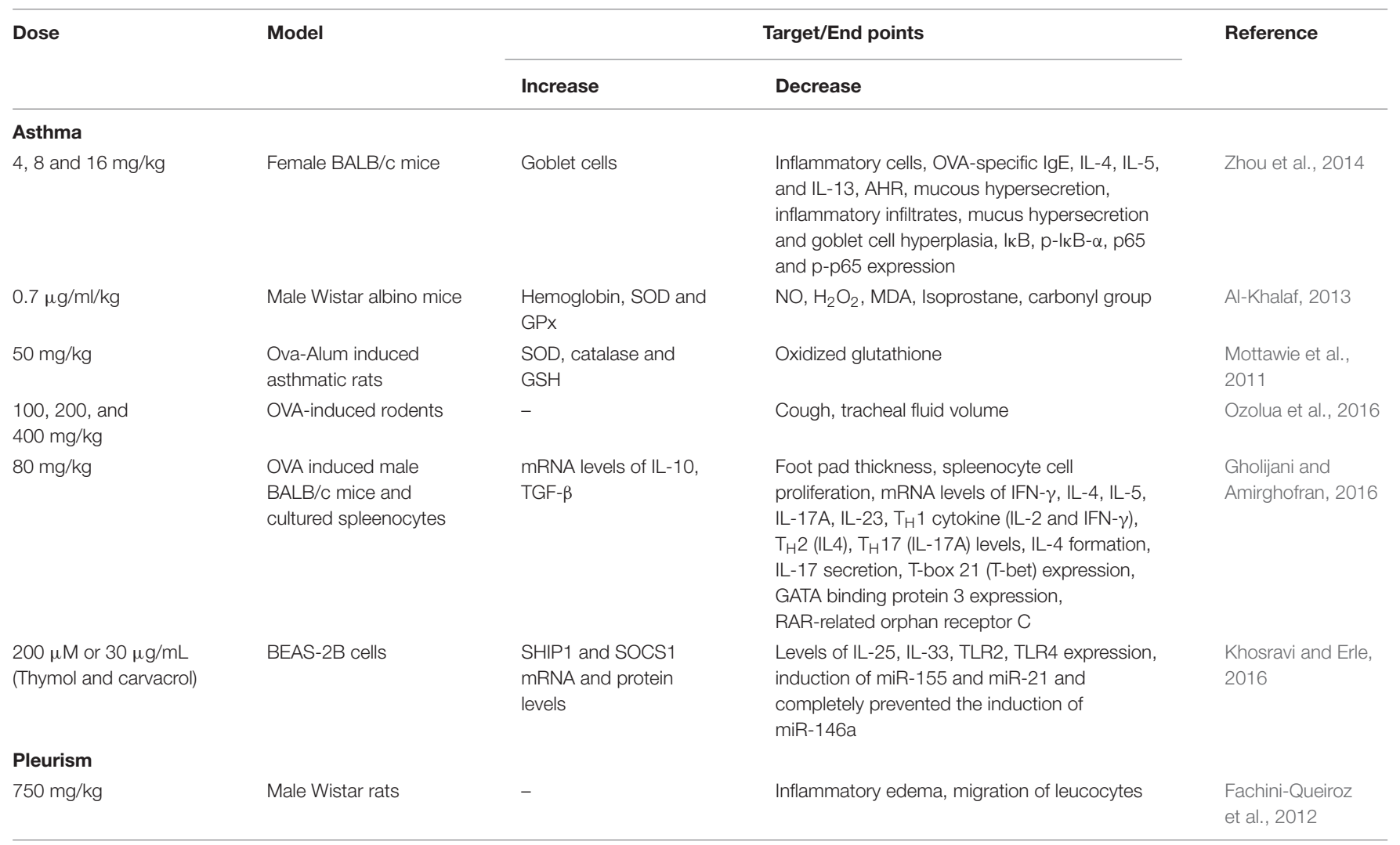

TABLE 7 | Effect of thymol on radiation toxicity.

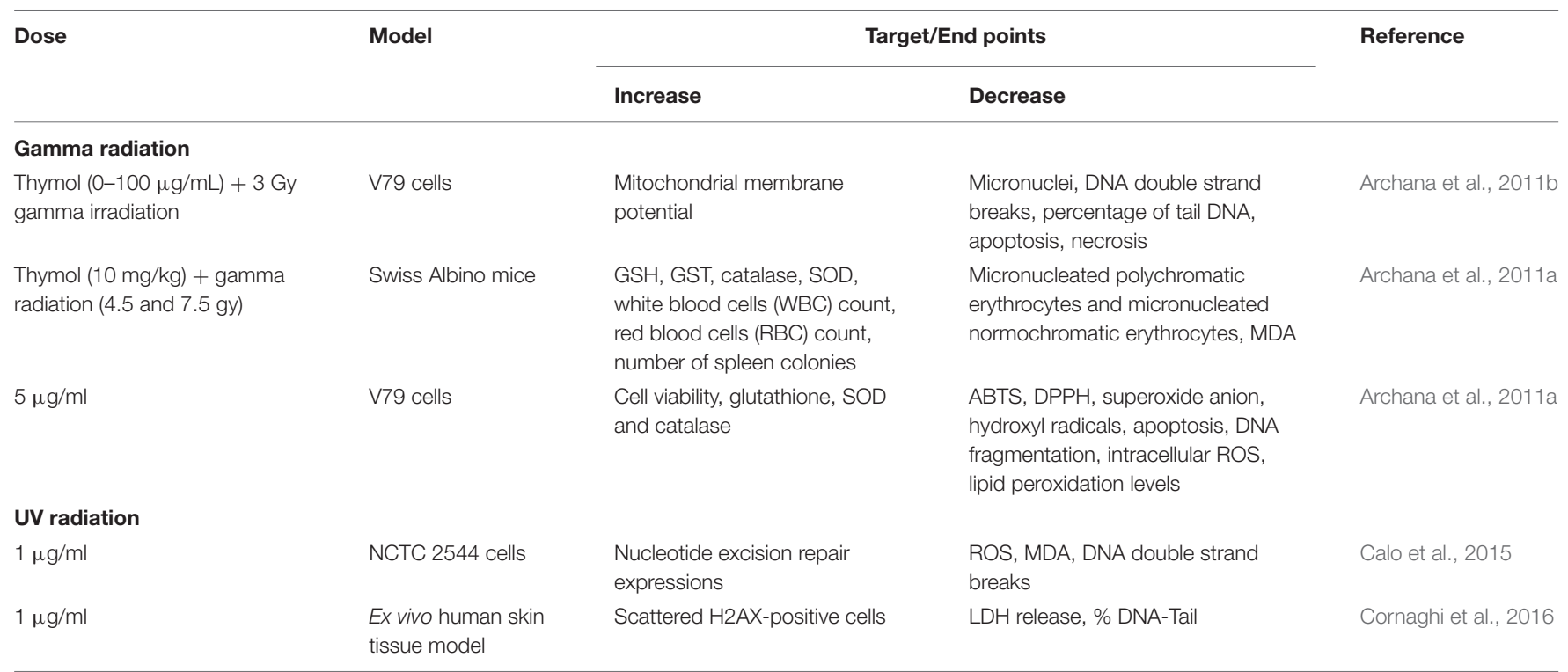

2.17 gray (Gy) which resulted in a dose reduction factor (DRF) of 1.25 (Archana et al., 2011a). Thymol (5 $\mu \mathrm{g} / \mathrm{ml})$ has been shown to abrogate radiation induced cytotoxicity by inhibiting the levels of lipid peroxidation and increasing the status of antioxidants in V79 cells grown in vitro (Archana et al., 2011a). Thymol (1 $\mu \mathrm{g} / \mathrm{ml})$ inhibited UV radiation A
(UVA) and UV radiation B (UVB) induced genotoxicity via inhibiting oxidative stress in the NCTC 2544 cell line (Calo et al., 2015). Thymol (1 $\mu \mathrm{g} / \mathrm{ml}$ ) attenuated UV radiation induced genotoxic damage in ex vivo human skin models by its potent anti-cancer properties (Cornaghi et al., 2016). 
TABLE 8 | Effect of thymol in different experimental models of autoimmune diseases, reproductive and metal induced toxicity.

\begin{tabular}{|c|c|c|c|c|}
\hline \multirow[t]{2}{*}{ Dose } & \multirow[t]{2}{*}{ Model } & \multicolumn{2}{|c|}{ Target/End points } & \multirow[t]{2}{*}{ Reference } \\
\hline & & Increase & Decrease & \\
\hline \multicolumn{5}{|l|}{ Rheumatoid arthritis } \\
\hline $100 \mathrm{mg} / \mathrm{kg}$ & Male Albino Wistar rats & SOD, catalase, GSH, & $\begin{array}{l}\text { TBARS, } \mathrm{NO} \text {, release of elastase, } \mathrm{Ca}^{2+} \\
\text { channels }\end{array}$ & $\begin{array}{l}\text { Braga et al., 2006; } \\
\text { Umar et al., } 2012\end{array}$ \\
\hline \multicolumn{5}{|l|}{ Osteoarthritis } \\
\hline $\begin{array}{l}\text { Diacerein and thymol } \\
(50+20.4 \mathrm{mg} / \mathrm{kg})\end{array}$ & $\begin{array}{l}\text { Male albino Wistar rats } \\
\text { (Rainsford's cold stress model) }\end{array}$ & $\begin{array}{l}\text { Lipophilicity, bioavailability, } \\
\text { absorption }\end{array}$ & $\begin{array}{l}\text { Oxidative stress, edema, ulcer index, } \\
\text { synovitis, cellular infiltration, bone } \\
\text { necrosis, connective tissue proliferation, } \\
\text { adjacent tissue involvement }\end{array}$ & $\begin{array}{l}\text { Dhaneshwar et al., } \\
2013\end{array}$ \\
\hline \multicolumn{5}{|l|}{ Other } \\
\hline $25 \mu \mathrm{g} / \mathrm{ml}$ & Jurkat leukemia cells & - & Levels of IL-2, IFN- $\gamma$, NFAT-2, c-FOS & Gholijani et al., 2015. \\
\hline \multicolumn{5}{|l|}{ Male infertility } \\
\hline $400 \mathrm{mg} / \mathrm{kg}$ & Male albino Wistar rats & Abnormal sperms & Sperm count, motility, testis weight & $\begin{array}{l}\text { Surendra Kumar et al., } \\
2011\end{array}$ \\
\hline $100-500 \mu \mathrm{g} / \mathrm{ml}$ & Human spermatozoa & Abnormal sperms & Sperm count, sperm motility and vitality, & Chikhoune et al., 2015 \\
\hline \multicolumn{5}{|c|}{ Chromium induced toxicity } \\
\hline $2.5 \mu \mathrm{g} / \mathrm{ml}$ & Isolated rat erythrocytes & SOD, catalase, GSH & $\begin{array}{l}\text { MDA, hemolysis, erythrocyte } \\
\text { destabilization }\end{array}$ & $\begin{array}{l}\text { Abd-Elhakim and } \\
\text { Mohamed, } 2016\end{array}$ \\
\hline \multicolumn{5}{|c|}{ Arsenic and mercury induced toxicity } \\
\hline $0-200 \mu \mathrm{M} / \mathrm{L}$ & Male Wistar rats & $\begin{array}{l}\text { Resting tension and mean } \\
\text { relaxation of aorta and trachea }\end{array}$ & $\begin{array}{l}\text { Aortic and tracheal contractions, ROS, } \\
\mathrm{Ca}^{2+} \text { influx }\end{array}$ & Kundu et al., 2016 \\
\hline $100 \mu \mathrm{M}$ & $\mathrm{HgCl}_{2}$ induced HepG2 cells & $\begin{array}{l}\text { Cell viability, mitochondrial } \\
\text { membrane potential, SOD, } \\
\text { catalase and GSH levels }\end{array}$ & $\begin{array}{l}\text { Mirconucleated binucleated cell } \\
\text { frequency, micronucleous frequency, } \\
\text { percentage of tail DNA, DNA damage, } \\
\text { apoptosis, necrosis, ROS generation, } \\
\text { superoxide radicals, MDA levels }\end{array}$ & Shettigar et al., 2015 \\
\hline
\end{tabular}

\section{THYMOL IN AUTOIMMUNE DISEASES}

The protective effect of thymol against autoimmune diseases is represented in Table 8. Rheumatoid arthritis, an autoimmune disease is characterized by chronic and progressive inflammation of the synovial joints and erosive destruction of the articular tissue (Feldmann et al., 1996; Feldmann, 2002; Choi et al., 2009). Thymol $(100 \mathrm{mg} / \mathrm{kg})$ was shown to inhibit collagen induced arthritis by decreasing lipid peroxidation mediated oxidative stress by increasing the status of antioxidants in male Wistar rats. Thymol also stopped the activity of elastase, a marker for collagen degradation and prevented the invasion of inflammatory cells to the injured site by blocking the $\mathrm{Ca}^{2+}$ channels (Braga et al., 2006; Umar et al., 2012). The physical mixture of diacerein and thymol (DTH) $(50+20.4 \mathrm{mg} / \mathrm{kg})$ abrogated Freund's complete adjuvant (FCA) induced arthritis in male albino Wistar rats. This combined treatment decreased oxidative stress, ulcer index and synovitis in arthritic rats by its potent antioxidant property. DTH administration also improved the histoarchitecture as evidenced by decreased necrosis in bones, cellular infiltration, connective tissue proliferation and the involvement of adjacent tissues (Dhaneshwar et al., 2013). In Jurkat leukemia cells as an in vitro $\mathrm{T}$ cell model, thymol $(25 \mu \mathrm{g} / \mathrm{ml})$ modulated T-cell activity by reducing IL- 2 and IFN- $\gamma$ production via down regulation of AP-1 and nuclear factors of activated T-2 (NFAT2) transcription factors showing its capacity in reducing the overactivity of T-cells in immune mediated diseases (Gholijani et al., 2015).

\section{THYMOL IN REPRODUCTIVE DISORDERS}

The protective effects of thymol in reproductive disorders are represented in Table 8.

\section{Contraceptive}

Male infertility refers to the inability of males to cause pregnancy in females usually due to reduced sperm quantity and quality (Cooper et al., 2009). Thymol (400 mg/kg) decreased fertility in male albino Wistar rats. Thymol decreased the weight of testis, sperm count and motility and increased the amount of abnormal sperms in rat testis (Surendra Kumar et al., 2011). Chikhoune et al. (2015) revealed the anti-fertility effect of thymol in human spermatozoa. Thymol (100-500 $\mu \mathrm{g} / \mathrm{ml})$ dose dependently decreased sperm count, sperm motility, sperm vitality in human sperm. These two studies have revealed that thymol could be used as a standard contraceptive agent in humans.

\section{THYMOL IN METAL INDUCED TOXICITY}

The protective effects of thymol in metal induced toxicity are represented in Table 8.

\section{Chromium}

Chromium is a naturally occurring, highly toxic transition metal due to its strong ability to oxidize cellular components 
through its passive entry via cellular membranes into cells (O'Brien et al., 2003). Thymol $(2.5 \mu \mathrm{g} / \mathrm{ml})$ has been shown to inhibit hexavalent chromium induced oxidative damage in rat erythrocytes. Thymol treatment significantly decreased MDA levels, hemolysis, erythrocyte destabilization and increased the activities of antioxidants enzymes and improved the levels of glutathione in rat erythrocytes (Abd-Elhakim and Mohamed, 2016).

\section{Arsenic and Mercury}

Arsenic and mercury are toxic metals found in nature in soil, in industrial and agrochemicals as well as pharmaceuticals. Upon exposure, they are known to cause acute and chronic disease and mainly affect smooth muscles of the cardiovascular and respiratory systems. Thymol (0-200 $\mu \mathrm{M} / \mathrm{L})$ abrogated arsenic and mercury induced hyper contraction of both aortic and tracheal smooth muscles by inhibiting $\mathrm{Ca}^{2+}$ influx at low concentrations. It also neutralizes ROS and inhibits $\mathrm{Ca}^{2+}$ influx at higher concentrations (Kundu et al., 2016). Thymol (100 $\mu \mathrm{M})$ was shown to protect against cytotoxicity and genotoxicity induced by mercuric chloride in the human HepG2 cell line due to its potent free radical scavenging ability that in reflected in the attenuation of mitochondrial and oxidative damage (Shettigar et al., 2015). Thymol present in the essential oil of T. lanceolatus $\left(\mathrm{IC}_{50}=256.17 \mu \mathrm{g} / \mathrm{ml}\right.$ ) was shown to induce cytotoxicity and cell proliferation in HepG2 cells (Khadir et al., 2016).

\section{PHARMACEUTICAL DEVELOPMENT OF THYMOL}

Nowadays, the focus on natural products is to develop their formulation with improved bioavailability, favorable pharmacokinetics and minimal adverse effects. Various attempts have also been made to develop thymol formulation with improved drug delivery options for the treatment of various human diseases. The pharmacokinetic and physiochemical properties of thymol including absorption, bioavailability, elimination rate, solubility are the major barricades in the drug design and delivery of thymol. There are lot of techniques such as structural modification (Mastelic et al., 2008), microparticles using cellular derivatives (Zamani et al., 2015), encapsulation (Rassu et al., 2014), solid dispersion (Roost et al., 2015), complexations (Nieddu et al., 2014) and nanoparticle formulation (Pan et al., 2014; Zhang et al., 2014) which could pave the way to advance drug delivery options for thymol and these are mentioned below.

\section{STRUCTURAL MODIFICATION FOR FUTURE DRUG DEVELOPMENT}

The structural alterations into the phenol structures, like introducing a polar hydroxymethyl moiety, could enhance its antioxidant activity compared to parent compounds (Torres de Pinedo et al., 2007). The derivative of thymol, named 4(hydroxymethyl)-2-isopropyl-5-methylphenol, was synthesized by the hydroxymethylation of thymol (Mastelic et al., 2008). The phenolates as nucleophiles reacted with methanol which yielded hydroxymethylphenols at alkaline $\mathrm{pH}$. This might be due to the delocalization of the phenolate ion charge between the phenolate oxygen and its respective ortho and para- carbons. The steric effect of the isopropyl group was believed to confer improved antioxidant activity and reduced mitochondrial activity of thymol derivative in HeLa cells in a concentration dependent manner (Mastelic et al., 2008).

A set of new thymol derivatives invented and patented recently showed potent antitumor activity against A549, SKOV-3, human melanoma cells (SK-MEL-2), cellosaurus cells (XF498) and colorectal adenocarcinoma cells (HCT15 cells) (Zee et al., 2001). Thymol analogues such as 4-morpholinomethyl-2-isopropyl-5methylphenol (THMO) and 4-Pyrrolidinomethyl-2-isopropyl-5methylphenol (THPY) were synthesized by the reaction between thymol and formaldehyde with morpholine or pyrrolidine (Shen et al., 2005). These two analogs of thymol showed a potent superoxide anion scavenging effect in vitro and in human blood neutrophils and also possess a superior lipid peroxidation inhibitory effect via the attenuation of enzymes involved in antioxidant defense. In the two thymol analogs, THMO revealed potent antioxidant activity with $\mathrm{IC}_{50}$ values of 21.72 and $61.29 \mu \mathrm{M}$ for the inhibition of xanthine oxidase and lipid peroxidation (Shen et al., 2005). THMO (10 mM) also decreased the peak amplitude of L-type inward current of $\mathrm{Ca}^{2+}\left(\mathrm{I}_{\mathrm{Ca}, \mathrm{L}}\right)$ in NG108-15 cells as analyzed by the patch-clamp technique. These reports have revealed that the antioxidative action of the thymol analogs is linked with its capacity of inhibiting $\mathrm{Ca}^{2+}$ current (Shen et al., 2005). This study suggests that THMO could be a suitable candidate for the treatment of free radical related disorders by virtue of its antioxidant and $\mathrm{Ca}^{2+}$ ion current inhibition activity.

\section{MICROENCAPSULATION FOR DRUG DELIVERY}

Microencapsulation is a tool frequently used in pharmaceutical, food, cosmetic, and agrochemical industries. The encapsulation of thymol in microspheres made up of natural polymers such as methylcellulose and hydroxylpropyl methylcellulose phthalate can serve to obtain efficient delivery of this phytochemical as adjuvants or current medications for the treatment of infectious diseases and compensate the limited bioavailability due to its lower solubility (Rassu et al., 2014). The core-shell or matrix particle encapsulation of essential oils has been investigated to determine their controlled release (Martins et al., 2014). The encapsulation of thymol into methylcellulose microspheres by spray drying remarkably increases the bioavailability compared to free thymol and it can be suggested to be used for the treatment of intestinal infections (Rassu et al., 2014).

The synthetic, natural and semisynthetic polymers play a crucial role in drug release formulations and nowadays these are used as efficient drug carriers (Nayak et al., 2009). Cellulose derivatives have been used for sustained release matrices, delayed release dosage forms, binders in granules and tablets and they 
also have many other applications (Chambin et al., 2004). Zamani et al. (2015) has structured the matrix polymer encapsulation of thymol by the emulsion solvent evaporation method with hydroxy propyl methyl cellulose (HPMC) and ethyl cellulose (EC) to increase the duration of action of thymol. Both polymers have shown a considerable effect on drug release behavior, efficiency of drug entrapment, drug loading and particle size, whereas the formulation F6 revealed a controlled effect compared to the other formulations in in vitro release (Zamani et al., 2015).

\section{CO-ADMINISTRATION FOR DRUG DELIVERY}

A co-drug DTH has been developed recently by Dhaneshwar et al. (2013). Diacerein, an IL-1 $\beta$ inhibitor possesses anti-arthritic and moderate anti-inflammatory properties (Dhaneshwar et al., 2013). This mutual prodrug was developed by the covalent linkage of thymol with the carboxylic acid $(-\mathrm{COOH})$ group of diacerein and this prodrug showed lessened irritant effect, improved absorption, prolonged drug release with improved anti-inflammatory effect. The hydrophobic nature of thymol enhanced the lipophilicity of diacerein which could be responsible for its enhanced bioavailability and its better absorption. The synthesis of DTH was done by the dicyclohexylcarbodiimide (DCC) coupling method (Holmberg and Hansen, 1979) and its physicochemical characterization was evaluated using spectral analysis. DTH was very stable in acidic $\mathrm{pH}$ conditions of the stomach and complete diacerein release was observed in phosphate buffer (91-94\%) (pH 7.4) and in the small intestine.

Thymol has been used as an antioxidant agent in this design and its selection was justified after the promising anti-inflammatory and anti-arthritic effect of DTH against osteoarthritis compared to standard drugs which is attributed to the pharmacological effects of thymol. DTH attenuated FCA induced chronic synovitis in rats by its marked antiarthritic effect compared to the moderate effect of diacerein and mild effect of thymol. The authors suggested that the combination of diacerein with thymol could be promising therapeutic approach in inflammation related diseases (Dhaneshwar et al., 2013).

\section{CONCLUDING REMARKS}

The need for alternative therapies with less toxic effects for various human ailments is evident. The findings from various studies reviewed herein showed the role of thymol in the prevention of various types of diseases through its multipharmacological properties from antioxidant to anti-tumor ones.

\section{REFERENCES}

Abd-Elhakim, Y. M., and Mohamed, W. A. M. (2016). Assessment of the role of thymol in combating chromium (VI)-induced oxidative stress in isolated rat erythrocytes in vitro. Toxicol. Environ. Chem. 98, 1227-1240. doi: 10.1080/ 02772248.2015 .1121490
Thymol containing plants have been used in traditional medicine for management of various diseases such as many cancer types, cardiovascular diseases, diabetes, and neurodegenerative diseases. Multiple pharmacological and molecular mechanisms of action for its preventive and therapeutic effects have been demonstrated based on its molecular targets identified in numerous studies. While a great number of in vitro studies for numerous diseases including cancer and cardiovascular diseases have been reported, more in vivo studies should be undertaken to confirm the in vitro findings. In addition, there is a contradiction between in vitro concentrations and in vivo doses in certain types of cancer. Thus, pharmacokinetics and pharmaceutical studies are needed to interpret the inconsistency between in vitro and in vivo results. These reported features along with the minimal side effects, cost effectiveness and easy access made thyme and its constituent thymol an effective therapeutic agent for the management of numerous chronic diseases. Furthermore, thymol, being abundantly and ubiquitously present in numerous plants, could be available for dietary use. Its administration and benefits could be achieved in a simpler way through normal daily diet. However, the vast majority of the data is preclinical, and further clinical studies are warranted. Furthermore, comprehensive toxicological studies should be conducted to support the safety of thymol in animal models to progress for clinical studies. Though, taking together all the studies, it is significant to say that research on thymol as a drug candidate is progressive and encouraging. This has been well demonstrated by the publication patterns year after year. Hence, thymol is one of the most powerful contenders in the race of phytochemicals of natural origin with polypharmacological properties displaying potent preventive and therapeutic properties against various human diseases.

\section{AUTHOR CONTRIBUTIONS}

SO and MN conceptualized and outlined the study. MN drafted the manuscript. HAT, SA, HJ, and SO edited and reviewed the manuscript. SO and MN throughly re-reviewed it and all authors approved it.

\section{ACKNOWLEDGMENTS}

The research in laboratory of Shreesh Ojha is supported by the University Program for Advanced Research (UPAR) and CenterBased Interdisciplinary grants from the Office of the Deputy Vice Chancellor of Research and Graduate Studies of United Arab Emirates University, Al Ain, UAE.

Aboelwafa, H. R., and Yousef, H. N. (2015). The ameliorative effect of thymol against hydrocortisone-induced hepatic oxidative stress injury in adult male rats. Biochem. Cell Biol. 93, 282-289. doi: 10.1139/bcb-20140154

Aeschbach, R., Loliger, J., Scott, B. C., Murcia, A., Butler, J., Halliwell, M., et al. (1994). Antioxidant actions of thymol, carvacrol, 6-gingerol, zingerone and 
hydroxytyrosol. Food Chem. Toxicol. 32, 31-36. doi: 10.1016/0278-6915(84) 90033-4

Aftab, K., Atta-Ur-Rahman, and Usmanghani, K. (1995). Blood pressure lowering action of active principle from Trachyspermum ammi (L.) Sprague. Phytomedicine 2, 35-40. doi: 10.1016/S0944-7113(11)80046-2

Aghamohammadi, A., Hosseinimehr, S. J., Ghasemi, A., Azadbakht, M., and Pourfallah, T. A. (2015). Radiosensitization effects of a Zataria multiflora extract on human glioblastoma cells. Asian Pac. J. Cancer Prev. 16, 7285-7290. doi: 10.7314/APJCP.2015.16.16.7285

Ahmadifar, E., Falahatkar, B., and Akrami, R. (2011). Effects of dietary thymolcarvacrol on growth performance, hematological parameters and tissue composition of juvenile rainbow trout, Oncorhynchus mykiss. J. Appl. Ichthyol. 27, 1057-1060. doi: 10.1111/j.1439-0426.2011.01763.x

Alam, K., Nagi, M. N., Badary, O. A., Al-shabanah, O. A., Al-Rikabi, A. C., and Al-Bekairi, A. M. (1999). The protective action of thymol against carbon tetrachloride hepatotoxicity in mice. Pharmacol. Res. 40, 159-163. doi: 10.1006/ phrs.1999.0472

Aliabadi, A., Izadi, M., and Rezvani, M. E. (2016). Esmaeili-dehaj, M. Effects of thymol on serum biochemical and antioxidant indices in kindled rats. Int. J. Med. Lab. 2016, 43-49.

Alinezhad, H., Azimi, R., Zare, M., Ebrahimzadeh, M. A., Eslami, S., Nabavi, S. F., et al. (2013). Antioxidant and antihemolytic activities of ethanolic extract of flowers, leaves, and stems of Hyssopus officinalis L. var. angustifolius. Int. J. Food Prop. 16, 1169-1178. doi: 10.1080/10942912.2011.578319

Al-Khalaf, M. I. (2013). Thyme and thymol effects on induced bronchial asthma in mice. Life Sci. J. 10, 693-699.

Al-Malki, A. L. (2010). Antioxidant properties of thymol and butylated hydroxytoluene in carbon tetrachloride -induced mice liver injury. JKAU 22, 239-248. doi: 10.4197/Sci.22-1.16

Aman, S., Moin, S., Owais, M., and Siddiqui, M. U. (2013). Antioxidant activity of thymol: protective role in AAPH-induced hemolysis in diabetic erythrocytes. Int. J. Pharm. Sci. Invent. 2, 55-60.

Amandi, R., Hyde, J. R., Ross, S. K., Lotz, T. J., and Poliakoff, M. (2005). Continuous reactions in supercritical fluids; a cleaner, more selective synthesis of thymol in supercritical CO2. Green Chem. 7, 288-293. doi: 10.1039/b418983c

Amirghofran, Z., Ahmadi, H., Karimi, M. H., Kalantar, F., Gholijani, N., and Malek-Hosseini, Z. (2016). In vitro inhibitory effects of thymol and carvacrol on dendritic cell activation and function. Pharm. Biol. 54, 125-132. doi: 10.3109/ 13880209.2015.1055579

Amirghofran, Z., Hashemzadeh, R., Javidnia, K., Golmoghaddam, H., and Esmaeilbeig, A. (2011). In vitro immunomodulatory effects of extracts from three plants of the Labiatae family and isolation of the active compound(s). J. Immunotoxicol. 8, 265-273. doi: 10.3109/1547691X.2011.590828

Amiri, H. (2012). Essential oils composition and antioxidant properties of three Thymus species. Evid. Based Complement. Alternat. Med. 2012:728065. doi: 10.1155/2012/728065

Anamura, S. I. (1989). Effects of phenolic dental medicaments on arachidonic arachidonic acid metabolism and their antiinflammatory action. Hiroshima Daigaku Shigaku Zasshi. 21, 147-162.

Anderson, R. C., Krueger, N. A., Genovese, K. J., Stanton, T. B., Mackinnon, K. M., Harvey, R. B., et al. (2012). Effect of thymol or diphenyliodonium chloride on performance, gut fermentation characteristics, and Campylobacter colonization in growing swine. J. Food Prot. 75, 758-761. doi: 10.4315/0362-028X.JFP11-390

Arab, H. A., Fathi, M., Mortezai, E., and Hosseinimehr, S. J. (2015). Chemoprotective effect of thymol against genotoxicity induced by bleomycin in human lymphocytes. Pharm. Biomed. Res. 1, 26-31. doi: 10.18869/acadpub. pbr.1.1.26

Arai, T. (1988). Cytotoxicity of thymol on cultured mammalian cells. Shigaku 76, 24-35.

Araujo, L. X., Novato, T. P., Zeringota, V., Matos, R. S., Senra, T. O., Maturano, R., et al. (2015). Acaricidal activity of thymol against larvae of Rhipicephalus microplus (Acari: Ixodidae) under semi-natural conditions. Parasitol. Res. 114, 3271-3276. doi: 10.1007/s00436-015-4547-3

Archana, P. R., Nageshwar Rao, B., and Satish Rao, B. S. (2011a). In vivo radioprotective potential of thymol, a monoterpene phenol derivative of cymene. Mutat. Res. 726, 136-145. doi: 10.1016/j.mrgentox.2011. 08.007
Archana, P. R., Nageshwar Rao, B., and Satish Rao, B. S. (2011b). Modulation of gamma ray-induced genotoxic effect by thymol, a monoterpene phenol derivative of cymene. Integr. Cancer Ther. 10, 374-383. doi: 10.1177/ 1534735410387421

Astudillo, A., Hong, E., Bye, R., and Navarrete, A. (2014). Antispasmodic activity of extracts and compounds of Acalypha phleoides Cav. Phytother. Res. 18, 102-106. doi: $10.1002 /$ ptr. 1414

Austgulen, L. T., Solheim, E., and Scheline, R. R. (1987). Metabolism in rats of p-cymene derivatives: carvacrol and thymol. Pharmacol. Toxicol. 61, 98-102. doi: 10.1111/j.1600-0773.1987.tb01783.x

Aydin, E., Taşdemir, S., Hacimuftuoglu, F., and Turkez, H. (2016). Anticancer, antioxidant and cytotoxic potential of thymol in vitro brain tumor cell model. Cent. Nerv. Syst. Agents Med. Chem. doi: 10.2174/1871524916666160823121854 [Epub ahead of print].

Aydin, S., Başaran, A. A., and Başaran, N. (2005). The effects of thyme volatiles on the induction of DNA damage by the heterocyclic amine IQ and mitomycin C. Mutat. Res. 2005, 43-53. doi: 10.1016/j.mrgentox.2004.10.017

Azirak, S., and Rencuzogullari, E. (2008). The in vivo genotoxic effects of carvacrol and thymol in rat bone marrow cells. Environ. Toxicol. 23, 728-735. doi: 10. 1002/tox. 20380

Azizi, Z., Ebrahimi, S., Saadatfar, E., Kamalinejad, M., and Majlessi, N. (2012). Cognitive- enhancing activity of thymol and carvacrol in two rat models of dementia. Behav. Pharmacol. 23, 241-249. doi: 10.1097/FBP.0b013e3283534301

Bairwa, R., Sodha, R. S., and Rajawat, B. S. (2012). Trachyspermum ammi. Pharmacogn. Rev. 6, 56-60. doi: 10.4103/0973-7847.95871

Beer, A. M., Lukanov, J., and Sagorchev, P. (2007). Effect of thymol on the spontaneous contractile activity of the smooth muscles. Phytomedicine 14, 65-69. doi: 10.1016/j.phymed.2006.11.010

Begrow, F., Engelbertz, J., Feistel, B., Lehnfeld, R., Bauer, K., and Verspohl, E. J. (2010). Impact of thymol in thyme extracts on their antispasmodic action and ciliary clearance. Planta Med. 76, 311-318. doi: 10.1055/s-0029-1186179

Bertevello, P. L., Logullo, A. F., Nonogaki, S., Campos, F. M., Chiferi, V., Alves, C. C., et al. (2005). Immunohistochemical assessment of mucosal cytokine profile in acetic acid experimental colitis. Clinics 60, 277-286. doi: 10.1590/ S1807-59322005000400004

Bhandari, S. S., and Kabra, M. P. (2014). To evaluate anti-anxiety activity of thymol. J. Acute Dis. 3, 136-140. doi: 10.1016/S2221-6189(14)60030-5

Bhatia, K. S., and Singh, J. (1998). Mechanism of transport enhancement of LHRH through porcine epidermis by terpenes and iontophoresis: permeability and lipid extraction studies. Pharm. Res. 15, 1857-1862. doi: 10.1023/A: 1011906022903

Bhutada, P., Mundhada, Y., Bansod, K., Dixit, P., Umathe, S., and Mundhada, D. (2010). Anticonvulsant activity of berberine, an isoquinoline alkaloid in mice. Epilepsy Behav. 18, 207-210. doi: 10.1016/j.yebeh.2010.03.007

Boudry, G., and Perrier, C. (2008). Thyme and cinnamon extracts induce anion secretion in piglet small intestine via cholinergic pathways. J. Physiol. Pharmacol. 59, 543-552.

Braga, P. C., Dal Sasso, M., Culici, M., Bianchi, T., Bordoni, L., and Marabini, L. (2006). Anti- inflammatory activity of thymol: inhibitory effect on the release of human neutrophil elastase. Pharmacology 77, 130-136. doi: 10.1159/000093790

Bukovska, A., Cikos, S., Juhas, S., Ilkova, G., Rehak, P., and Koppel, J. (2007). Effects of a combination of Thyme and Oregano essential oils on TNBS-induced colitis in mice. Mediators Inflamm. 2007:23296. doi: 10.1155/2007/23296

Cabello, M. L. R., Praena, D. G., Puerto, M., Silvia Pichardo, S., Jos, A., and Camean, A. M. (2015). In vitro pro-oxidant/antioxidant role of carvacrol, thymol and their mixture in the intestinal Caco-2 cell line. Toxicol. In Vitro 29, 647-656. doi: 10.1016/j.tiv.2015.02.006

Calo, R., Visone, C. M., and Marabini, L. (2015). Thymol and Thymus vulgaris L. activity against UVA- and UVB-induced damage in NCTC 2544 cell line. Mutat. Res. 791, 30-37. doi: 10.1016/j.mrgentox.2015.07.009

Cardoso, E. S., Santana, T. A., Diniz, P. B., Montalvao, M. M., Bani, C. C., and Thomazzi, S. M. (2016). Thymol ameliorates inflammatory response and accelerates regeneration in cardiotoxin-induced muscle injury. J. Pharm. Pharmacol. 68, 352-360. doi: 10.1111/jphp.12520

Chambin, O., Champion, D., Debray, C., Rochat-Gonthier, M. H., Le Meste, M., and Pourcelot, Y. (2004). Effects of different cellulose derivatives on drug release mechanism studied at a preformulation stage. J. Control. Release 95, 101-108. doi: 10.1016/j.jconrel.2003.11.009 
Chang, H. T., Chou, C. T., Liang, W. Z., Lu, T., Kuo, D. H., Shieh, P., et al. (2014). Effects of thymol on $\mathrm{Ca} 2+$ homeostasis and apoptosis in MDCK renal tubular cells. Chin. J. Physiol. 57, 90-98. doi: 10.4077/CJP.2014.BAB192

Chang, H. T., Hsu, S. S., Chou, C. T., Cheng, J. S., Wang, J. L., Lin, K. L., et al. (2011). Effect of thymol on Ca2 + homeostasis and viability in MG63 human osteosarcoma cells. Pharmacology 88, 201-212. doi: 10.1159/000331864

Chang, Y. C., Tai, K. W., Huang, F. M., and Huang, M. F. (2000). Cytotoxic and nongenotoxic effects of phenolic compounds in human pulp cell cultures. J. Endod. 26, 440-443. doi: 10.1097/00004770-200008000-00002

Chauhan, A. K., Jakhar, R., Paul, S., and Kang, S. C. (2014). Potentiation of macrophage activity by thymol through augmenting phagocytosis. Int. Immunopharmacol. 18, 340-346. doi: 10.1016/j.intimp.2013.11.025

Chauhan, A. K., and Kang, S. C. (2015). Therapeutic potential and mechanism of thymol action against ethanol induced gastric mucosal injury in rat model. Alcohol 49, 739-745. doi: 10.1016/j.alcohol.2015.08.004

Chauhan, P. S., Satti, N. K., Suri, K. A., Amina, M., and Bani, S. (2010). Stimulatory effects of Cuminum cyminum and flavonoid glycoside on Cyclosporine-A and restraint stress induced immune-suppression in Swiss albino mice. Chem. Biol. Interact. 185, 66-72. doi: 10.1016/j.cbi.2010.02.016

Chikhoune, A., Stouvenel, L., Iguer-Ouada, M., Hazzit, M., Schmitt, A., Lores, P., et al. (2015). In vitro effects of Thymus munbyanus essential oil and thymol on human sperm motility and function. Reprod. Biomed. Online 31, 411-420. doi: 10.1016/j.rbmo.2015.06.011

Choi, J. H., Kim, S. W., Yu, R., and Yun, J. W. (2016). Monoterpene phenolic compound thymol promotes browning of 3T3-L1 adipocytes. Eur. J. Nutr. doi: 10.1007/s00394-016-1273-2 [Epub ahead of print] doi: 10.1007/s00394016-1273-2

Choi, Y., Arron, J. R., and Townsend, M. J. (2009). Promising bone related therapeutic targets for rheumatoid arthritis therapy. Nat. Rev. Rheumatol. 5, 543-548. doi: 10.1038/nrrheum.2009.175

Colombo, M., Priori, D., Gandolfi, G., Boatto, G., Nieddu, M., Bosi, P., et al. (2014). Effect of free thymol on differential gene expression in gastric mucosa of the young pig. Animal 8, 786-791. doi: 10.1017/S1751731114000172

Cooper, T. G., Noonan, E., Von Eckardstein, S., Auger, J., Baker, H. W., Behre, H. M., et al. (2009). World Health Organization reference values for human semen characteristics. Hum. Reprod. Update 16, 231-245. doi: 10.1093/ humupd/dmp048

Cornaghi, L., Arnaboldi, F., Calo, R., Landoni, F., Preis, W. F. B., Marabini, L., et al. (2016). Effects of UV rays and thymol/ Thymus vulgaris L. Extract in an ex vivo human skin model: morphological and genotoxicological assessment. Cells Tissues Organs 201, 180-192. doi: 10.1159/000444361

de Morais, S. M., Vila-Nova, N. S., Bevilaqua, C. M., Rondon, F. C., Lobo, C. H., de Alencar Araripe Noronha Moura, A., et al. (2014). Thymol and eugenol derivatives as potential antileishmanial agents. Thymol and eugenol derivatives as potential antileishmanial agents. Bioorg. Med. Chem. 22, 6250-6255. doi: 10.1016/j.bmc.2014.08.020

Demirci, F., Paper, D. H., Franz, G., and Baser, K. H. (2004). Investigation of the Origanum onites L. essential oil using the chorioallantoic membrane (CAM) assay. J. Agric. Food Chem. 52, 251-254. doi: 10.1021/jf034850k

Deng, X. Y., Li, H. Y., Chen, J. J., Li, R. P., Qu, R., Fu, Q., et al. (2015). Thymol produces an antidepressant-like effect in a chronic unpredictable mild stress model of depression in mice. Behav. Brain Res. 291, 12-19. doi: 10.1016/j.bbr. 2015.04.052

Dhaneshwar, S., Patel, V., Patil, D., and Meena, G. (2013). Studies on synthesis, stability, release and pharmacodynamic profile of a novel diacerein-thymol prodrug. Bioorg. Med. Chem. Lett. 23, 55-61. doi: 10.1016/j.bmcl.2012. 11.016

Diao, H., Zheng, P., Yu, B., He, J., Mao, X., Yu, J., et al. (2015). Effects of benzoic acid and thymol on growth performance and gut characteristics of weaned piglets. Asian Australas. J. Anim. Sci. 28, 827-839. doi: 10.5713/ajas.14. 0704

Didri, N., Dubreuil, L., and Pinkas, M. (1994). Activity of thymol, carvacrol, cinnamaldehyde and eugenol on oral bacteria. Pharm. Acta Helv. 69, 25-28. doi: 10.1016/0031-6865(94)90027-2

Dutta, D. D., Parimala, G., Devi, S. S., and Chakraborty, T. (2011). Effect of thymol on peripheral blood mononuclear cell PBMC and acute promyelotic cancer cell line HL-60. Chem. Biol. Interact. 193, 97-106. doi: 10.1016/j.cbi.2011.05.009
Duyckaerts, C., Delatour, B., and Potier, M. C. (2009). Classification and basic pathology of Alzheimer disease. Acta Neuropathol. 118, 5-36. doi: 10.1007/ s00401-009-0532-1

Ebashi, S. (1965). "The sarcoplasmic reticulum and excitation-contraction coupling," in Molecular Biology of Muscular Contraction, eds S. Ebashi, F. Oosawa, T. Sekine, and Y. Tonomula (Amsterdam: Igaku-shoin, Tokyo and Elsevier Publishing Co), 197-206.

El-Nekeety, A. A., Mohamed, S. R., Hathout, A. S., Hassan, N. S., Aly, S. E., and Abdel-Wahhab, M. A. (2011). Antioxidant properties of Thymus vulgaris oil against aflatoxin-induce oxidative stress in male rats. Toxicon 57, 984-991. doi: 10.1016/j.toxicon.2011.03.021

El-Sayed, E. M., Abd-Allah, A. R., Mansour, A. M., and El-Arabey, A. A. (2014). Thymol and carvacrol prevent cisplatin-induced nephrotoxicity by abrogation of oxidative stress, inflammation, and apoptosis in rats. J. Biochem. Mol. Toxicol. 29, 165-172. doi: 10.1002/jbt.21681

El-Sayed, E. S. M., Mansour, A. M., and Abdul-Hameed, M. S. (2016). Thymol and carvacrol prevent doxorubicin- induced cardiotoxicity by abrogation of oxidative stress, inflammation, and apoptosis in rats. J. Biochem. Mol. Toxicol. 30, 37-44. doi: 10.1002/jbt.21740

Engelbertz, J., Lechtenberg, M., Studt, L., Hensel, A., and Verspohl, E. J. (2012). Bioassay-guided fractionation of a thymol-deprived hydrophilic thyme extract and its antispasmodic effect. J. Ethnopharmacol. 141, 848-853. doi: 10.1016/j. jep.2012.03.025

Enomoto, S., Asano, R., Iwahori, Y., Narui, T., Okada, Y., Singab, B., et al. (2001). Hematological studies on black cumin oil from the seeds of Nigella sativa L. Biol. Pharm. Bull. 24, 307-310. doi: 10.1248/bpb.24.307

Fachini-Queiroz, F. C., Kummer, R., Estevao-Silva, C. F., Carvalho, M. D., Cunha, J. M., Grespan, R., et al. (2012). Effects of thymol and carvacrol, constituents of Thymus vulgaris L. essential oil, on the inflammatory response. Evid. Based Complement. Alternat. Med. 2012:657026. doi: 10.1155/2012/657026

Farinacci, M., Colitti, M., Sqorlon, S., and Stefanon, B. (2008). Immunomodulatory activity of plant residues on ovine neutrophils. Vet. Immunol. Immunopathol. 126, 54-63. doi: 10.1016/j.vetimm.2008.06.006

Feldmann, M. (2002). Development of anti-TNF therapy for rheumatoid arthritis. Nat. Rev. Immunol. 2, 364-371. doi: 10.1038/nri802

Feldmann, M., Brennan, F. M., and Maini, R. N. (1996). Rheumatoid arthritis. Cell 85, 307-310. doi: 10.1016/S0092-8674(00)81109-5

Gao, S., and Singh, J. (1998). In vitro percutaneous absorption enhancement of a lipophilic drug tamoxifen by terpenes. J. Control. Release 51, 193-199. doi: 10.1016/S0168-3659(97)00168-5

Garcia, D. A., Bujons, J., Vale, C., and Sunol, C. (2006). Allosteric positive interaction of thymol with the GABAA receptor in primary cultures of mouse cortical neurons. Neuropharmacology 50, 25-35. doi: 10.1016/j.neuropharm. 2005.07.009

Gavliakova, S., Biringerova, Z., Buday, T., Brozmanova, M., Calkovsky, V., Poliacek, I., et al. (2013). Antitussive effects of nasal thymol challenges in healthy volunteers. Respir. Physiol. Neurobiol. 187, 104-107. doi: 10.1016/j.resp. 2013.02.011

Gholijani, N., and Amirghofran, Z. (2016). Effects of thymol and carvacrol on T-helper cell subset cytokines and their main transcription factors in ovalbumin-immunized mice. J. Immunotoxicol. 13, 729-737. doi: 10.3109/ 1547691X.2016.1173134

Gholijani, N., Gharagozloo, M., Farjadian, S., and Amirghofran, Z. (2016). Modulatory effects of thymol and carvacrol on inflammatory transcription factors in lipopolysaccharide-treated macrophages. J. Immunotoxicol. 13, 157164. doi: 10.3109/1547691X.2015.1029145

Gholijani, N., Gharagozloo, M., Kalantar, F., Ramezani, A., and Amirghofran, Z. (2015). Modulation of cytokine production and transcription factor activities in human Jurkat T-cells by thymol and carvacrol. Adv. Pharm. Bull. 5, 635-660. doi: 10.15171/apb.2015.089

Ghosheh, O. A., Houdi, A. A., and Crooks, P. A. (1999). High performance liquid chromatographic analysis of the pharmacologically active quinones and related compounds in the oil of the black seed (Nigella sativa L). J. Pharm. Biomed. Anal. 19, 757-762. doi: 10.1016/S0731-7085(98)00300-8

Giannenas, I., Triantafillou, E., Stavrakakis, S., Margaroni, M., Mavridis, S., Steiner, T., et al. (2012). Assessment of dietary supplementation with carvacrol or thymol containing feed additives on performance, intestinal microbiota and 
antioxidant status of rainbow trout (Oncorhynchus mykiss). Aquaculture 350, 26-32. doi: 10.1016/j.aquaculture.2012.04.027

Haeseler, G., Maue, D., Grosskreutz, J., Bufler, J., Nentwig, B., Piepenbrock, S., et al. (2002). Voltage dependent block of neuronal and skeletal muscle sodium channels by thymol and menthol. Eur. J. Anaesthesiol. 19, 571-579. doi: 10.1017/S0265021502000923

Haque, M. R., Ansari, S. H., Najmi, A. K., and Ahmad, M. A. (2014). Monoterpene phenolic compound thymol prevents high fat diet induced obesity in murine model. Toxicol. Mech. Methods 24, 116-123. doi: 10.3109/15376516.2013. 861888

Hasegawa, R., Nakaji, Y., Kurokawa, Y., and Tobe, M. (1989). Acute toxicity tests on 113 environmental chemicals. Sci. Rep. Res. Inst. Tohoku Univ. Med. 36, 10-16.

Hashemipour, H., Kermanshahi, H., Golian, A., and Veldkamp, T. (2013). Effect of thymol and carvacrol feed supplementation on performance, antioxidant enzyme activities, fatty acid composition, digestive enzyme activities, and immune response in broiler chickens. Poult. Sci. 92, 2059-2069. doi: 10.3382/ ps.2012-02685

He, L., Mo, H., Hadisusilo, S., Qureshi, A. A., and Elson, C. E. (1997). Isoprenoids suppress the growth of murine B16 melanomas in vitro and in vivo. J. Nutr. 127, 668-674.

Hejazian, S. H. (2006). Analgesic Effect of essential oil (EO) from Carum copticum in mice. World J. Med. Sci. 1, 95-99.

Hejazian, S. H., Bagheri, S. M., and Safari, F. (2014). Spasmolytic and antispasmodic action of Trachyspermum ammi essence on rat's ileum contraction. N. Am. J. Med. Sci. 6, 643-647. doi: 10.4103/1947-2714.147982

Hernandez, F., Madrid, J., Garcia, V., Orengo, J., and Megias, M. D. (2004). Influence of two plant extracts on broiler performance, digestibility, and digestive organ size. Poult. Sci. 83, 169-174. doi: 10.1093/ps/83.2.169

Hirobe, C., Qiao, Z. S., Takeya, K., and Itokawa, H. (1998). Cytotoxic principles from Majorana syriaca. Nat. Med. 52, 74-77.

Hisayama, T., and Takayanagi, I. (1986). Some properties and mechanisms of thymol-induced release of calcium from the calcium-store in guineapig taenia caecum. Jpn. J. Pharmacol. 40, 69-82. doi: 10.1254/jjp.40.69

Holmberg, K., and Hansen, B. (1979). Ester synthesis with dicyclohexylcarbodiimide improved by acid catalysts. Acta Chem. Scand. B 33, 410-412. doi: 10.3891/acta.chem.scand.33b-0410

Horvathova, E., Navarova, J., Galova, E., Sevcovicova, A., Chodakova, L., Snahnicanova, Z., et al. (2014). Assessment of antioxidative, chelating, and DNA-protective effects of selected essential oil components (eugenol, carvacrol, thymol, borneol, eucalyptol) of plants and intact Rosmarinus officinalis oil. J. Agric. Food Chem. 62, 6632-6639. doi: 10.1021/jf501006y

Horvathova, E., Turcaniova, V., and Slamenova, D. (2007). Comparative study of DNA-damaging and DNA protective effects of selected components of essential plant oils in human leukemic cells K562. Neoplasma 54, 478-483.

Hosseinimehr, S. J., Asadian, R., Naghshvar, F., Azizi, S., Jafarinejad, M., Noaparast, Z., et al. (2015). Protective effects of thymol against nephrotoxicity induced by cisplatin with using 99mTc-DMSA in mice. Ren. Fail. 37, 280-284. doi: 10.3109/0886022X.2014.991998

Hsu, S. S., Lin, K. L., Chou, C. T., Chiang, A. J., Liang, W. Z., and Chang, H. T. (2011). Effect of thymol on Ca2+ homeostasis and viability in human glioblastoma cells. Eur. J. Pharmacol. 670, 85-91. doi: 10.1016/j.ejphar.2011. 08.017

Hyun, T. K., Kim, H. C., and Kim, J. S. (2014). Antioxidant and antidiabetic activity of Thymus quinquecostatus Celak. Ind. Crops Prod. 52, 611-616. doi: 10.1016/j.indcrop.2013.11.039

Instituto Superiore di Sanita (1999). Up to Date Review of Toxicological Data of Some Plant Volatiles with Antifungal Activity. NTIS Report No PB2000106327. Rome: Instituto Superiore di Sanita.

Ito, Y., and Kuriyama, H. (1974). Effects of thymol on the electrical and mechanical properties of the guinea-pig taenia coli. J. Physiol. 236, 143-157. doi: 10.1113/ jphysiol.1974.sp010427

Jaafari, A., Tilaoui, M., Mouse, H. A., Ait M’bark, L., Aboufatima, R., Chait, A., et al. (2012). Comparative study of the antitumor effect of natural monoterpenes: relationship to cell cycle analysis. Braz. J. Pharmacog. 22, 534-540. doi: 10.1590/ s0102-695x2012005000021

Janbaz, K. H., Saeed, S. A., and Gilani, A. H. (2003). Hepatoprotective effect of thymol on chemical- induced hepatotoxicity in rodents. Pak. J. Biol. Sci. 2003, $448-451$.
Jang, I. S., Ko, Y. H., Kang, S. Y., and Lee, C. Y. (2007). Effect of commercial essential oils on growth performance, digestive enzyme activity and intestinal microflora population in broiler chickens. Anim. Feed Sci. Technol. 134, 304-315. doi: 10.1016/j.anifeedsci.2006.06.009

Jenner, P. M., Hagan, E. C., Taylor, J. M., Cook, E. L., Fitzhugh, O. G., Jenner, P., et al. (1964). Food flavourings and compounds of related structure I. Acute oral toxicity. Food Cosmet. Toxicol. 2, 327-343. doi: 10.1016/S0015-6264(64) 80192-9

Jeusette, I. C., Lhoest, E. T., Istasse, L. P., and Diez, M. O. (2005). Influence of obesity on plasma lipid and lipoprotein concentrations in dogs. Am. J. Vet. Res. 66, 81-86. doi: 10.2460/ajvr.2005.66.81

Jimenez, J., Navarro, M. C., Montilla, M. P., and Martin, A. (1993). Thymus zygis oil: Its effects on $\mathrm{CCl} 4$ induced hepatotoxicity and free radical scavenger activity. J. Essent. Oil Res. 5, 153-158.

Jordan, W., Van Barneveld, H., Gerlich, O., Kleine-Boymann, M., and Ullrich, J. (1991). "Phenol," in Ullmanns Encyclopedia of Industrial Chemistry, 5th Edn, Vol. A 19, eds B. Elvers, S. Hawkins, and G. Schulz (Weinheim: Wiley-VCH Verlag GmbH \& Co. KGaA), 299-312.

Juan, R. A., Olga, P. A., and Mirian, P. P. (2015). Chemical composition and anti-trypanosoma cruzi effect of Thymus vulgaris L. (thyme) essential oil and its main component, thymol, in mice. Am. J. Pharm. Pharmacol. 2, 21-27.

Jukic, M., Politeo, O., Maksimovic, M., and Milos, M. (2007). In vitro acetylcholinesterase inhibitory properties of thymol, carvacrol and their derivatives thymoquinone and thymohydroquinone. Phytother Res. 21, 259-261. doi: 10.1002/ptr.2063

Kabouche, A., Ghannadi, A., and Kabouche, Z. (2009). Thymus ciliates-the highest thymol containing essential oil of the genus. Nat. Prod. Commun. 4, 1251-1252.

Kamataki, T., Sugita, O., Naminohira, S., and Kitagawa, H. (1978). Effects of various compounds on lipid peroxidation mediated by detergent-solubilized rat liver NADPH-cytochrome C reductase. Jpn. J. Pharmacol. 28, 837-845. doi: $10.1254 /$ jjp.28.837

Kang, S. H., Kim, Y. S., Kim, E. K., Hwang, J. W., Jeong, J. H., Dong, X., et al. (2016). Anticancer effect of thymol on AGS human gastric carcinoma cells. J. Microbiol. Biotechnol. 26, 28-37. doi: 10.4014/jmb.1506.06073

Karpanen, T. J., Worthington, T., Hendry, E. R., Conway, B. R., and Lambert, P. A. (2008). Antimicrobial efficacy of chlorhexidine digluconate alone and in combination with eucalyptus oil, tea tree oil and thymol against planktonic and biofilm cultures of Staphylococcus epidermidis. J. Antimicrob. Chemother. 62, 1031-1036. doi: 10.1093/jac/dkn325

Kavoosi, G., Dadfar, S. M. M., and Purfard, A. M. (2013). Mechanical, physical, antioxidant, and antimicrobial properties of gelatin films incorporated with thymol for potential use as nano wound dressing. J. Food Sci. 78, E244-E250. doi: 10.1111/1750-3841.12015

Kavoosi, G., and Teixeira da Silva, J. A. (2012). Inhibitory effects of Zataria multiflora essential oil and its main components on nitric oxide and hydrogen peroxide production in glucose- stimulated human monocyte. Food Chem. Toxicol. 50, 3079-3085. doi: 10.1016/j.fct.2012.06.002

Kavoosi, G., Teixeira da Silva, J. A., and Saharkhiz, M. J. (2012). Inhibitory effects of Zataria multiflora essential oil and its main components on nitric oxide and hydrogen peroxide production in lipopolysaccharide stimulated macrophages. J. Pharm. Pharmacol. 64, 1491-1500. doi: 10.1111/j.2042-7158.2012. 01510.x

Kawasaki, H., Mizuta, K., Fujita, T., and Kumamoto, E. (2013). Inhibition by menthol and its related chemicals of compound action potentials in frog sciatic nerves. Life Sci. 92, 359-367. doi: 10.1016/j.lfs.2013.01.012

Khadir, A., Sobeh, M., Gad, H. A., Benbelaid, F., Bendahou, M., Peixoto, H., et al. (2016). Chemical composition and biological activity of the essential oil from Thymus lanceolatus. Z. Naturforsch. 71, 155-163. doi: 10.1515/znc-20160005

Khajeali, Y., Kheiri, F., Rahimian, Y., Faghani, M., and Namjo, A. (2012). Effect of use different levels of caraway (Carum carvi L.) powder on performance, some blood parameters and intestinal morphology on broiler chickens. World Appl. Sci. J. 19, 1202-1207.

Khajeh, M., Yamini, Y., Sefidkon, F., and Bahramifar, N. (2004). Comparison of essential oil composition of Carum copticum obtained by supercritical carbon dioxide extraction and hydrodistillation methods. Food Chem. 86, 587-591. doi: 10.1016/j.foodchem.2003.09.041 
Khan, S. T., Khan, M., Ahmad, J., Wahab, R., Abd-Elkader, O. H., Musarrat, J., et al. (2017). Thymol and carvacrol induce autolysis, stress, growth inhibition and reduce the biofilm formation by Streptococcus mutans. AMB Express 7, 49. doi: 10.1186/s13568-017-0344-y

Khosravi, A. R., and Erle, D. J. (2016). Chitin-induced airway epithelial cell innate immune responses are inhibited by carvacrol/thymol. PLoS ONE 11:e0159459. doi: 10.1371/journal.pone.0159459

Kim, Y. S., Hwang, J. W., Kang, S. H., Kim, E. H., Jeon, Y. J., Jeong, J. H., et al. (2014). Thymol from Thymus quinquecostatus Celak. protects against tertbutyl hydroperoxide- induced oxidative stress in Chang cells. J. Nat. Med. 68, 154-162. doi: 10.1007/s11418-013-0786-8

Kishwar, F., Mahmood, I., Mahmood, T., and Ul-Haq, Q. (2013). Thymol, an active constituent of Nigella sativa, could reduce toxicity of some trace metals (Fe(III), Cr(VI),Cu(II), V(IV) and $\mathrm{Co}(\mathrm{II})$ ). Eur. Academ. Res. 1, 1110-1125.

Kohlert, C., Schindler, G., Marz, R. W., Abel, G., Brinkhaus, B., Derendorf, H., et al. (2002). Systemic availability and pharmacokinetics of thymol in humans. J. Clin. Pharmacol. 42, 731-737. doi: 10.1177/009127002401102678

Kostyuk, P. G., Belan, P. V., and Tepikin, A. V. (1991). Free calcium transients and oscillations in nerve cells. Exp. Brain Res. 83, 459-464. doi: 10.1007/BF00231173

Kruk, I., Michalska, T., Lichszteld, K., Koadna, A., and Aboul-Enein, H. Y. (2000). The effect of thymol and its derivatives on reactions generating reactive oxygen species. Chemosphere 41, 1059-1064. doi: 10.1016/S0045-6535(99)00454-3

Ku, C. M., and Lin, J. Y. (2013). Anti-inflammatory effects of 27 selected terpenoid compounds tested through modulating Th1/Th2 cytokine secretion profiles using murine primary splenocytes. Food Chem. 141, 1104-1113. doi: 10.1016/j. foodchem.2013.04.044

Kundu, S., Shabir, H., Basir, S. F., and Khan, L. A. (2016). Thymol tempers As (III) and $\mathrm{Hg}$ (II) caused hypercontractility by similar pathways in isolated aortic and tracheal rings. Int. J. Pharm. Pharmaceut. Sci. 8, 404-407.

Lazar, M. A. (2005). How obesity causes diabetes: not a tall tale. Science 307, 373-375. doi: 10.1126/science.1104342

Lee, B. H., Nam, T. G., Park, W. J., Kang, H., Heo, H. J., Chung, D. K., et al. (2015). Antioxidative and neuroprotective effects of volatile components in essential oils from Chrysanthemum indicum Linne flowers. Food Sci. Biotechnol. 24, 717-723. doi: 10.1007/s10068-015-0093-0

Lee, K. P., Kim, J. E., Park, W. H., and Hong, H. (2016). Regulation of C6 glioma cell migration by thymol. Oncol. Lett. 11, 2619-2624. doi: 10.3892/ol.2016.4237

Lee, S. P., Buber, M. T., Yang, Q., Cerne, R., Cortes, R. T., Sprous, D. G., et al. (2008). Thymol and related alkyl phenols activate the hTRPAl channel. Brit. J. Pharmacol. 153, 1739-1749. doi: 10.1038/bjp.2008.85

Li, S., Ru, Y., Liu, M., Xu, B., Peron, A., and Shi, X. (2012). The effect of essential oils on performance, immunity and gut microbial population in weaner pigs. Livest. Sci. 145, 119-123. doi: 10.1016/j.livsci.2012.01.005

Liang, D., Li, F., Fu, Y., Cao, Y., Song, X., Wang, T., et al. (2014). Thymol inhibits LPS- Stimulated inflammatory response via down-regulation of NF- $\kappa B$ and MAPK signaling pathways in mouse mammary epithelial cells. Inflammation 37, 214-222. doi: 10.1007/s10753-013-9732-x

Liang, H., Bao, F., Dong, X., Tan, R., Zhang, C., Lu, Q., et al. (2007). Antibacterial thymol derivatives isolated from Centipeda minima. Molecules 12, 1606-1613. doi: $10.3390 / 12081606$

Lide, D. R., and Frederikse, H. P. R. (1996). CRC Handbook of Chemistry and Physics. Boca Raton, NY: CRC Press, 3-258.

Lorente, I., Ocete, M. A., Zarzuelo, A., Cabo, M. M., and Jimenez, J. (1989). Bioactivity of the essential oil of Bupleurum fruticosum. J. Nat. Prod. 52, 267-272. doi: 10.1021/np50062a008

Magyar, J., Szentandrassy, N., Banyasz, T., Fulop, L., Varro, A., and Nanasi, P. P. (2002). Effects of thymol on calcium and potassium currents in canine and human ventricular cardiomyocytes. Br. J. Pharmacol. 136, 330-338. doi: 10.1038/sj.bjp.0704718

Magyar, J., Szentandrassy, N., Banyasz, T., Fulop, L., Varro, A., and Nanasi, P. P. (2004). Effects of terpenoid phenol derivatives on calcium current in canine and human ventricular cardiomyocytes. Eur. J. Pharmacol. 487, 29-36. doi: 10.1016/j.ejphar.2004.01.011

Mahmoud, A. L. (1994). Antifungal action and antiaflatoxigenic properties of some essential oil constituents. Lett. Appl. Microbiol. 19, 110-113. doi: 10.1111/j. 1472-765X.1994.tb00918.x
Maisanaba, S., Prieto, A. I., Puerto, M., Gutierrez-Praena, D., Demir, E., Marcos, R., et al. (2015). In vitro genotoxicity testing of carvacrol and thymol using the micronucleus and mouse lymphoma assays. Mutat. Res. Genet. Toxicol. Environ. Mutagen. 784, 37-44. doi: 10.1016/j.mrgentox.2015. 05.005

Manabe, A., Nakayama, S., and Sakamoto, K. (1987). Effects of essential oils on erythrocytes and hepatocytes from rats and dipalmitoyl phosphatidylcholineliposomes. Jpn. J. Pharmacol. 44, 77-84. doi: 10.1254/jjp.44.77

Manou, I., Bouillard, L., Devleeschouwer, M. J., and Barel, A. O. (1998). Evaluation of the preservation properties of Thymus vulgaris essential oil in applied formulations under a challenge test. J. Appl. Microbiol. 84, 368-376. doi: 10. 1046/j.1365-2672.1998.00353.x

Marchese, A., Orhan, I. E., Daglia, M., Barbieri, R., Di Lorenzo, A., and Nabavi, S. F. (2016). Antibacterial and antifungal activities of thymol: A brief review of the literature. Food Chem. 210, 402-414. doi: 10.1016/j.foodchem.2016. 04.111

Marin, L. D., Sanchez-Borzone, M., and Garcia, D. A. (2011). Comparative antioxidant properties of some gabaergic phenols and related compounds, determined for homogeneous and membrane systems. Med. Chem. 7, 317-324. doi: $10.2174 / 157340611796150969$

Marino, M., Bersani, C., and Comi, G. (1999). Antimicrobial activity of the essential oils of Thymus vulgaris L. measured using a bioimpedometric method. J. Food Prot. 62, 1017-1023. doi: 10.4315/0362-028X-62.9.1017

Markovic, P., Chatzopoulou, P., Siljegovic, J., Nikolic, M., Glamoclija, J., Ciric, A., et al. (2011). Chemical analysis and antimicrobial activities of the essential oils of Satureja thymbra L. and Thymbra spicata L. and their main components. Arch. Biol. Sci. 63, 457-464. doi: 10.2298/ABS1102457M

Marsik, P., Kokoska, L., Landa, P., Nepovim, A., Soudek, P., and Vanek, T. (2005). In vitro inhibitory effects of thymol and quinones of Nigella sativa seeds on cyclooxygenase-1- and -2-catalyzed prostaglandin E2 biosyntheses. Planta Med. 71, 739-742. doi: 10.1055/s-2005-871288

Martins, I. M., Barreiro, M. F., Coelho, M., and Rodrigues, A. E. (2014). Microencapsulation ofessential oils with biodegradable polymeric carriers for cosmetic applications. Chem. Eng. J. 245, 191-200. doi: 10.1016/j.cej.2014. 02.024

Maruniak, J., Clark, W. B., Walker, C. B., Magnusson, I., Marks, R. G., Taylor, M., et al. (1992). The effect of 3 mouthrinses on plaque and gingivitis development. J. Clin. Periodontol. 19, 19-23. doi: 10.1111/j.1600-051X.1992.tb01143.x

Mastelic, J., Jerkovic, I., Blazevic, I., Poljak-Blazi, M., Borovic, S., Ivancic Bace, I., et al. (2008). Comparative study on the antioxidant and biological activities of carvacrol, thymol, and eugenol derivatives. J. Agric. Food Chem. 56, 3989-3996. doi: 10.1021/jf073272v

Mathela, C. S., Singh, K. K., and Gupta, V. K. (2010). Synthesis and in vitro antibacterial activity of thymol and carvacrol derivatives. Acta Pol. Pharm. 67, 375-380.

Meister, A., Bernhardt, G., Christoffel, V., and Buschauer, A. (1999). Antispasmodic activity of Thymus vulgaris extract on the isolated guineapig trachea: discrimination between drug and ethanol effects. Planta Med. 65, 512-516. doi: 10.1055/s-1999- 14006

Melo, J. O., Fachin, A. L., Rizo, W. F., Jesus, H. C., Arrigoni-Blank, M. F., Alves, P. B., et al. (2014). Cytotoxic effects of essential oils from three Lippia gracilis Schauer genotypes on HeLa, B16, and MCF-7 cells and normal human fibroblasts. Gen. Mol. Res. 13, 2691-2697. doi: 10.4238/2014.April.8.12

Mendes, S. S., Bomfim, R. R., Jesus, H. C., Alves, P. B., Blank, A. F., Estevam, C. S., et al. (2010). Evaluation of the analgesic and anti-inflammatory effects of the essential oil of Lippia gracilis leaves. J. Ethnopharmacol. 129, 391-397. doi: 10.1016/j.jep.2010.04.005

Mezzoug, N., Elhadri, A., Dallouh, A., Amkiss, S., Skali, N. S., Abrini, J., et al. (2007). Investigation of the mutagenic and antimutagenic effects of Origanum compactum essential oil and some of its constituents. Mutat. Res. 629, 100-110. doi: 10.1016/j.mrgentox.2007.01.011

Michiels, J., Missotten, J., Dierick, N., Fremaut, D., Maene, P., and De Smet, S. (2008). In vitro degradation and in vivo passage kinetics of carvacrol, thymol, eugenol and trans- cinnamaldehyde along the gastrointestinal tract of piglets. J. Sci. Food Agric. 88, 2371-2381. doi: 10.1002/jsfa.3358

Miguel, M. G., Gago, C., Antunes, M. D., Megias, C., Cortes-Giraldo, I., Vioque, J., et al. (2015). Antioxidant and antiproliferative activities of the essential oils 
from Thymbra capitata and thymus species grown in portugal. Evid. Based Complement. Alternat. Med. 2015:851721. doi: 10.1155/2015/851721

Miller, A. H., and Timmie, W. P. (2009). Mechanisms of cytokine induced behavioral changes: psychoneuroimmunology at the translational interface. Brain Behav. Immun. 23, 149-158. doi: 10.1016/j.bbi.2008.08.006

Mishra, R. K., and Baker, M. T. (2014). Seizure prevention by the naturally occurring phenols, carvacrol and thymol in a partial seizure-psychomotor model. Bioorg. Med. Chem. Lett. 24, 5446-5449. doi: 10.1016/j.bmcl.2014.10.028

Mohammadi, B., Haeseler, G., Leuwer, M., Dengler, R., Krampfl, K., and Bufler, J. (2001). Structural requirements of phenol derivatives for direct activation of chloride currents via GABA(A) receptors. Eur. J. Pharmacol. 421, 85-91. doi: 10.1016/S0014-2999(01)01033-0

Moller, H. (1939). Effect of thymol on thyroid gland. Arch. Exp. Pathol. Pharmak. 191, 615-620.

Monteiro, M. V., de Melo Leite, A. K., Bertini, L. M., de Morais, S. M., and Nunes-Pinheiro, D. C. (2007). Topical anti-inflammatory, gastroprotective and antioxidants effects of the essential oil of Lippia sidoides Cham. leaves. J. Ethnopharmacol. 111, 378-382. doi: 10.1016/j.jep.2006.11.036

Mottawie, H., Ibrahiem, A., and Amer, H. (2011). Role of some phytochemicals in the treatment of bronchial asthma. Med. J. Cairo Univ. 79, 75-80.

Nagle, P. S., Pawar, Y. A., Sonawane, A. E., Nikum, A. P., and Patil, U. D. (2013). Thymol: synthesis, reactions \& its spectrum of pharmacological and chemical applications. Indo. Am. J. Pharm. Res. 3, 7549-7561.

Nagoor Meeran, M. F., Jagadeesh, G. S., and Selvaraj, P. (2014). Protective efficacy of thymol on glycoproteins in isoproterenol induced myocardial infarcted rats: an in vivo and in vitro study. Int. J. Pharmaceut. Biol. Arch. 5, 168-173. doi: $10.1002 / \mathrm{jbt} .21431$

Nagoor Meeran, M. F., Jagadeesh, G. S., and Selvaraj, P. (2015a). Catecholamine toxicity triggers myocardial membrane destabilization in rats: thymol and its counter action. RSC Adv. 5, 43338-43344. doi: 10.1016/j.ejphar.2016.02.063

Nagoor Meeran, M. F., Jagadeesh, G. S., and Selvaraj, P. (2015b). Thymol attenuates altered lipid metabolism in $\beta$ adrenergic agonist induced myocardial infarcted rats by inhibiting tachycardia, altered electrocardiogram, apoptosis and cardiac hypertrophy. J. Funct. Foods 14, 51-62. doi: 10.1016/j.jff.2015.01.013

Nagoor Meeran, M. F., Jagadeesh, G. S., and Selvaraj, P. (2015c). Thymol attenuates inflammation in isoproterenol induced myocardial infarcted rats by inhibiting the release of lysosome enzymes and downregulating the expressions of proinflammatory cytokines. Eur. J. Pharmacol. 753, 153-161. doi: 10.1016/j. ejphar.2015.02.028

Nagoor Meeran, M. F., Jagadeesh, G. S., and Selvaraj, P. (2016a). Synthetic catecholamine triggers $\beta 1$-adrenergic receptor activation and stimulates cardiotoxicity via oxidative stress mediated apoptotic cell death in rats: abrogating action of thymol. Chem. Biol. Interact. 251, 17-25. doi: 10.1016/j. cbi.2016.03.017

Nagoor Meeran, M. F., Jagadeesh, G. S., and Selvaraj, P. (2016b). Thymol, a dietary monoterpene phenol abrogates mitochondrial dysfunction in $\beta$-adrenergic agonist induced myocardial infarcted rats by inhibiting oxidative stress. Chem. Biol. Interact. 244, 159-168. doi: 10.1016/j.cbi.2015.12.006

Nagoor Meeran, M. F., and Prince, P. S. (2012). Protective effects of thymol on altered plasma lipid peroxidation and nonenzymic antioxidants in isoproterenol- induced myocardial infarcted rats. J. Biochem. Mol. Toxicol. 26, 368-373. doi: $10.1002 /$ jbt. 21431

Nayak, B. S., Ghosh, S. K., and Patro, K. T. B. (2009). Preparation and characterization of famotidine microcapsule employing mucoadhesive polymers combination to enhance gastero retention for oral delivery. Int. J. Pharm. Pharm. Sci. 1, 112-120.

Nieddu, M., Rassu, G., Boatto, G., Bosi, P., Trevisi, P., Giunchedi, P., et al. (2014). Improvement of thymol properties by complexation with cyclodextrins: In vitro and in vivo studies. Carbohyd. Polym. 102, 393-399. doi: 10.1016/j.carbpol.2013. 10.084

Norwitz, G., Nataro, N., and Keliher, P. N. (1986). Study of the steam distillation of phenolic compounds using ultraviolet spectrometry. Anal. Chem. 58, 639-641. doi: 10.1021/ac00294a034

O’Brien, T. J., Ceryak, S., and Patierno, S. R. (2003). Complexities of chromium carcinogenesis: role of cellular response, repair and recovery mechanisms. Mutat. Res. 533, 3-36. doi: 10.1016/j.mrfmmm.2003.09.006
Ocana, A., and Reglero, G. (2012). Effects of thyme extract oils (from Thymus vulgaris, Thymus zygis, and Thymus hyemalis) on Cytokine production and gene expression of ox LDL- stimulated THP-1-macrophages. J. Obes. 11:104706. doi: $10.1155 / 2012 / 104706$

Ocana-Fuentes, A., Arranz-Gutierrez, E., Senorans, F. J., and Reglero, G. (2010). Supercritical fluid extraction of oregano (Origanum vulgare) essentials oils: anti-inflammatory properties based on cytokine response on THP-1 macrophages. Food Chem. Toxicol. 48, 1568-1575. doi: 10.1016/j.fct.2010. 03.026

Ogaard, B., Larsson, E., Glans, R., Henriksson, T., and Birkhed, D. (1997). Antimicrobial effect of a chlorhexidine-thymol varnish (Cervitec) in orthodontic patients. A prospective, randomized clinical trial. J. Orofac. Orthop. 58, 206-213.

Ogata, N., Matsushima, N., and Shibata, T. (1995). Pharmacokinetics of wood creosote: glucuronic acid and sulfate conjugation of phenolic compounds. Pharmacology 51, 195-204. doi: 10.1159/000139335

Oguri, A., Suda, M., Totsuka, Y., Sugimura, T., and Wakabayashi, K. (1998). Inhibitory effects of antioxidants on formation of heterocyclic amines. Mutat. Res. 402, 237-245. doi: 10.1016/S0027-5107(97)00303-5

Olasupo, N., Fitzgerald, D., Gasson, M., and Narbad, A. (2003). Activity of natural antimicrobial compounds against Escherichia coli and Salmonella enterica sero var. typhimurium. Lett. Appl. Microbiol. 37, 448-451. doi: 10.1046/j.1472-765X. 2003.01427.x

Ozen, T., Demirtas, I., and Aksit, H. (2011). Determination of antioxidant activities of various extracts and essential oil compositions of Thymus praecox subsp. skorpilii var. skorpilii. Food Chem. 124, 58-64. doi: 10.1016/j.foodchem.2010. 05.103

Ozkan, A., and Erdogan, A. A. (2011). Comparative evaluation of antioxidant and anticancer activity of essential oil from Origanum onites (Lamiaceae) and its two major phenolic components. Turk. J. Biol. 35, 735-742.

Ozkan, A., and Erdogan, A. A. (2012). Comparative study of the antioxidant/ prooxidant effects of carvacrol and thymol at various concentrations on membrane and DNA of parental and drug resistant H1299 cells. Nat. Prod. Commun. 7, 1557-1560.

Ozolua, R. I., Umuso, D. I., Uwaya, D. O., Modugu, A. A., Oghuvwu, S. O., and Olomu, J. M. (2016). Evaluation of the anti-asthmatic and antitussive effects of aqueous leaf extract of Ocimum gratissimum in rodents. Med. Aromat. Plants 5, 2.

Palabiyik, S. S., Karakus, E., Halici, Z., Cadirci, E., Bayir, Y., Ayaz, G., et al. (2016). The protective effects of carvacrol and thymol against paracetamol- induced toxicity on human hepatocellular carcinoma cell lines (HepG2). Hum. Exp. Toxicol. 35, 1252-1263. doi: 10.1177/0960327115627688

Palaniappan, K., and Holley, R. A. (2010). Use of natural antimicrobials to increase antibiotic susceptibility of drug resistant bacteria. Int. J. Food Microbiol. 140, 164-168. doi: 10.1016/j.ijfoodmicro.2010.04.001

Pan, K., Chen, H., Davidson, P. M., and Zhong, Q. (2014). Thymol nanoencapsulated by sodium caseinate: physical and antilisterial properties. J. Agric. Food Chem. 62, 1649-1657. doi: 10.1021/jf4055402

Pandey, A. K., Singh, P., and Tripathi, N. N. (2014). Chemistry and bioactivities of essential oils of some Ocimum species: an overview. Asian Pac. J. Trop. Biomed. 4, 682-694. doi: 10.12980/APJTB.4.2014C77

Parasei, P., Bahmani, M., Naghdi, N., Asadi-Samani, M., and Rafieian-Kopaei, M. (2016). A review of therapeutic and pharmacological effects of thymol. Pharm. Lett. 8, 150-154.

Parker, D. A., Marino, V., and Ong, J. (2014). Pharmacological actions of thymol and an analogue at GABAB autoreceptors. Clin. Exp. Pharmacol. Physiol. 41, 623-627. doi: 10.1111/1440-1681.12278

Pathania, A. S., Guru, S. K., Verma, M. K., Sharma, C., Abdullah, S. T., Malik, F., et al. (2013). Disruption of the PI3K/AKT/mTOR signaling cascade and induction of apoptosis in HL-60 cells by an essential oil from Monarda citriodora. Food Chem. Toxicol. 62, 246-254. doi: 10.1016/j.fct.2013.08.037

Pavela, R. (2009). Larvicidal property of essential oils against Culex quinquefasciatus Say (Diptera: Culicidae). Ind. Crops Prod. 30, 311-315. doi: 10.1016/j.indcrop.2009.06.005

Pearson, D. A., Frankel, E. N., Aeschbach, R., and German, J. B. (1997). Inhibition of endothelial cell- mediated oxidation of low-density lipoprotein by rosemary and plant phenolics. J. Agric. Food Chem. 45, 578-582. doi: 10.1021/jf9603893 
Peixoto-Neves, D., Silva-Alves, K. S., Gomes, M. D., Lima, F. C., Lahlou, S., Magalhaes, P. J., et al. (2010). Vasorelaxant effects of the monoterpenic phenol isomers, carvacrol and thymol, on rat isolated aorta. Fund. Clin. Pharmacol. 24, 341-350. doi: 10.1111/j.1472-8206.2009.00768.x

Pemmaraju, S. C., Pruthi, P. A., Prasad, R., and Pruthi, V. (2013). Candida albicans biofilm inhibition by synergistic action of terpenes and fluconazole. Indian J. Exp. Biol. 51, 1032-1037.

Perez-Roses, R., Risco, E., Vila, R., Penalver, P., and Canigueral, S. (2016). Biological and non- biological antioxidant activity of some essential oils. J. Agric. Food Chem. 64, 4716-4724. doi: 10.1021/acs.jafc.6b00986

Platel, K., and Srinivasan, K. (2004). Digestive stimulant action of spices: a myth or reality? Indian J. Med. Res. 2004, 167-179.

Poulose, A. J., and Croteau, R. (1978). Biosynthesis of aromatic monoterpenes: conversion of $\gamma$ - terpinene to $\mathrm{p}$ - cymene and thymol in Thymus vulgaris L. Arch. Biochem. Biophys. 187, 307-314. doi: 10.1016/0003-9861(78) 90039-5

Priestley, C. M., Williamson, E. M., Wafford, K. A., and Sattelle, D. B. (2003). Thymol, a constituent of thyme essential oil, is a positive allosteric modulator of human GABA(A) receptors and a homo-oligomeric GABA receptor from Drosophila melanogaster. Br. J. Pharmacol. 140, 1363-1372. doi: 10.1038/sj.bjp. 0705542

Raddatz, D., Bockemuhl, M., and Ramadori, G. (2005). Quantitative measurement of cytokine mRNA in inflammatory bowel disease: relation to clinical and endoscopic activity and outcome. Eur. J. Gastroenterol. Hepatol. 17, 547-557. doi: 10.1097/00042737-200505000-00012

Rahmani, A. H., Al Zohairy, M. A., Aly, S. M., and Khan, M. A. (2014). Curcumin: a potential candidate in prevention of cancer via modulation of molecular pathways. Biomed. Res. Int. 2014:761608. doi: 10.1155/2014/76 1608

Raoof, A. A., van Obbergh, L. J., de Ville de Goyet, J., and Veerbeeck, R. K. (1996). Extrahepatic glucuronidation of propofol in man: possible contribution of gut wall and kidney. Eur. J. Clin. Pharmacol. 50, 91-96. doi: 10.1007/s002280050074

Raskovic, A., Pavlovic, N., Kvrgic, M., Sudji, J., Mitic, G., Capo, I., et al. (2015). Effects of pharmaceutical formulations containing thyme on carbon tetrachloride-induced liver injury in rats. BMC Complement. Altern. Med. 15:442. doi: 10.1186/s12906-015-0966-z

Rassu, G., Nieddu, M., Bosi, P., Trevisi, P., Colombo, M., Priori, D., et al. (2014). Encapsulation and modified-release of thymol from oral microparticles as adjuvant or substitute to current medications. Phytomedicine 21, 1627-1632. doi: 10.1016/j.phymed.2014.07.017

Reema, M. A. (2011). Cytotoxic, cytogenetics and immunomodulatory effects of thymol from Thymus vulgaris on cancer and normal cell lines in vitro and in vivo. Al-Mustansiriyah J. Sci. 22, 41-53.

Ribeiro, A. R., Diniz, P. B., Pinheiro, M. S., Albuquerque-Junior, R. L., and Thomazzi, S. M. (2016). Gastroprotective effects of thymol on acute and chronic ulcers in rats: the role of prostaglandins, ATP- sensitive $\mathrm{K}+$ channels, and gastric mucus secretion. Chem. Biol. Interact. 244, 121-128. doi: 10.1016/j.cbi. 2015.12.004

Riella, K. R., Marinho, R. R., Santos, J. S., Pereira-Filho, R. N., Cardoso, J. C., Albuquerque-Junior, R. L., et al. (2012). Anti-inflammatory and cicatrizing activities of thymol, a monoterpene of the essential oil from Lippia gracilis, in rodents. J. Ethnopharmacol. 143, 656-663. doi: 10.1016/j.jep.2012. 07.028

Rivas, L., McDonnell, M. J., Burgess, C. M., O’Brien, M., Navarro-Villa, A., Fanning, S., et al. (2010). Inhibition of verocytotoxigenic Escherichia coli in model broth and rumen systems by carvacrol and thymol. Int. J. Food Microbiol. 139, 70-78. doi: 10.1016/j.ijfoodmicro.2010.01.029

Robbins, B. H. (1934). Quantitative studies on the absorption and excretion of certain resorcinols and cresols in dogs and man. J. Pharmacol. Exp. Therapeut. $52,54-60$.

Robledo, S., Osorio, E., Munoz, D., Jaramillo, L. M., Restrepo, A., Arango, G., et al. (2005). In vitro and in vivo cytotoxicities and antileishmanial activities of thymol and hemisynthetic derivatives. Antimicrob. Agents Chemother. 49, 1652-1655. doi: 10.1128/AAC.49.4.1652-1655.2005

Rogerio, A. P., Dora, C. L., Andrade, E. L., Chaves, J. S., Silva, L. F., LemosSenna, E., et al. (2010). Anti- inflammatory effect of quercetin-loaded microemulsion in the airways allergic inflammatory model in mice. Pharmacol. Res. 61, 288-297. doi: 10.1016/j.phrs.2009.10.005
Rogler, G., and Andus, T. (1998). Cytokines in inflammatory bowel disease. World J. Surg. 22, 382-389. doi: 10.1007/s002689900401

Roost, M., Ghaedi, M., Daneshfar, A., and Sahraei, R. (2015). Ultrasound assisted microextraction- nano material solid phase dispersion for extraction and determination of thymol and carvacrolin pharmaceutical samples: experimental design methodology. J. Chromatogr. B Analyt. Technol. Biomed. Life Sci. 975, 34-39. doi: 10.1016/j.jchromb.2014.10.035

Rota, M. C., Herrera, A., Martinez, R. M., Sotomayor, J. A., and Jordàn, M. J. (2008). Antimicrobial activity and chemical composition of Thymus vulgaris, Thymus zygis and Thymus hyemalis essential oils. Food Control 19, 681-687. doi: 10.1016/j.foodcont.2007.07.007

Rustaiyan, A., Masoudi, S., Monfared, A., Kamalinejad, M., Lajevardi, T., Sedaghat, S., et al. (2000). Volatile constituents of three Thymus species grown wild in Iran. Planta Med. 66, 197-198. doi: 10.1055/s-0029-1243136

Sammi, S. R., Trivedi, S., Rath, S. K., Nagar, A., Tandon, S., Kalra, A., et al. (2016). 1-Methyl-4- propan-2-ylbenzene from Thymus vulgaris attenuates cholinergic dysfunction. Mol. Neurobiol. doi: 10.1007/s12035-016-0083-0 [Epub ahead of print].

Sancheti, J., Shaikh, M. F., Chaudhari, R., Somani, G., Patil, S., Jain, P., et al. (2014). Characterization of anticonvulsant and antiepileptogenic potential of thymol in various experimental models. Naunyn-Schmiedebergs Arch. Pharmacol. 387, 59-66. doi: 10.1007/s00210-013-0917-5

Sanchez, M. E., Turina, A. V., Garcia, D. A., Nolan, M. V., and Perillo, M. A. (2004). Surface activity of thymol: implications for an eventual pharmacological activity. Colloids Surf. B Biointerfaces 34, 77-86. doi: 10.1016/j.colsurfb.2003. 11.007

Sanchez-Castillo, C. P., Velasquez-Monroy, O., Lara-Esqueda, A., Berber, A., Sepulveda, J., Tapia-Conyer, R., et al. (2005). Diabetes and hypertension increases in a society with abdominal obesity: results of the Mexican National Health Survey. Public Health Nutr. 8, 53-60. doi: 10.1079/PHN2005659

Saravanan, S., and Pari, L. (2015). Role of thymol on hyperglycaemia and hyperlipidemia in high fat diet-induced type 2 diabetic C57BL/6J mice. Eur. J. Pharmacol. 761, 279-287. doi: 10.1016/j.ejphar.2015.05.034

Saravanan, S., and Pari, L. (2016). Protective effect of thymol on high fat diet induced diabetic nephropathy in C57BL/6J mice. Chem. Biol. Interact. 245, 1-11. doi: 10.1016/j.cbi.2015.11.033

Sarkozi, S., Almassy, J., Lukacs, B., Dobrosi, N., Nagy, G., and Jona, I. (2007). Effect of natural phenol derivatives on skeletal type sarcoplasmic reticulum Ca2+-ATPase and ryanodine receptor. J. Muscle Res. Cell Motil. 28, 167-174. doi: 10.1007/s10974-007-9113-x

Sasaki, K., Wada, K., Tanaka, Y., Yoshimura, T., Matuoka, K., and Anno, T. (2005). Thyme (Thymus vulgaris L.) leaves and its constituents increase the activities of xenobiotic- metabolizing enzymes in mouse liver. J. Med. Food. 8, 184-189. doi: $10.1089 /$ jmf.2005.8.184

Satooka, H., and Kubo, I. (2012). Effects of thymol on B16-F10 melanoma cells. J. Agric. Food Chem. 60, 2746-2752. doi: 10.1021/jf204525b

Schroder, V., and Vollmer, H. (1932). The excretion of thymol, carvacrol, eugenol and guiacoland the distribution of these substances in the organism. Arch. Exp. Pathol. Pharmak. 168, 331-353.

Sedova, L., Berube, J., Gaudet, D., Dumont, M., Tremblay, J., Hamet, P., et al. (2004). Diet- induced obesity delays cardiovascular recovery from stress in spontaneously hypertensive rats. Obes. Res. 12, 1951-1958. doi: 10.1038/oby. 2004.245

Seeman, P., Chen, S. S., Chau-Wong, M., and Staiman, A. (1974). Calcium reversal of nerve blockade by alcohols, anesthetics, tranquilizers, and barbiturates. Can. J. Physiol. Pharmacol. 52, 526-534. doi: 10.1139/y74-070

Shapiro, S., and Guggenheim, B. (1995). The action of thymol on oral bacteria. Oral Microbiol. Immunol. 10, 241-246. doi: 10.1111/j.1399-302X.1995.tb00149.x

Shapiro, S., Meier, A., and Guggenheim, B. (1994). The antimicrobiol activity of essential oils and essential oil components toward oral bacteria. Oral Microbiol. Immunol. 9, 202-208. doi: 10.1111/j.1399-302X.1994.tb00059.x

Shen, A. Y., Huang, M. H., Liao, L. F., and Wang, T. S. (2005). Thymol analogues with antioxidant and L-type calcium current inhibitory activity. Drug Dev. Res. 64, 195-202. doi: 10.1002/ddr.10436

Shettigar, N. B., Das, S., Rao, N. B., and Rao, S. B. (2015). Thymol, a monoterpene phenolic derivative of cymene, abrogates mercury-induced oxidative stress resultant cytotoxicity and genotoxicity in hepatocarcinoma cells. Environ. Toxicol. 30, 968-980. doi: 10.1002/tox.21971 
Shipkova, M., Strassburg, C. P., Braun, F., Streit, F., Grone, H. J., Armstrong, V. W., et al. (2001). Glucuronide and glucoside conjugation of mycophenolic acid by human liver, kidney and intestinal microsomes. Brit. J. Clin. Pharmacol. 132, 1027-1034. doi: 10.1038/sj.bjp.0703898

Singh, M. (1980). Amylase release from dissociated mouse pancreatic acinar cells stimulated by glucagon: effect of membrane stabilizers. J. Physiol. 309, 81-91. doi: 10.1113/jphysiol.1980.sp013495

Skold, K., Twetman, S., Hallgren, A., Yucel-Lindberg, T., and Modeer, T. (1998). Effect of a chlorhexidine/thymol- containing varnish on prostaglandin E2 levels in gingival crevicular fluid. Eur. J. Oral Sci. 106, 571-575. doi: 10.1046/j.09098836.1998.eos106106.x

Slamenova, D., Horvathova, E., Sramkova, M., and Marsalkova, L. (2007). DNAprotective effects of two components of essential plant oils carvacrol and thymol on mammalian cells cultured in vitro. Neoplasma 54, 108-112.

Sofowora, A., Ogunbodede, E., and Onayade, A. (2013). The role and place of medicinal plants in the strategies for disease prevention. Afr. J. Tradit. Complement. Altern. Med. 10, 210-229.

Soliman, K. M., and Badeaa, R. I. (2002). Effect of oil extracted from some medicinal plants on different mycotoxigenic fungi. Food Chem. Toxicol. 40, 1669-1675. doi: 10.1016/S0278-6915(02)00120-5

Soran, M. L., and Lung, I. (2010). HPTLC analysis of thymol in extracts of Satureja hortensis L. obtained by different techniques. J. Plan. Chromatogr. 23, 320-322. doi: 10.1556/JPC.23.2010.5.2

Stammati, A., Bonsi, P., Zucco, F., Moezelaar, R., Alakomi, H. L., and von Wright, A. (1999). Toxicity of selected plant volatiles in microbial and mammalian short-term assays. Food Chem. Toxicol. 37, 813-823. doi: 10.1016/ S0278-6915(99)00075-7

Stunkard, A. J., and Allison, K. C. (2003a). Binge eating disorder: disorder or marker. Int. J. Eat. Disord. 34, S107-S116.

Stunkard, A. J., and Allison, K. C. (2003b). Two forms of disordered eating inobesity: binge eating and night eating. Int. J. Obes. Relat. Metab. Disord. 27, $1-12$.

Stunkard, A. J., Faith, M. S., and Allison, K. C. (2003). Depression and obesity. Biol. Psychiatry 54, 330-335. doi: 10.1016/S0006-3223(03)00608-5

Surendra Kumar, M., Reddy, R., Manasa, G., Vanaja, P., Sirisha, G., and Astalakshmi, N. (2011). Antifertility effect of Trachyspermum ammi (Linn) sprague fruits on male rats. Int. J. Pharm. Biol. Arch. 2, 705-709.

Suzuki, Y., and Furuta, H. (1988). Stimulation of guinea pig neutrophil superoxide anion-producing system with thymol. Inflammation 12, 575-584. doi: 10.1007/ BF00914319

Suzuki, Y., Nakamura, S., Sugiyama, K., and Furuta, H. (1987). Differences of Superoxide production in blood leukocytes stimulated with thymol between human and non-human primates. Life Sci. 41, 1659-1664. doi: 10.1016/00243205(87)90735-1

Szentandrassy, N., Szentesi, P., Magyar, J., Nanasi, P. P., and Csernoch, L. (2003). Effect of thymol on kinetic properties of $\mathrm{Ca}$ and $\mathrm{K}$ currents in rat skeletal muscle. BMC Pharmacol. 3:9. doi: 10.1186/1471-2210-3-9

Szentandrassy, N., Szigeti, G., Szegedi, C., Sarkozi, S., Magyar, J., Banyasz, T., et al. (2004). Effect of thymol on calcium handling in mammalian ventricular myocardium. Life Sci. 74, 909-921. doi: 10.1016/j.lfs.2003.09.034

Szentesi, P., Szappanos, H., Szegedi, C., Gonczi, M., Jona, I., Cseri, J., et al. (2004). Altered elementary calcium release events and enhanced calcium release by thymol in rat skeletal muscle. Biophys. J. 86, 1436-1453. doi: 10.1016/S00063495(04)74213-7

Takada, M., Agata, I., Sakamoto, M., Yagi, N., and Hayashi, N. (1979). On the metabolic detoxication to thymol in rabbit and man. J. Toxicol. Sci. 4, 341-350. doi: $10.2131 /$ jts. 4.341

Takishima, K., Setaka, M., and Shimizu, H. (1979). On the overshoot of calcium accumulation in fragmented sarcoplasmic reticulum induced by thymol. J. Biochem. 86, 347-353. doi: 10.1093/oxfordjournals.jbchem. a132532

Tamura, T., and Iwamoto, H. (2004). Thymol: a classical small-molecule compound that has a dual effect (potentiating and inhibitory) on myosin. Biochem. Biophys. Res. Commun. 318, 786-791. doi: 10.1016/j.bbrc.2004.04.085

Taranu, I., Marin, D. E., Untea, A., Janczyk, P., Motiu, M., Criste, R. D., et al. (2012). Effect of dietary natural supplements on immune response and mineral bioavailability in piglets after weaning. Czech. J. Anim. Sci. 57, $332-343$.
Torres de Pinedo, A., Penalver, P., and Morales, J. C. (2007). Synthesis and evaluation of new phenolic-based antioxidants: structure-activity relationship. Food Chem. 103, 55-61. doi: 10.1016/j.foodchem.2006.07.026

Trevisi, P., Merialdi, G., Mazzoni, M., Casini, L., Tittarelli, C., De Filippi, S., et al. (2010). Effect of dietary addition of thymol on growth, salivary and gastric function immune response, and excretion of Salmonella enteric serovar Typhimurium, in weaning pigs challenged with this microbe strain. Ital. J. Anim. Sci. 6, 374-376. doi: 10.4081/ijas.2007.1s.374

Trombetta, D., Castelli, F., Sarpietro, M. G., Venuti, V., Cristani, M., Daniele, C., et al. (2005). Mechanisms of antibacterial action of three monoterpenes. Antimicrob. Agents Chemother. 49, 2474-2478. doi: 10.1128/AAC.49.6.24742478.2005

Tsai, M. L., Lin, C., Lin, W. C., and Yang, C. H. (2011). Antimicrobial, antioxidant and anti- inflammatory activities of essential oils from five selected herbs. Biosci. Biotechnol. Biochem. 75, 1977-1983. doi: 10.1271/bbb.110377

Turrin, N. P., and Rivest, S. (2004). Innate immune reaction in response to seizures: implications for the neuropathology associated with epilepsy. Neurobiol. Dis. 16, 321-324. doi: 10.1016/j.nbd.2004.03.010

Twetman, S., Hallgren, A., and Petersson, L. G. (1995). Effect of antibacterial varnish on mutant streptococci in plaque form enamel adjacent to orthodontic appliances. Caries Res. 29, 188-191. doi: 10.1159/000262067

Umar, S., Asif, M., Sajad, M., Ansari, M., Hussain, U., Ahmad, W., et al. (2012). Anti- inflammatory and antioxidant activity of Trachyspermum ammi seeds in collagen induced arthritis in rats. Int. J. Drug Dev. Res. 4, 210-219.

Undeger, U., Basaran, A., Degen, G. H., and Basaran, N. (2009). Antioxidant activities of major thyme ingredients and lack of (oxidative) DNA damage in V79 Chinese hamster lung fibroblast cells at low levels of carvacrol and thymol. Food Chem. Toxicol. 47, 2037-2043. doi: 10.1016/j.fct.2009. 05.020

Van den Broucke, C. O., and Lemli, J. A. (1980). Antispasmodic activity of Origanum compactum. Planta Med. 38, 317-331. doi: 10.1055/s-2008-1074884

Van den Broucke, C. O., and Lemli, J. A. (1982). Antispasmodic activity of Origanum compactum. Part 2: antagonistic effect of thymol and carvacrol. Planta Med. 45, 188-190. doi: 10.1055/s-2007-971371

Van den Hoven, R., Zappe, H., Zitterl-Eglseer, K., Jugl, M., and Franz, C. (2003). Study of the effect of Bronchipret on the lung function of five Austrian saddle horses suffering recurrent airway obstruction (heaves). Vet. Rec. 152, 555-557. doi: 10.1136/vr.152.18.555

Vardar-Unlu, G. V., Candan, F., Sokmen, A., Daferera, D., Pollissiou, M., Sokmen, M., et al. (2003). Antimicrobial and antioxidant activity of the essential oil and methanol extracts of Thymus pectinatus Fisch. et Mey. Var. pectinatus (Lamiaceae). J. Agric. Food Chem. 51, 63-67. doi: 10.1021/jf025753e

Venu, S., Naik, D. B., Sarkar, S. K., Usha, K., Aravind, U. K., Nijamudheen, A., et al. (2013). Oxidation reactions of thymol: a pulse radiolysis and theoretical study. J. Phys. Chem. A 117, 291-299. doi: 10.1021/jp3082358

Veras, H. N., Araruna, M. K., Costa, J. G., Coutinho, H. D., Kerntopf, M. R., Botelho, M. A., et al. (2013). Topical antiinflammatory activity of essential oil of Lippia sidoides Cham: possible mechanism of action. Phytother. Res. 27, 179-185. doi: 10.1002/ptr.4695

Viana, G. S. B., Matos, F. F., Araujo, W. L., Matos, F. J. A., and Craveiro, A. A. (1981). Essential oil of Lippia grata: pharmacological effects and main constituents. Quart. J. Crude Drug Res. 19, 1-10. doi: 10.3109/ 13880208109065203

Vigo, E., Cepeda, A., Gualillo, O., and Perez-Fernandez, R. (2004). In-vitro antiinflammatory effect of Eucalyptus globulus and Thymus vulgaris: nitric oxide inhibition in J774A.1 murine macrophages. J. Pharm. Pharmacol. 56, 257-263. doi: $10.1211 / 0022357022665$

Vila, R. (2002). "Flavonoids and further polyphenols in the genus Thymus," in Thyme: The Genus Thymus. Medicinal and Aromatic Plants-Industrial Profiles, eds E. Stahl-Biskup and F. Saez (New York, NY: Taylor and Francis), 75.

Wade, A., and Reynolds, J. E. F. (1997). Martindale-the Extra Pharmacopoeia. London: The Pharmaceutical Press, 536-537.

Wechsler, J. B., Hsu, C. L., and Bryce, P. J. (2014). IgE-mediated mast cell responses are inhibited by thymol-mediated, activation-induced cell death in skin inflammation. J. Allergy Clin. Immunol. 133, 1735-1743. doi: 10.1016/j.jaci. 2013.12.024

Wei, H. K., Xue, H. X., Zhou, Z. X., and Peng, J. (2016). A carvacrol-thymol blend decreased intestinal oxidative stress and influenced selected microbes 
without changing the messenger RNA levels of tight junction proteins in jejunal mucosa of weaning piglets. Animal 15, 1-9. doi: 10.1017/S175173111600 1397

Williams, R. T. (1959). Detoxication Mechanisms, 2nd Edn. London: Chapman and Hall, 300-301.

Wirtz, S., and Neurath, M. F. (2000). Animal models of intestinal inflammation: new insights into the molecular pathogenesis and immunotherapy of inflammatory bowel disease. Int. J. Colorectal. Dis. 15, 144-160. doi: 10.1007/ s003840000227

Wojdylo, A., Oszmianski, J., and Czemerys, R. (2007). Antioxidant activity and phenolic compounds in 32 selected herbs. Food Chem. 105, 940-949. doi: 10.1016/j.foodchem.2007.04.038

Xu, J., Zhou, F., Ji, B. P., Pei, R. S., and Xu, N. (2008). The antibacterial mechanism of carvacrol and thymol against Escherichia coli. Lett. Appl. Microbiol. 47, 174-179. doi: 10.1111/j.1472-765X.2008.02407.x

Xu, Z. H., Wang, C., Fujita, T., Jiang, C. Y., and Kumamoto, E. (2015). Action of thymol on spontaneous excitatory transmission in adult rat spinal substantia gelatinosa neurons. Neurosci. Lett. 606, 94-99. doi: 10.1016/j.neulet.2015.08.042

Yanishlieva, N. V., Marinovaa, E. M., Gordon, M. H., and Raneva, V. G. (1999). Antioxidant activity and mechanism of action of thymol and carvacrol in two lipid systems. Food Chem. 64, 59-66. doi: 10.1016/S0308-8146(98)00086-7

Yin, Q. H., Zhuang, Y. Z., and Yan, X. F. (2010). Antitumor efficacy of thymol. Prog. Mod. Biomed. 10, 2073-2075.

Youdim, K. A., and Deans, S. G. (1999). Beneficial effects of thyme oil on agerelated changes in the phospholipid C20 and C22 polyunsaturated fatty acid composition of various rat tissues. Biochim. Biophys. Acta 1438, 140-146. doi: 10.1016/S1388-1981(99)00045-1

Youdim, K. A., and Deans, S. G. (2000). Effect of thyme oil and thymol dietary supplementation on the antioxidant status and fatty acid composition of the ageing rat brain. Br. J. Nutr. 83, 87-93.

Yousefzadi, M., Riahi-Madvar, A., Hadian, J., Rezaee, F., and Rafiee, R. (2012). In vitro cytotoxic and antimicrobial activity of essential oil from Satureja sahendica. Toxicol. Environ. Chem. 94, 1735-1745. doi: 10.5812/ircmj.4989

Yu, Y. M., Chao, T. Y., Chang, W. C., Chang, M. J., and Lee, M. F. (2016). Thymol reduces oxidative stress, aortic intimal thickening, and inflammation-related gene expression in hyperlipidemic rabbits. J. Food Drug Anal. 24, 556-563. doi: $10.1016 /$ j.jfda.2016.02.004

Yucel-Lindberg, T., Twetman, S., Skold-Larsson, K., and Modeer, T. (1999). Effect of an antibacterial dental varnish on the levels of prostanoids, leukotriene B4, and interleukin-1 beta in gingival crevicular fluid. Acta Odontol. Scand. 57, 23-27. doi: 10.1080/000163599429066

Zahin, M., Ahmad, I., and Aqil, F. (2010). Antioxidant and antimutagenic activity of Carum copticum fruit extracts. Toxicol. In Vitro. 24, 1243-1249. doi: 10.1016/ j.tiv.2010.02.004
Zamani, Z., Alipour, D., Moghimi, H. R., Mortazavi, S. A., and Saffary, M. (2015). Development and evaluation of thymol microparticles using cellulose derivatives as controlled release dosage form. Iran J. Pharm. Res. 14, 1031-1040.

Zarzuelo, A., and Crespo, E. (2002). "The medicinal and non-medicinal uses of thyme," in Thyme: The Genus Thymus. Medicinal and Aromatic PlantsIndustrial Profiles, eds E. Stahl- Biskup and F. Saez (New York, NY: Taylor \& Francis), 263-292.

Zee, O. P., Jung, Y. H., Lee, K. R., Moon, H. I., Baek, H. G., Lee, M. J., et al. (2001). Thymol derivatives Having Anti Tumor Activity, and Anti-Cancer Agent Comprising the same. U. S. 6255517. Washington, DC: Patent and Trademark Office.

Zhang, Y., Niu, Y., Luo, Y., Ge, M., Yang, T., Yu, L. L., et al. (2014). Fabrication, characterization and antimicrobial activities of thymol-loaded zein nanoparticles stabilized by sodium caseinate-chitosan hydrochloride double layers. Food Chem. 142, 269-275. doi: 10.1016/j.foodchem.2013.07.058

Zheng, Z. L., Tan, J. Y. W., Liu, H. Y., Zhou, X. H., Xiang, X., and Wang, K. Y. (2009). Evaluation of oregano essential oil (Origanum heracleoticum L.) on growth, antioxidant effect and resistance against Aeromonas hydrophila in channel catfish (Ictalurus punctatus). Aquaculture 292, 214-218. doi: 10.1016/j. aquaculture.2009.04.025

Zhou, E., Fu, Y., Wei, Z., Yu, Y., Zhang, X., and Yang, Z. (2014). Thymol attenuates allergic airway inflammation in ovalbumin (OVA)-induced mouse asthma. Fitoterapia 96, 131-137. doi: 10.1016/j.fitote.2014.04.016

Zidan, D. E., Kahilo, K. A., El-Far, A., and Sadek, K. M. (2016). Ginger (Zingiber officinale) and thymol dietary supplementation improve the growth performance, immunity and antioxidant status in broilers. Glob. Vet. 16, $530-538$.

Conflict of Interest Statement: The authors declare that the research was conducted in the absence of any commercial or financial relationships that could be construed as a potential conflict of interest.

The reviewer FPG and handling Editor declared their shared affiliation, and the handling Editor states that the process nevertheless met the standards of a fair and objective review.

Copyright (C) 2017 Nagoor Meeran, Javed, Al Taee, Azimullah and Ojha. This is an open-access article distributed under the terms of the Creative Commons Attribution License (CC BY). The use, distribution or reproduction in other forums is permitted, provided the original author(s) or licensor are credited and that the original publication in this journal is cited, in accordance with accepted academic practice. No use, distribution or reproduction is permitted which does not comply with these terms. 